Portland State University

PDXScholar

$5-11-1981$

\title{
The Bungalow Aesthetic: the Social Implications of a Nationwide Phenomenon Viewed from the Perspective of a Small Town
}

Janice Williams Rutherford Portland State University

Follow this and additional works at: https://pdxscholar.library.pdx.edu/open_access_etds

Part of the Architectural History and Criticism Commons, and the United States History Commons Let us know how access to this document benefits you.

\section{Recommended Citation}

Rutherford, Janice Williams, "The Bungalow Aesthetic: the Social Implications of a Nationwide Phenomenon Viewed from the Perspective of a Small Town" (1981). Dissertations and Theses. Paper 3188.

https://doi.org/10.15760/etd.3179

This Thesis is brought to you for free and open access. It has been accepted for inclusion in Dissertations and Theses by an authorized administrator of PDXScholar. Please contact us if we can make this document more accessible: pdxscholar@pdx.edu. 
AN ABSTRACT OF THE THESIS OF Janice Williams Rutherford for the Master of Arts in History, presented on May 11, 1981.

Title: The Bungalow Aesthetic: The Social Implications of a Nationwide Phenomenon Viewed From the Perspective of a Small Town.

APPROVED BY MEMBERS OF THE THESIS COMMITTEE:

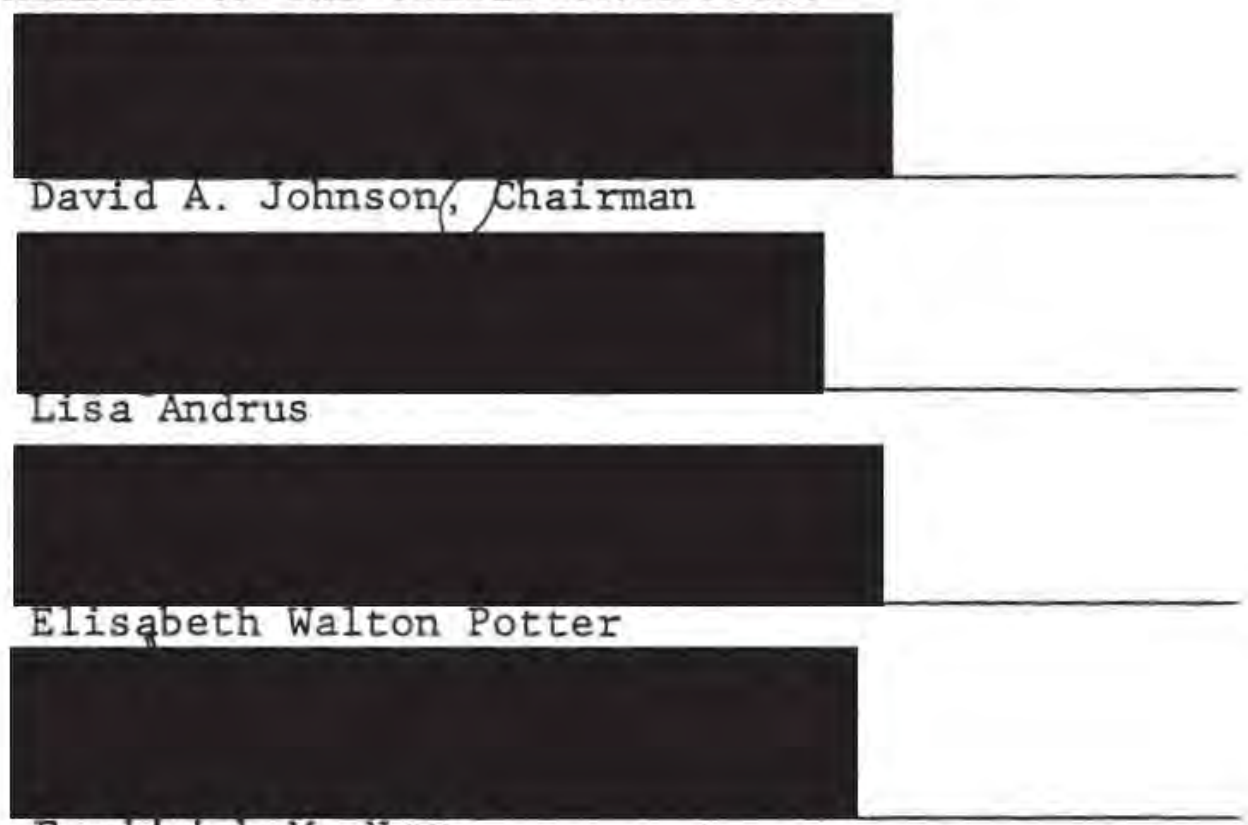

Frederick M. Nunn

During the first two decades of the twentieth century, a new aesthetic in the domestic architecture of middle-class America emerged. A new style of house, the bungalow, was introduced soon after the turn of the century, and within a very few years, became the most popular building style among Americans who were buying moderately-oriced homes. The bungalow was a low, horizontal style of house with deep 
overhanging eaves and large porches, usually built of natural, textured materials. Its floor plan was notable for opening interior space. The research problem addressed in this study was to determine what factors popularized the new bungalow, a departure from its late Victorian predecessors.

The bungalow proliferated in virtually all parts of the United States between 1905 and 1920, and in order to examine causation, it was necessary to focus research on one community. McMinnville, Oregon, a small city of approximately two thous and people when the bungalow emerged, exhibits a large proportion of bungalow-style houses along its older residential streets. It was chosen as a case study within the larger overview of the bungalow as a national architectural phenomenon and served to focus the research on specific events, people, and structures.

Before treating the bungalow as it emerged in McMinnville, it was necessary to define and examine it as a general, nationwide fashion. Two chapters of this paper, then, discuss the bungalow style of architecture as a national mode of building, and the general social milieu into which it was introduced. The term itself was defined and the influences bearing upon the style's development were explored. Since architecture relates to history only because it reflects the tastes, needs, and habits of the society which produces it, the social climate of the bungalow period and the changes within middle-class American society at the time were examined. Initial research for 
these portions of the paper relied on many recent works, but much of it was done in primary sources such as magazines, newspapers, and plan books.

The fourth and fifth chapters of this paper turn to the case study, McMinnville, Oregon. McMinnville's social climate during the first two decades of the twentieth century was examined and compared with that of America's larger middle class. Research indicated that McMinnville was homogeneous and stable, characteristics not necessarily typical of the nation as a whole, but typical of that portion of society which lived in bungalows. Several bungalow-style houses, their builders, and their owners were thoroughly researched in order to provide insight into the probable causes for the bungalow's great popularity. The research conducted for this portion of the study was done almost entirely in primary source material, through interviews, and in the bungalows themselves.

The initial research problem, to discover reasons for the bungalow's rapid rise in popularity with middle-class Americans during the first two decades of the twentieth century, was not entirely resolved. The author's original thesis had been that social changes in the way middleclass Americans conducted their private lives forced them to seek and adopt a new aesthetic in the architecture of their dwellings. This appears to have been true only at an unconscious level. There were other immediate and pressing influences which popularized the bungalow: magazine and 
plan book promulgation of the style, and the resulting fashion that it became. The assertion that the bungalow answered the family's needs, however, was substantiated by the fact that the bungalow served so we11, whatever the initial reasons for its adoption. That the bungalow continues to serve in great numbers attests to the style's success. 
THE BUNGALOW AESTHETIC: THE SOCIAL IMPLICATIONS OF A NATIONWIDE PHENOMENON VIEWED FROM THE PERSPECTIVE OF A SMALL TOWN

\author{
by \\ JANICE WILLIAMS RUTHERFORD
}
A thesis submitted in partial fulfillment of the requirements for the degree of

\author{
MASTER OF ARTS \\ in \\ HISTORY
}

Portland State University

1981 
TO THE OFFICE OF GRADUATE STUDIES AND RESEARCH:

The members of the Committee approve the thesis of Janice Williams Rutherford presented May 11, 1981.

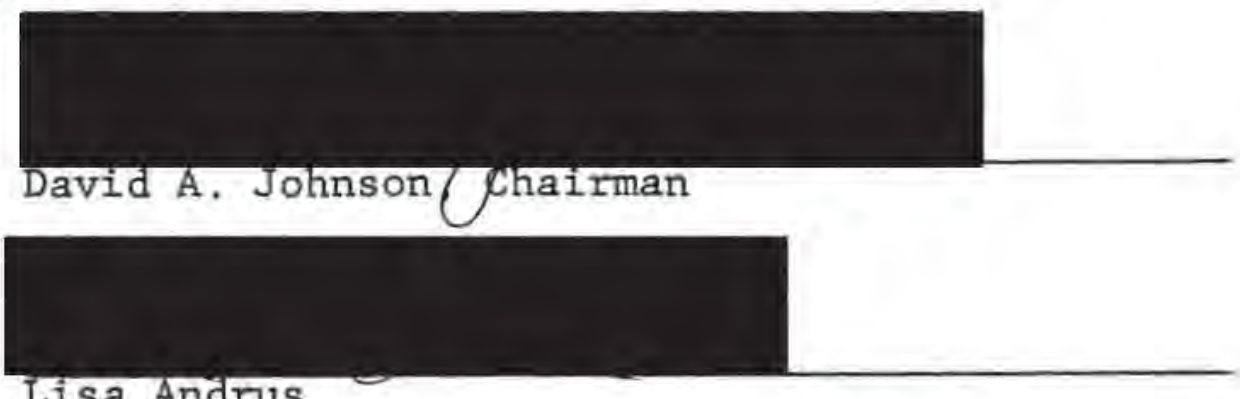

Lisa Andrus

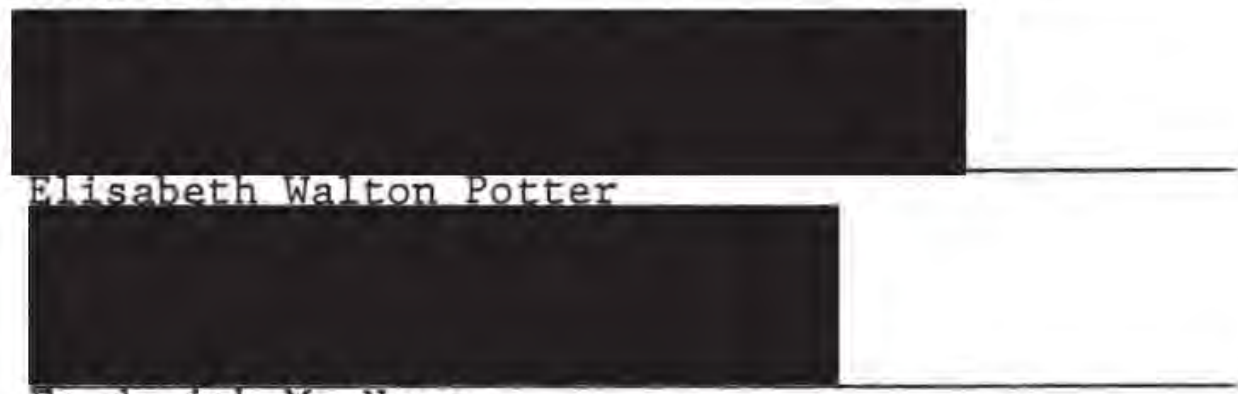

Frederick M. Nunn

APPROVED

Frederick M. Nunn, Head, Department of History

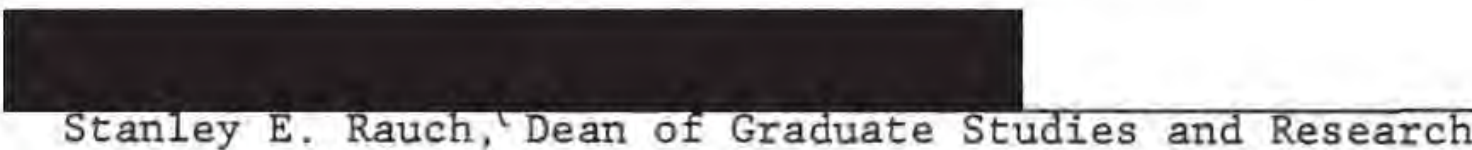




\section{ACKNOWLEDGMENTS}

Many people graciously contributed time and information as I developed this thesis and I cannot acknowledge them all here; but I do wish to thank the many citizens of McMinnville, too numerous to name, who lent assistance to this study by - opening their homes and granting interviews. I also want to express my gratitude to the staff of the McMinnville Public Library whose patience and perseverance enabled me to use a wide variety of sources in my research, and to the members of my thesis committee, David Johnson, Lisa Andrus, and Elisabeth Potter, whose generosity with time and advice was untold. I am grateful to Pamela Palm for the long, tedious hours she spent at the typewriter. And finally, for their understanding and support in the face of many trials during this project, my undying gratitude goes to my children, Melissa and Wayne. 
TABLE OF CONTENTS

PAGE

ACKNOWLEDGMENTS . . . . . . . . . . . . . . . . $i i$

LIST OF ILLUSTRATIONS ................ . . . ví

CHAPTER

I INTRODUCTION ............... I

The Bungalow in the Evolution of
American Architecture ...... 2

Methodology ............ . . 3

II DETERMINING THE PARAMETERS OF THE BUNGALOW STYLE.... 5

Definition of the Word . . . . . . . 6

Characteristics of the Style.... . 14

The Bungalow As a National Phenomenon 24

III FACTORS WHICH INFLUENCED THE DEVELOPMENT

OF THE BUNGALOW . . . . . 39

Social Conditions of the Bungalow Age $\quad 39$

Factors in the Home Which Influenced Bungalow Development..... 53

Factors Which Influenced Bungalow Design ........... . . 64

IV THE BUNGALOW AGE IN MCMINNVILLE, OREGON 81

McMinnville, 1909 - 1922: Economics, Politics, and Growth . . . . . .

The Bungalow Style in McMinnville,

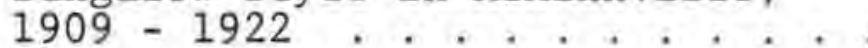


V MCMINNVILLE BUNGALOWS: TWENTY-ONE CASE STUDIES . . . . . . . . . . + . 122

The Bickford Bungalows . . . . . . . . 122

Three Commissioned Bungalows . . . . . 127

Five Substantial Bumgalows Built by Merchants......... 133

Four Elaborate Houses From the Bungalow Era .. . . . . . . . 141

Three McMinnville Houses Identified in Plan Books......... . . 156

Bungalow Design Applied to Older Houses 167

VI CONCLUSION . . . . . . . . . . . 174

SOURCES CONSULTED.,,$++++\ldots+\ldots 182$ 


\section{LIST OF ILLUSTRATIONS}

FIGURE

PAGE

1. The dak bungalow of Sigrid Gould, Allahabad, North India. . . . . . . . . . . 7

2. Three representative bungalow-style houses . . 16

3. Redrawing of a top window sash advertised in a 1908 Sears, Roebuck, and Company catalogue

4. Three examples of typical floor plans from bungalow plan books.......... . .

5. Typical bungalow interiors from the Los Angeles Company's Inexpensive Bungalows, pp. 42-43

6. A house from The Craftsman, June, 1905, p. 392

7. A traditional house from Radford's Artistic Bungalows with a traditional, closed room floor plan, p. 177 . . . . . . .

8. A bungalow with an open living room-dining room floor plan from Radford's Artistic Bungalows, p. 175 . . . . . . . . .

9. Two Greene and Greene houses which appeared in The Craftsman, April, 1909, p. 83 ....

10. A typical Craftsman house of half timber design, two-storied and stuccoed, from The Craftsman, October, 1907, p. 105 .......

11. A house from The Craftsman, March, 1909, p. 72074

12. Craftsman furniture advertisement from The Craftsman, May, 1903, p. 160 .... . . 77

13. The buildings in two representative neighborhoods in McMinnville in 1912 and 1928 . . . 84

14. The four basic types of bungalows found in McMinnville, Oregon .......... 105

15. The four basic house types in plan books . . . 106 
16. The Frank Rogers House, built by E. N. Larry,

17. Examples of houses built by similar plans in McMinnville, Oregon . . . . . . . . .

18. Photograph and floor plan of a McMinnville house built just prior to the bungalow age

19. Three examples of McMinnville, Oregon homes built during the bungalow era, but in the dormered box style........... .

20. P1an from Fenner Homes of Distinction, No. 902

21. Three McMinnville, Oregon bungalows built by James Bickford between 1912 and 1915 . .

22. Floor plans of two houses built by James Bickford, McMinnville, Oregon

23. Photograph and floor plan of house built for Frank and Carrie Wortman, McMinnville, 1909

24. Photograph and floor plan of the Dwight Miller House, McMinnville, Oregon, built between

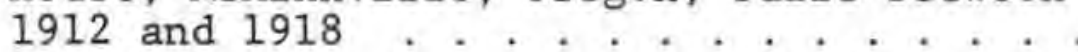

25. Photograph and plan of the Kirk P. Loop House, McMinnville, Oregon, built in 1913 . . . .

26. Photograph and plan of the Franz Dielschneider House, built in 1910, McMinnville, Oregon

27. Photograph and plan of the Alexander Cameron House, built in 1913, McMinnville, Oregon

28. The Sarah Hopfield House, the John G. Baker House, and the C. C. Jacobs House . . .

29. Floor plans of the Sarah Hopfield House and the C. C. Jacobs House. . . . . . . .

30. Photograph and blueprints of the Alva D. Hoskins House, McMinnville, Oregon.

31. The Lorenzo D. Mulkey House, McMinnville, Oregon. Frontal view and interior of dining room 
32. The Walter Link House, McMinnville, Oregon. Frontal view and interior view showing fireplace and inglenook . . . . . . . .

33. Chimneypiece in the Craftsman Restaurant, New York. From The Craftsman, January, 1914, p. 363 . . . . . . . .

34. The James H. Gibson House, McMinnville, Oregon

35. Greene and Greene drawing of the Mary Cole House from Current and Current, p. 24 .

36. James H. Cook House, McMinnville, Oregon and photograph from Craftsman Book of Bungalows, p. 67 ......... . . . .

37. The T. E. O'Neill House, McMinnville, Oregon and a photograph and plan from The Craftsman Book of Bungalows, p. 41 . . .

38. House plan from Radford's Artistic Bungalows, p. 58 .. . . . . . . . . .

39. The Delmer Wheeler House, McMinnville, Oregon

40. The E. C. Apperson House, McMinnville, Oregon when new in 1897, after alterations in 1909, and interior . . . . . . . . . .

41. The Thomas Turner House, built in 1883, and the 0 . 0. Hodson House, built before 1899

42. Chair in the James H. Gibson House 
CHAPTER I

\section{INTRODUCTION}

If there is, as Charles Matlack Price has asserted, a real and discernible connection between the evolution of humankind and the evolution of human dwellings, then domestic architecture should tell us something about the social order which creates it. 1 To discover the ways in which domestic architectural history relates to social history, we must look to the physical evidence--to the houses themselves. This study was developed to discover why, during the early years of the twentieth century, the bungalow style of architecture was introduced and within a very short time was mass-built across the entire country without regard to geography or climate. The query has been focused, due to the confines of time and place, upon a sample town, McMinnville, Oregon. In McMinnville, as in most other American towns, bungalow-style houses were built in far greater numbers than other styles, during the first two decades of the 1900's.

1C. Matlack Price, The Practical Book of Architecture (Philadelphia: Lippincott, 1976), p. 20. 
THE BUNGALOW IN THE EVOLUTION OF AMERICAN ARCHITECTURE

American architectural historians have largely ignored the evolution of style in the domestic architecture of the early twentieth century. Idaho architectural historian, Don Hibbard, writes that except for meticulous attention to the work of Frank Lloyd Wright, little note has been made of American residential architecture between 1900 and 1920 in most architectural histories. But Wright's work did not represent the mainstream of American domestic architecture; the bungalow did. Within a decade, the bungalow became the most prominent style of dwelling in the country. 2 A radical departure in style from its predecessors, the Victorian Queen Anne and the neo-colonial, the bungalow's appearance in domestic architecture indicated changes within the society which so readily embraced it. This study will examine whether these changes were evident in the lives of small town inhabitants of the new bungalows.

It may be that architectural historians have ignored the bungalow because in its popular form it was a builders' house and not the creation of architects. Architectural historians have concerned themselves with architecture as an art form and thus have treated only the major designers of

2Don J. Hibbard, "Domestic Architecture in Boise, 1904-1912: A Study in Styles," Idaho Yesterdays: The Quarterly Journal of the Idaho Historical Society, Fall, $1978, \mathrm{Pp} .2,7$. 
any given period. For this reason, until recently, the bungalow style has been overlooked, ignored, or discounted in serious historical studies. Yet to the social historian, the bungalow style emerges as a significant phenomenon simply because so many middle-class Americans were adopting it for their dwellings during the first two decades of the twentieth century. Middle America was living in a builders' house, not in an architect-designed one.

\section{METHODOLOGY}

Investigation of an architectural style and its implications must begin with the definition of that style. A great many primary sources yielded information about the bungalow style, and most attempted to define it, but perceptions varied. The few architectural historians who have treated the bungalow have offered differing views. To some, it is a house-type; to others, an architectural style. For these reasons, the definition of the term bungalow will be discussed in depth.

In order to fully understand any social implications of an architectural style, one must consider the social climate into which that style is introduced. An examination which includes historical precedent, social and artistic evolution, and cultural change during the period of the bungalow's zenith will, it is hoped, shed light upon the question posed here: why did the bungalow gain such widespread popularity? 
Having provided a picture of the larger, national environment during the bungalow period, this paper will turn to its focal question: why were most of the houses built in McMinnville, Oregon between 1909 and 1922 bungalows? A discussion of the city's social complexion at the time will be necessary to understand the people who were building bungalows . A broad overview of the city's bungalows as a group will show that the house-types chosen in McMinnville mirrored those being built elsewhere. It will also illustrate that the widespread use of mass-produced plan books influenced McMinnville's building.

In order to study more closely and specifically the influences bearing upon the choice of the bungalow style, the final chapter of this paper will focus upon twenty-one case studies of bungalows built in McMinnville. By examining the houses themselves and the people who built them, it may be possible to determine causation. 
CHAPTER II

DETERMINING THE PARAMETERS OF THE BUNGALOW STYLE

The bungalow represents a relatively recent

architectural development in America; bungalows in number appeared just seventy-five years ago, and they were still being built as late as the $1940^{\prime} \mathrm{s}$. For this reason, it is difficult to find consensus on the definition of the term bungalow. One question which arises is whether the bungalow is a type or a style.

The World Book Dictionary defines type as a "kind, class, or group alike in some important way."I Style is defined as "fashion; manner or custom that prevails."2 If every house we now call a bungalow were a "one-story lightly built house," as the word is defined in the Oxford Dictionary of Etymology, the bungalow would be a house-type. ${ }^{3}$ Research has made it clear, however, that the term bungalow, as popularly used, refers to many dwellings which do not conform to this definition but which exhibit certain elements of

${ }^{1} \mathrm{Clarence}$ Barnhart and Robert $\mathrm{K}$. Barnhart, The World Book Dictionary, 2 vols. (Chicago: Doubleday and Company, 1979), 2:2258.

2 Ibid., p. 2081.

${ }^{3}$ T. C. Onions, ed. The Oxford Dictionary of English Etymology (Oxford: The Clarendon Press, 1966, reprint ed, 1978), p. 126. 
fashion associated with the bungalow period. The word has come to denote style. In this study, therefore, the term bungalow will refer to a house which bears the characteristics of the bungalow style. This chapter will examine the word itself, the early structures to which it was applied, the characteristics of the bungalow as it evolved, and the phenomenon of the bungalow as a national style. The sources offer a wide variety of views.

\section{DEFINITION OF THE WORD}

The Oxford Dictionary of Etymology indicates that the word "bungale" was first recorded in the English language as early as the seventeenth century. According to this source, its origins are two: Gujarati, a western Indian language in which the word was spelled bangalo and Hindustani, India's major language in which the word bangla meant "belonging to Bengal." 4 Clay Lancaster cited the Bengali language as we11; the word bänglā in Bengali meant a low house with a porch all around. The English, he says, began using a corruption of this word, bungalow, to refer to the low, thatched, verandahed way stations they built along India's major routes of trave 1.5 In her 1830 diary, the wife of an East India Company employee

\section{${ }^{4}$ Ibid.}

${ }^{5} \mathrm{Cl}$ ay Lancaster, "The American Bungalow," The Art Bulletin: A Quarterly Published by the College Art Association of America, September, 1958, p. 239. 
who lived in India from 1822 until 1846 wrote:

If a house has a flat roof covered with flagstones and mortar, it is called a pukka house; if the roof be raised and it be thatched, it is called a bungalow; the latter are generally supposed to be cooler than the pukka houses. The rooms of our house are lofty and good...

She wrote that their house was a bungalow "for it is tiled over a thatch."6 Figure 1 shows the Indian home of Sigrid Gould who lived in North India from 1932 until 1947. It was called a dak bungalow, or government bungalow. ${ }^{7}$ The

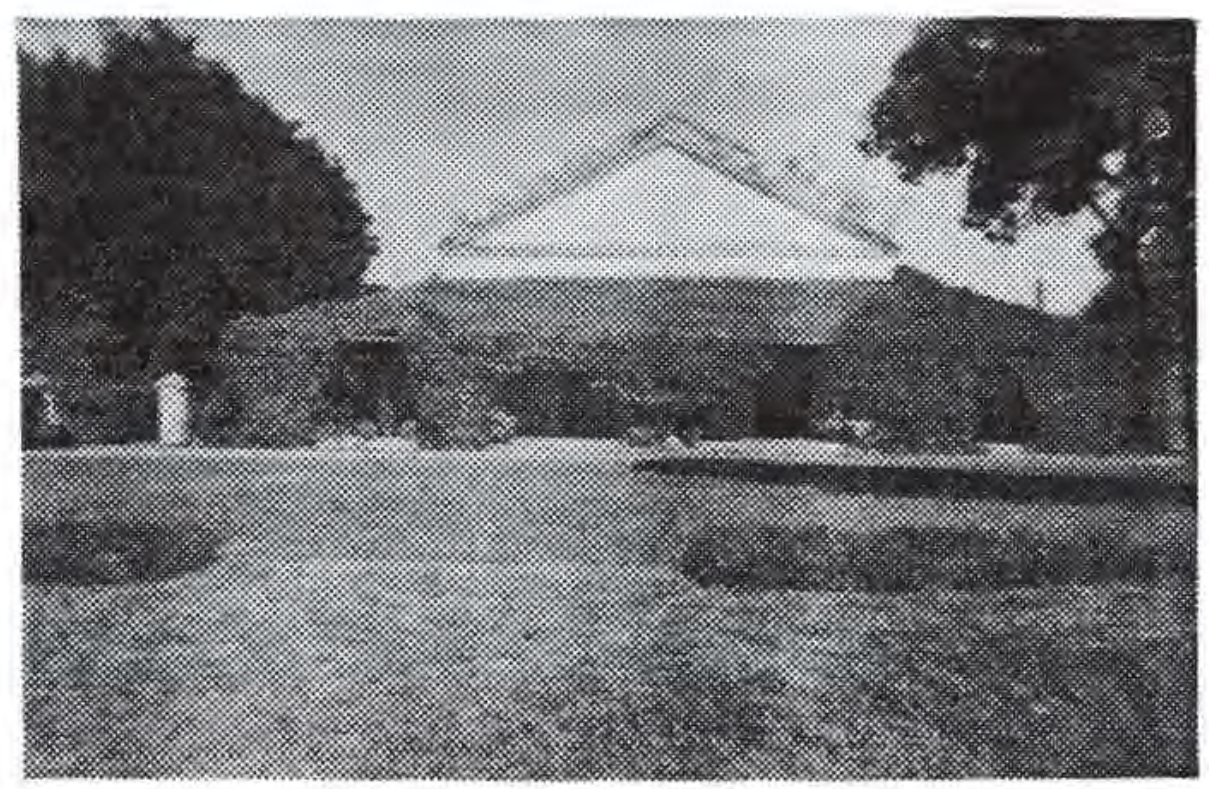

Figure 1. The dak bungalow of Sigrid Gould, Allahabad, North India.

${ }^{6}$ Fanny Parks, Wanderings of a Pilgrim in Search of the Picturesque, 2 vols. (London: Pelham Richardson, 23, Cornhill, 1850, reprint ed., Karachi: Oxford University Press, 1975), 1:135-137.

${ }^{7}$ Sigrid Gould, interview, McMinnville, Oregon, March 20, 1981. 
word bungalow appeared in England with reference to structures built there in 1891 in a book by R. A. Briggs entitled Bungalows and Country Houses. ${ }^{8}$ It was used in America even earlier when an 1896 article in American Architect and Building News described a clapboard-sided stick-style house with a verandah as a bungalow. ${ }^{9}$

Both the Oxford Dictionary of Etymology and Henry Saylor's architectural dictionary define bungalow rather narrowly as a one-story house, but Webster's New International Dictionary of the English Language expands the meaning with its second definition:

By extension, a more or less solidly constructed home for permanent residence, generally of one story, but sometimes of a story and a half preserving only the low sweeping exterior lines and wide verandah (generally on the front only) of the bungalow of India.10

Marcus Whiffen objects to the term bungalow in reference to a two-story house, but he concedes that many two-story houses exhibit bungalow-like features. His

$8 \mathrm{James}$ D. Kornwolf, M. H. Baillie Scott and the Arts and Crafts Movement (Baltimore and London: The Johns Hopkins Press, 1972), P. 48.

${ }^{9}$ Lancaster, The Art Bulletin, p. 239.

100nions, p. 126; Henry W. Saylor, Dictionary of Architecture (New York: John Wiley and sons, Inc., 1952), P. 27; William Allan Neilson, ed., Webster's New International Dictionary of the English Language, 2nd ed.

(Springfield, Mass.: G. \& C. Merriam Company, Publishers, 1959), p. 356. 
solution is to use the adjective, bungaloid.11 Architectural historian, John Blumenson, also defines the bungalow as a one-story house, but his illustrations of the style include a one and one-half story example. 12

Sources contemporary with the bungalow varied in their definitions of the term as well. A detailed definition of the word bungalow appeared in the McMinnville, Oregon Telephone Register in 1911. Quoting from Country Life in America, the article described the Indian bungalows, designed and built by Englishmen, as low shelters constructed of two walls of canvas with thatched roofs and interior canvas partitions.13 A 1906 issue of The Craftsman magazine labeled a rather tall, two-story wooden dwelling of box construction a bungalow. A later issue attempted to define the bungalow as a small house of perhaps six rooms which conformed to its landscape and which exhibited Japanese or Swiss influence;

11Marcus Whiffen, American Architecture Since 1780: A Guide to the Styles (Cambridge, Mass.: The M.I.T. Press, 1969), pp. 217-219. The word bungaloid, according to Webster's International Dictionary, p. 356, means "of or resembling a bungalow.

$12 \mathrm{John} \mathrm{J}$. - G. Blumenson, Identifying American Architecture: A Pictorial Guide to Styles and Terms 16001945 (Nashville: American Association for State and Local History, 1977), p. 71

${ }^{13}$ The McMinnville (Oregon) Telephone Register, April 7 , 1911, p. 10. 
and a still later one called a two-story stucco house with a rather high-pitched jerkinhead roof a bungalow. 14

The self-styled "bungalow Man," Henry L. Wilson, whose book on bungalows went through five editions from 1907 to 1910, described the bungalow as a low, rambling house, quaint, attractive, and above all, cozy. 15 Henry Saylor, a widely published architectural authority, defined the bungalow quite strictly as a one-story adaptation of the Indian prototype although he admitted that in the interests of convenience, modern bungalows might have bedrooms in the attic space. Saylor thought the bungalow best suited to seasonal, temporary dwelling and wrote that the suburban variety was probably nothing more than a passing fad. He attempted to classify bungalows within this narrow definition and listed variations: 1) the California bungalow, 2) the patio bungalow, 3) the Swiss Chalet, 4) the temporary shack, 5) the summer retreat, 6) the large, multi-massed lodge, 7) the seacoast bungalow, 8) the Midwest bungalow, 9) other regional types, and 10 ) a house which was not a bungalow but built

${ }^{14}$ The Craftsman, December, 1906, pp. 393-398; January, 1908, pp. 450-457; June, 1913, p. 327.

${ }^{15}$ National Union Catalog: Pre-1956 Imprints, 705 vols. (London: Mansel1 Information/Publishing, Ltd, 1968), 666: 627-628; Henry L. Wilson, The Bungalow Book: A Short Sketch of the Evolution of the Bungalow From its Primitive Crudeness to its Present State of Artistic Beauty and Cozy Convenience (Chicago: Henry L. Wilson, 1910), p. 3. 
upon bungalow lines. 16 Several of Saylor's illustrations showed houses with no eaves although deep eaves were a hallmark of the bungalow. He insisted that under no circumstances did the true bungalow exhibit a roofline punctured by dormers, but builders' bungalows nearly always had dormers. His Midwest bungalow, category number eight, was actually a prairie house and the tenth category, houses which were "built upon bungalow lines," represented virtual admission that the narrower definition excluded too many structures which bore bungalow features. 17 This group included twostory houses which were, in every aspect except height, bungalows. Saylor's difficulty in describing a bungalow in precise terms resulted in a final attempt which left room for considerable diversity:

The final test is in the plan. Where the main sleeping rooms are included on the first floor with the living room and service quarters, the building is a bungalow. Where the sleeping quarters are for the most part on the second floor, the building is a house instead.18

One 1912 plan book noted that the bungalow style influence was found in one and one-half and two-story forms. 19

${ }^{16}$ Henry H. Saylor, Bungalows: Their Design, Construction and Furnishings, with Suggestions Also for Camps, Summer Homes and Cottages of Similar Character, 4 th ed. (New York: Robert M. McBride and Company, 1926), PP, 5-6, 19-45.

17 Ibid., pp. 40-41.

18 Ibid., p. 45.

${ }^{19}$ Los Angeles Investment Company, Inexpensive Bungalows, 9th ed. (Los Angeles: George Rice and Sons, 1912), p. 3. 
Another lamented the fact that some architects applied the term bungalow to "crude alterations to cottages," but advertised mission style stucco homes and flat-roofed cement structures as bungalows. 20 C. Matlack Price, writing in 1916, had similar difficulty defining the term bungalow. After quoting Webster's first definition, he added that the American bungalow was quite different than the Anglo-East Indian structure from which it took its name, that nearly all American bungalows were one and one-half stories high. Price agreed with other writers that the term was often used incorrectly. 21

A report published by the United States Housing Corporation added further confusion. Outlining the procedure followed in building temporary emergency housing for the war effort, the Corporation pictured several designs for threeto six-room dwellings which they called bungalows. These houses had no eaves, no large porches, and no exposed structural members. Instead, they were small compact wooden houses more akin to what was later called the Cape Cod style than to the bungalow. 22

20 Jud Yoho, Craftsman Bungalows: Edition Deluxe: A Collection of the Latest Designs (Seattle: Jud Yoho, 1914), pp. 2, 7, 8, 14 .

$21_{\text {Price, p. } 201 .}$

22United States Housing Corporation, Report of the United States Housing Corporation, 2 vols. (Washington, D. C. : Government Printing Office, 1919), 1:204. 
By 1915, The Craftsman magazine was featuring different styles of bungalows. One picture of a "colonial bungalow" (the editor's quotation marks may have apologized for this contradiction in terms) shows a square, hip-roofed, one-story house with vaguely classical consoles under a small portico as the only hint of colonial architecture. 23 The Woman's Home Companion publication, The Little Book of Bungalows and Cottages showed several houses with colonial or Tudor elements in 1921. None resembled the low, deep-eaved bungalow of earlier publications and the compiler wrote that the bungalow could be adapted to many styles. 24

The word bungalow gradually became a part of America's common dialect. In 1909, two enterprises advertising in a business directory in Portland, Oregon used the word in their names: The Bungalow Saloon and the Bungalow Home Baking Company. 25 By 1930 , eleven of the businesses listed used the term; there were bungalow apartments, bungalow groceries, even bungalow shoe stores. 26 The word had become fashionable.

${ }^{23}$ The Craftsman, July, 1915, p. 411.

${ }^{24}$ Charles Vaughn Boyd, comp., The Little Book of Bungalows and Cottages (New York: The Woman's Home Companion,

25 Portland City Directory (Portland, Oregon: R. L. Polk and Company, 1909), p. 351.

26Portland City Directory, 1930, p. 323. 
CHARACTERISTICS OF THE STYLE

Exterior characteristics common to most bungalows were: horizontality in feeling if not in fact, the use of natural, textured materals, exposed structural members, and large porches. The exterior configuration very often expressed the interior plan; it was made to harmonize with the desired arrangement of rooms, according to a 1908 plan book. 27 Karen Current writes that the California bungalows were small and modest with long, low rooflines built of natural materials and designed for indoor-outdoor living. 28 Saylor mentioned the desirability of bringing the roofline of the bungalow down to tie the structure more firmly to its site and the author of Radford's Artistic Bungalows wrote that the bungalow was the "result of the effort to bring about harmony between the house and its surroundings," 29 In defense of occasional verticality in the bungalow (which one sees rather often in early bungalow plan books), Saylor mentioned that it might be appropriate to include vertical elements in a forest bungalow

27The Bungalow Plan Company, The Bungalow Plan Book (Los Angeles: The Bungalow Plan Company, 1908), p. 2.

28Karen Current and William Current, Greene and Greene: Architects in the Residential Style (Fort Worth: Amon Carter Mus eum of Western Art, 1974), p. 11.

${ }^{29}$ Saylor, Bungalows, pp. 56-57; The Radford Architectural Company, Radford's Artistic Bungalows (Chicago: The Radford Architectural Company, 1908), p. 3. 
in order to affirm the verticality of the trees. 30 Several typical bungalows appear in Figure 2 .

Prominent porches, large, textured chimneys, pergolas and sleeping porches were elements which became associated with the bungalow style, and although not all bungalows included all of these features, they appeared often enough to become hallmarks. The porch, Edith Allen suggested, was a particularly American feature of the dwelling house. She wrote that it evolved from the Dutch penchant for extending roofs in broad, sheltering eaves. 31 Henry-Russell Hitchcock maintained that the American porch, a nineteenth-century result of the Picturesque Movement in architecture, was influenced by several historical precedents: the Indian verandah, the Italian loggia, the Tudor arcade, the Swiss gallery, and the classical portico. 32 Whatever its genesis, the porch was an important part of bungalow architecture. Saylor suggested that it should be treated as another room and furnished with floor covering, potted plants, and wicker furniture, thus making it a means of communicating with the

30 Saylor, Bungalows, p. 55.

31Edith Louise Allen, American Housing As Affected By Social and Economic Conditions (Peoria, Illinois: The Manual Arts Press, 1930), p, 34.

32Henry-Russell Hitchcock, Architecture: Nineteenth and Twentieth Centuries, 2nd ed. (Baltimore: Pelican Books, 1958), P. 254. 


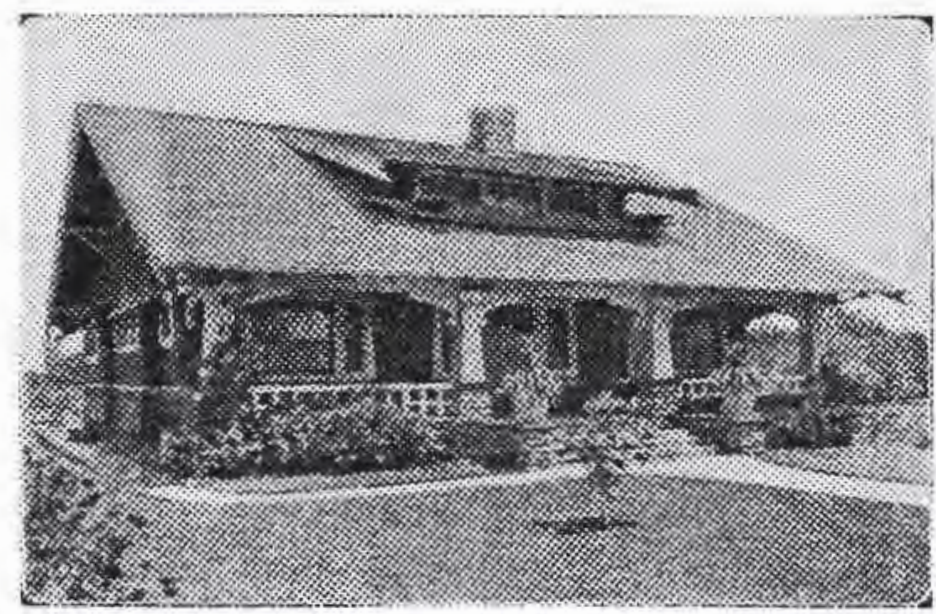

From the Ladies' Home Journal, January, 1909, p. 35.

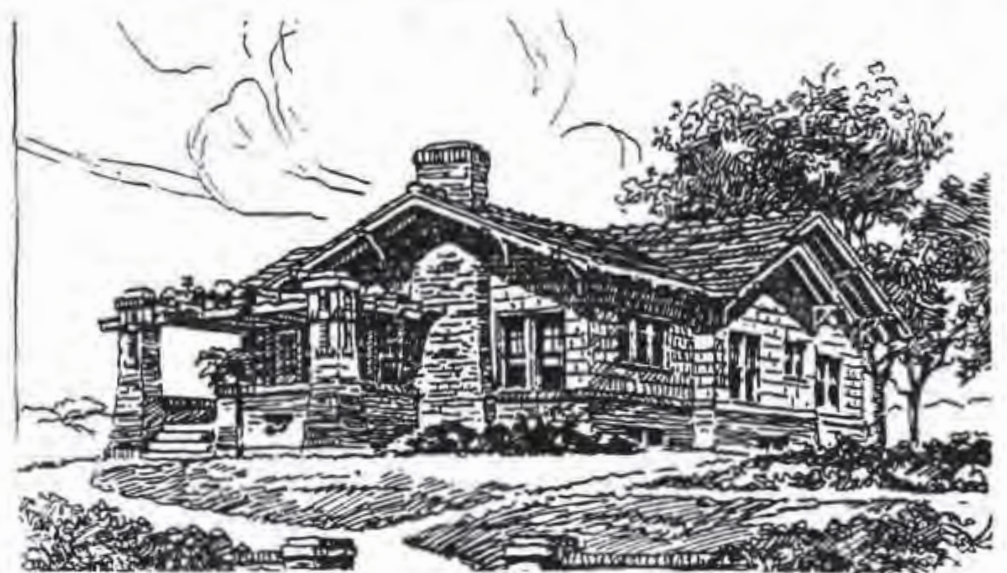

From Lindstrom and Almars, Bungalows (Minneapolis: Lindstrom and Almars, n. d.) No. 168.

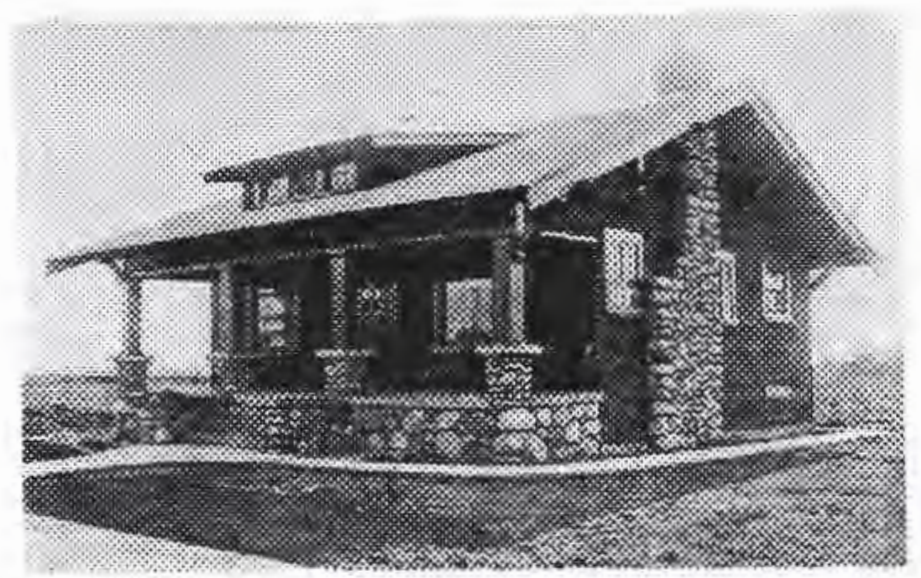

From Inexpensive Bungalows, p. 42.

Figure 2. Three representative bungalow style houses. 
out-of-doors. He also proposed using the pergola as an alternative to the porch, thereby eliminating the problem of darkened windows beneath. 33

The chimney was often a focal point in bungalow architecture. Saylor thought that a fireplace was a necessity and he suggested that it be made of stone to harmonize with the roughness of natural woods. 34 The Craftsman magazine also preferred decorative chimneys built of cobblestone, clinker brick, or river rock. ${ }^{35}$ A stone or brick chimney was often a prominent exterior feature in even the simplest of bungalows. (See the last example in Figure 2.)

The windows of bungalows varied considerably but a common type was the multi-lighted, smaller, upper sash over a larger, single-lighted, lower one. The lights of the upper sash might be simple squares or rectangles or they might be decorative shapes of fine beveled, leaded glass, By 1908, Sears, Roebuck, and Company was selling a typical style, the upper sash of which was of diamond and elongated hexagon shapes. 36

${ }^{33}$ Saylor, Bungalows, pp. 156-157, 80.

${ }^{34}$ Ibid., pp. 135-147.

${ }^{35}$ The Craftsman, August, 1908, p. 539.

36 Joseph J. Schroeder, ed., Sears, Roebuck and Company 1908 Catalogue Number 117 (Chicago: Follett Publishing Co., reprint ed., Chicago: The Gun Digest Co., 1969), p. 596 , 


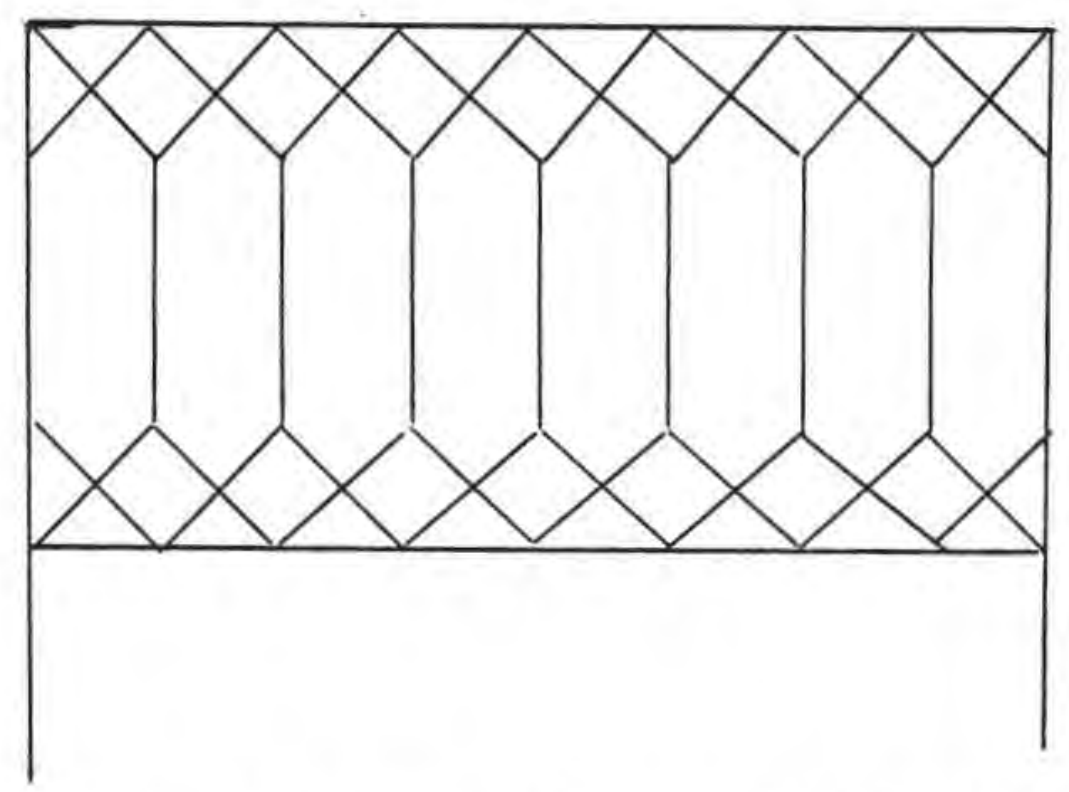

Figure 3 . Redrawing of a top window sash advertised in a 1908 Sears, Roebuck and Company catalogue.

With the emergence of new ideas in the promotion of health, ventilation became an important aspect of the wellbuilt home. 37 This new interest in fresh air coincided with the rise of the bungalow, and an important feature of many bungalow designs was the sleeping porch, an unheated room, usually at the rear of the house, ventilated by a row of windows or screens. 38 Saylor praised the sleeping porch and several articles in the Ladies' Home Journal between 1907 and 1915 offered ideas for converting the porches of older

37 See F. H. King, Ventilation for Dwellings, Rural Schools, and Stables (Madison, Wisconsin: F. H. King, 1908).

${ }^{38} \mathrm{Cl}$ ay Lancaster, The Japanese Influence in America (New York: Walton H. Rawls, printed in Japan by Book Craft, Inc., 1963), p. 128. 
homes into sleeping porches or for building sleeping porch additions. 39

The bungalow's departures from more traditional styles of architecture were not confined to its exterior. Even greater changes occurred inside the American house during the bungalow years and it is perhaps in this regard more than in any other that the bungalow was a true innovation. Basic to bungalow design was free use of space. As Karen Current points out, the bungalow did away with the parlor and introduced the living room. 40 Bungalows usually combined the living spaces which had formerly been separated into sitting room, dining room, and entry and created one continuous living area. Plan books of the period consistently showed a living-dining space with only an arch defining the separation; often there was no articulated entryway at all. Bedrooms were usually separated from living space by a hall, but in later, less expensive bungalows, the hall was sometimes eliminated. (See Figure 4.)

${ }^{39}$ Saylor, Bungalows, p. 81 ; Ladies' Home Journal, April, 1907, p. 39; September, 1908 , p. 27; October, 1908, p. 35; September 1, 1910, p. 37; April, 1913, p. 105; June, 1915 , p. 24; September, 1915, p. 27. One article suggested putting a bed through an open window onto which a tent-like awning had been attached or placing one end of a flexible tube out an open window and the other over the sleeper's head.

${ }^{40}$ Current and Current, p. 11. 


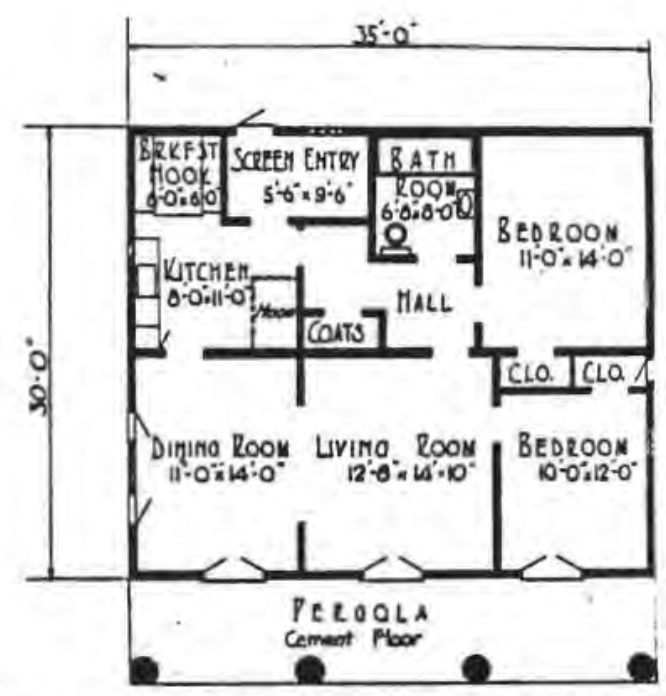

From Fenner Homes of Distinction (Portland, Oregon:

Fenner Manufacturing Company, 1924), No. 902.

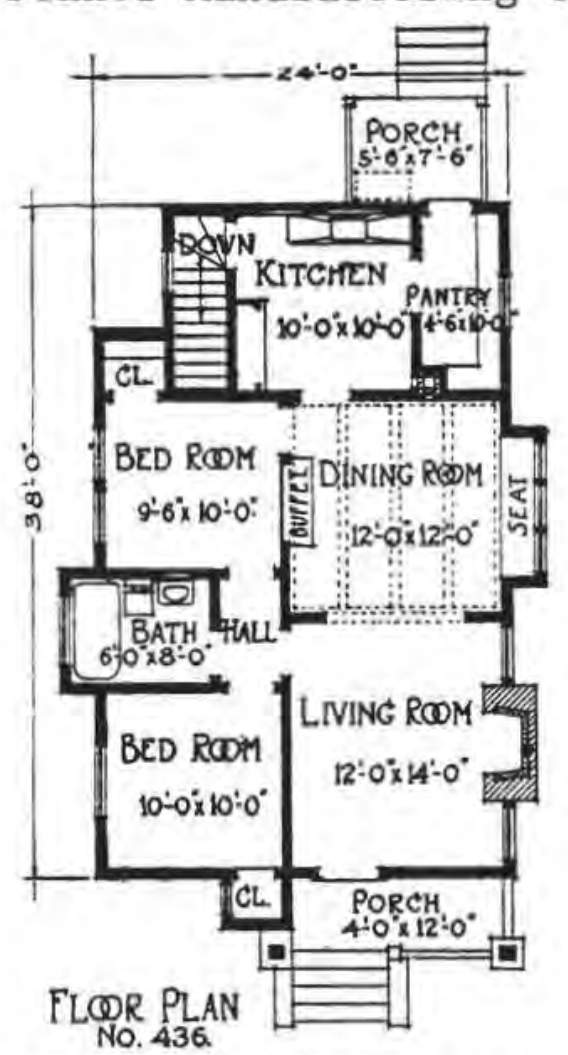

From Yoho, Craftsman Bungalows, p. 83 .

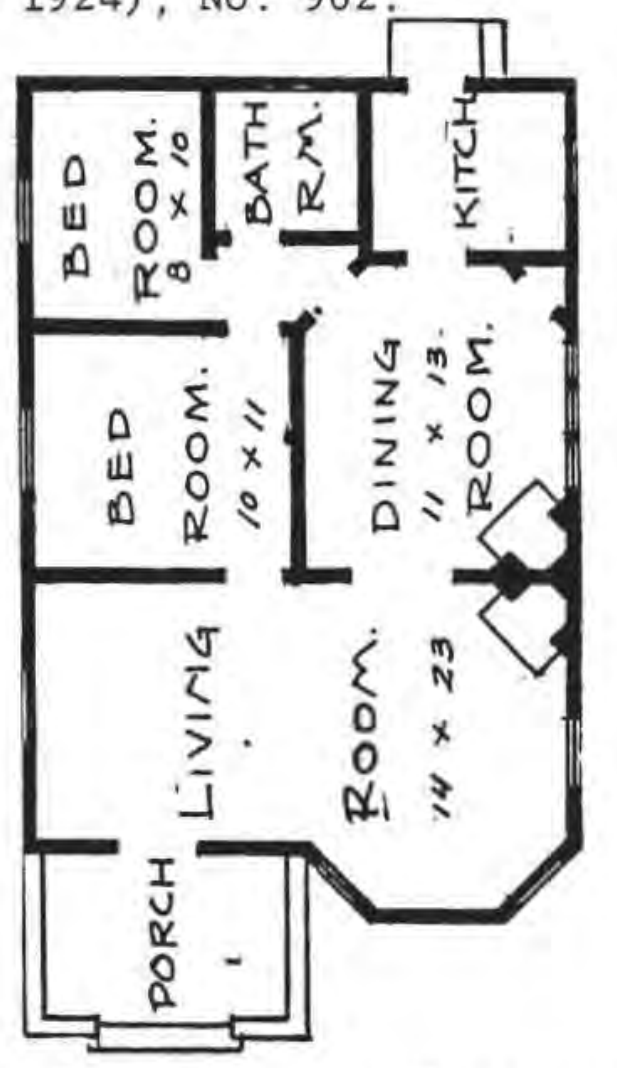

From Bungalows and Cottages (Minneapolis: Max L. Keith, 1908), No. K1317.

Figure 4. Three examples of typical floor plans from bungalow plan books. 
The interior finish of the bungalow was usually consistent with the preference for natural materials. Taste for informality and fine craftsmanship led to extensive use of natural woodwork. Even later, mass-produced bungalows exhibited naturally finished wood and a great deal of builtin cabinetwork. Heavy wooden square posts in arches, builtin bookcases, china closets with leaded-glass doors, window seats, and inglenooks were popular. One author preferred the built-ins as an alternative to what he called a "garish display of . . . bizarre furniture."41 The use of natural materials extended to the fireplace where either the same river rock or cobblestone of the chimney or ceramic tiles of natural colors were used. Exposed beams in at least one room (usually the dining room) were often used to express structure inside the house. (See Figure 5.)

Advances in technology made the bungalow one of America's first convenient houses. Residential plumbing was widespread by the early 1900's. 42 Virtually all bungalow designs showed a bathroom and a kitchen with plumbing. The kitchen became smaller, more compact, and more efficient. In

41 Los Angeles Investment Company, Practical Bungalows of Southern California, 9th ed., (Los Angeles: George Rice and Sons, n. d.), p. 3 .

42 See R. M. Starbuck, Questions and Answers on the Practice and Theory of Sanitary Plumbing, 6th ed. (Hartford: Smith-Linsey Company Printers, 1904). 

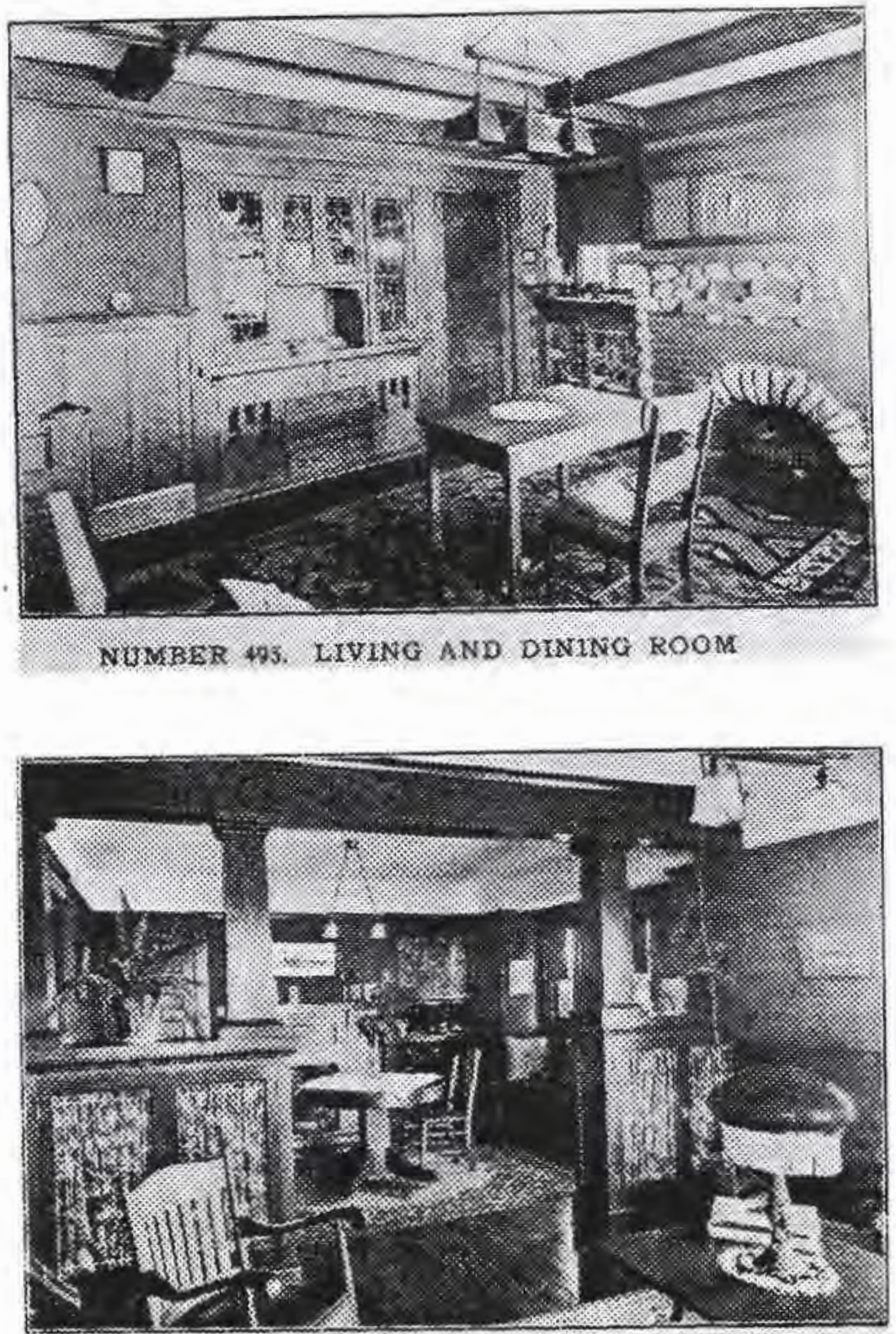

NO. 372 B. LIVING AND DINING ROOMS

Figure 5. Typical bungalow interiors from The Los Angeles Company's Inexpensive Bungalows, pp. 42-43. 
the words of M. H. Lazear, the ideal had become a convenient kitchen with "snug placement of work areas."43 A plan book of the day claimed that the modern kitchen was provided with "many utilities unknown to the housewife of earlier days." 44 Jud Yoho of Seattle suggested for his bungalows what he called a buffet kitchen as an alternative to the oldfashioned pass pantry. ${ }^{45}$ A 1915 issue of the Ladies' Home Journal features several kitchens with entire walls of floorto-ceiling built-in cabinets and drawers, 46 Boyd wrote in 1921 that the desirable modern kitchen should be small and washable with built-in cabinets and closets, a decided contrast to the large Victorian kitchen with free-standing cupboards and tables. 47 By 1913, The Craftsman was showing a very modern tiled bathroom with built-in drawers. 48

${ }^{43}$ M. H. Lazear, "The Evolution of the Bungalow," The House Beautiful, June, 1914, P. 2. p. 3 .

${ }^{44}$ Los Angeles Investment Company, Inexpensive Bungalows,

45 Yoho, pp. 56-57.

${ }^{46}$ Ladies' Home Journal, January, 1915, p. 28.

47 Boyd, p. 4.

${ }^{48}$ The Craftsman, April, 1913, p. 109. 
THE BUNGALOW AS A NATIONAL PHENOMENON

The following poem, published in Good Housekeeping Magazine and reprinted by Henry Saylor in 1910, suggests that the American fondness for the bungalow approached a mania.

\author{
Bungal-Ode \\ by Burgess Johnson
}

There's a jingle in the jungle,

'Neath the juniper and pine,

They are mangling the tangle

of the underbrush and vine,

And my blood is all a-tingle

At the sound of blow on blow,

As I count each single shingle

On my bosky bungalow.

There's a jingle in the jungle,

I am counting every nail,

And my mind is bungaloaded, Bungaloping down a trail;

And I dream of every ingle Where I angle at my ease,

Naught to set my nerves a-jingle, I may bungle all I please.

For I oft get bungalonely In the mingled human drove, And I long for bungaloafing In some bungalotus grove, In a cooling bung' location Where no troubling trails intrude,

'Neath some bungalowly rooftree In east bungalongitude.

Oh, I think with bungaloathing of the strangling social swim, Where they wrangle after bangles

Or for some new-fangled whim;

And I know by bungalogic

That is all my bungalown

That a little bumgalotion Mendeth every mortal moan: 
Oh, a man that's bungalonging For the dingle and the loan

Is a very bungalobster If he dangles on at home. Catch the bungalocomotive; If you cannot face the fee, Why, a bungaloan' 11 do it-- 49

That the bungalow became a national house style is beyond question. Most authors agree that its American beginnings were in California, whether due to climate, life style, or particular western designers. The style spread rapidly and some of the earliest plan books, dating from 1906 and 1908, were written and published in the Midwest. 50 Buffalo, New York built bungalows in numbers great enough to warrant a recent study by the State University of New York, 51

Clay Lancaster has written that the California version of the bungalow probably did not derive inspiration directly from the Indian prototype but rather developed similar characteristics because of similar conditions: climate and the desire for simplicity. He suggests that its rapid development was due to California's sudden population growth from the influx of retirees and fortune seekers. 52

${ }^{49}$ Saylor, Bungalows, p. 2.

50Two examples are: Radford's Artistic Bungalows and Fred T. Hodgson, Practical Bungalows and Cottages for Town and Country (Chicago: Frederick J. Drake and Company, 1906).

51 Frances Downing, Assistant Professor, Department of Architecture, State University of New York at Buffalo, interview at Portland, Oregon, January 5, 1981.

52Lancaster, The Japanese Influence in America, p. 104. 
Karen Current points to the state's abundant resources, the immigration of European craftsmen and Japanese gardeners, and the demand for moderately priced housing. She views the bungalow as a California vernacular style. 53

Early writers also ascribed the bungalow's development to Californians. A 1908 Craftsman magazine article divided Pacific Coast architecture into three types: mission, Spanish colonial, and Craftsman-influenced. (As we will discuss later, The Craftsman was influential in the promulgation of the bungalow.) According to this article, the bungalow was a subtype which fell within the Craftsmaninfluenced category. Its characteristics were: sloping roofs, verandahs, rough timbers, overhanging eaves, exposed construction, and pergolas. 54 Fred Hodgson and Henry Wilson both traced inspiration for the bungalow to the low, onestory adobes which dated from a much earlier California. 55 Lazear, writing for House Beautiful in 1914, attributed the bungalow's development in California to the fact that early settlers often lived in barns before building permanent dwellings and in doing so, discovered the convenience of indoor-outdoor passage and larger, open living spaces. 56 Lazear may have gotten this theory from a 1909 Craftsman

${ }^{53}$ Current and Current, pp. 4-5, 10. 54 The Craftsman, January, 1908, pp. 450-457. 55Hodgson, Practical Bungalows, pp. 6-7; Wilson, p. 3. 56Lazear, p. 2. 
article which reported that a great many Santa Barbara houses had evolved from barns. 57 Lazear's barn theory may not withstand close examination, but he noted one important factor which contributed to the bungalow's development. Because of the mild climate, Lazear thought that California builders more readily embraced the balloon construction methods developed in the nineteenth century. This method of applying siding material to evenly spaced, single, continuous, upright studs was far cheaper and faster than the traditional heavy timber framing and made the bungalow economically attractive. 58

Even though the bungalow developed first in California, it spread rapidly to other parts of the nation. As noted earlier, Clay Lancaster found reference to a Massachusetts bungalow as early as 1896.59 In another work, he reproduced a 1902 drawing entitled "An East Indian Bungalow" which had appeared in the Brooklyn Daily Eagle. 60 The bungalow traveled rapidly up the coast to the Pacific Northwest and with a few adaptations, became as popular in Washington, Oregon, and Idaho as it was in California. Jud Yoho, one of several Seattle bungalow salesmen, wrote in 1914 that since the California bungalow made no provisions for

57 The Craftsman, January, 1909, pp. 598-603.

58Lazear, p. 2.

${ }^{59}$ Lancaster, Art Bulletin, p. 240.

60Iancaster, The Japanese Influence in America, pp. 126-128. 
basements or heating apparatus, Northwesterners needed plans especially designed for cooler climates. 61 Don Hibbard traces the introduction of the bungalow in Boise, Idaho to a California architect names J. Flood Walker as early as 1904.62

Two of the most effective means of promulgating bungalow architecture were popular magazines and plan books. In the early 1900's, ladies' monthly magazines were becoming a decided influence, and among the several that were popular, the Ladies' Home Journal was one of the most widely read. It began publication in 1883 and by its twenty-fifth anniversary in 1909, circulation had reached 1,325,000.63 Another magazine which promoted the bungalow style was Gustav Stickley's The Craftsman, an erudite publication based on the philosophy of William Morris and the Arts and Crafts Movement. The Craftsman appealed to a far smaller audience than the Ladies' Home Journal, but its influence is obvious in many of the plan books which were sold during its years of publication. Plan books were printed in great numbers all over the country, from Los Angeles to Seattle, from Cedar Rapids to Chicago, from Minneapolis to New York.

Following the bungalow through the pages of the Ladies' Home Journal from 1906 to 1915 gives one a sense of the

$61_{\text {Yoho, p. } 2 .}$

62 Hibbard, pp. 3-4.

${ }^{6}$ Ladies' Home Journal, April, 1909, p. 1. 
style's rapid rise to a nationwide fashion. In each of four early issues of 1906, the Journal's regular two-page feature of homes shows only one structure resembling the bungalow style. 64 In October's issue, the house plan of the month is a one and one-half story gable-roofed bungalow priced at $\$ 2,000.65$ The first notable display of bungalows along with the use of the term itself appeared in November, 1906. The feature was entitled "Some Inexpensive Bungalows" and presented photographs of several Pasadena, California homes. 66 The bungalow became a recurring theme in 1907; both the July and November issues carried two-page home features which pictured only bungalows. 67 The magazine carried a series of articles stressing the economy of the bungalow style in 1908 . "The One-Thousand Dollar Bungalow" appeared in March, "The Two-Thous and Dollar Bungalow" in April, and "The ThreeThous and Dollar Bungalow" in May. The houses pictured ranged. from the very simple to the moderately elaborate. Porches and river rock were common features.68 During 1909 and 1910 the bungalow appeared more often and in more profusion in

64Ladies' Home Journal, February, 1906, pp. 34-35; March, 1906, pp. 40-41; Apri1, 1906, p. 35; August, 1906, Pp. 24-25.

65Ladies' Home Journal, October, 1906, p. 33.

66 Ladies' Home Journal, November, 1906, p. 33.

67'Ladies' Home Journal, July, 1907, p. 21; November, 1907, pp. 50-51.

68 Ladies' Home Journal, March, 1908, p. 29; April, 1908 , p. 23; May, 1908, p. 33. 
articles with titles like: "If You Intend to Build a Bungalow," "The Bungalow Made of Plaster," and "When You Intend to Build a Bungalow." A 1910 article explained that "the bungalow is becoming more and more popular each year, mainly because its easy housekeeping possibilities make such a strong appeal to women."69 In 1913, an unusual bungalow court was featured: a compound of twenty-four bungalows designed to house thirty families. 70 The bungalow had entered the mass housing market. An article on investment bungalows appeared in 1915.71

The Craftsman, too, promulgated the bungalow style from 1901 until it ceased publication in 1916. Stickley offered house designs as a regular feature and for the price of subscription, readers were entitled to mail-order plans free of charge. 72 Not all Craftsman homes were bungalows, but by 1905 some of its plans began to exhibit elements of the style: sloping roofs extending over front porches, large square porch posts, dormers, and prominent chimneys. (See Figure 6.) Frequent features picturing bungalows began appearing by 1908; many showed designs other than The

${ }^{69}$ Ladies' Home Journal, January, 1909, pp. 34-35; March, 1909, p. 29; July, 1910, pp. 30-31, 33-34.

70Ladies' Home Journal, April, 1913, p. 99.

71 Ladies' Home Journal, January, 1915, p. 36.

72 The Craftsman, December, 1906, p. xii. 
Craftsman's own and featured bungalows from Southern California, thus advertising them nationally. 73

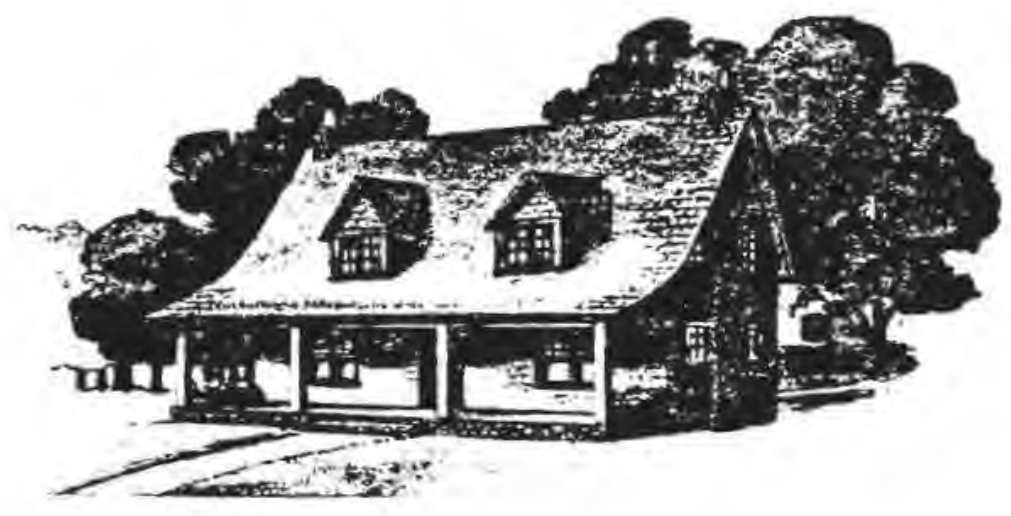

Figure 6. From the Craftsman, June, 1905, p. 392.

Other magazines helped popularize the bungalow too.

In 1908, Good Housekeeping, another popular woman's journal, ran a series of articles on model towns, one of which featured Pasadena, California bungalows. In another issue the same year, Good Housekeeping printed an article entitled, "Planning the Bungalow."74 The magazine campaign to make the bungalow a nationwide fashion was unquestionably successful.

73The Craftsman, March, 1905, pp. 736, 742; September, 1908, pp. 650-662; May, 1909, pp. 216-221.

74Good Housekeeping, January, 1908, pp. 12-20; February, 1908, pp. 140-144. 
A 1914 issue of House Beautiful pictured a typical bungalow on Long Island and carried an article entitled, "Two Connecticut Bungalows."75

The great number of bungalow plan books published during the first two decades of the twentieth century attests to the bungalow's general popularity. Blueprints costing from $\$ 5.00$ to $\$ 15.00$ were offered in catalogues printed across the country from Los Angeles to New York. Magazines helped to promote the plan books; advertisements for catalogues appeared in the Ladies' Home Journal, Good Housekeeping, and even in The Craftsman.

Los Angeles was the home of several plan book companies. Henry Wilson published the first four editions of The Bungalow Book in Los Angeles and several other firms including the Bungalowcraft Company and the Los Angeles Investment Company were located there. Their catalogues were published from 1910 until 1931.76

Many plan books were published in the Midwest. Fred Hodgson, a prolific writer on the subjects of building and architecture, published nine bungalow catalogues in Chicago from 1904 to 1916. Other Chicago publications were U. M. Dustman's Construction of Dwelling Houses and

75 76The National Union Catalog: Pre-1956 Imprints, 84 : $200-201$; 666:627-628; 342:28; Los Angeles Investment Company, Inexpensive Bungalows. 
Bungalows, printed in several editions from.1910 to 1916 , and Radford's Artistic Bungalows, 1900 to 1913.77 The Keith Company from Minneapolis published catalogues from 1908 to 1925 and at least two Iowa firms, Gordon-Van Tine and Brown Brothers advertised plans in popular magazines. 78 Daverman's Book of Bungalows was published by a Grand Rapids, Michigan firm from 1906 until at least 1911 and another Michigan firm, North American Construction Company developed the ready-cut houses which later became Aladdin Homes. ${ }^{79}$ From the East Coast, P. J. McLagan of Newark, New Jersey and E. E. Holman of Philadelphia offered bungalow plans by mail. 80

Several home designers in the Pacific Northwest published plan books; John Hunsicker printed a catalogue in Eugene, Oregon; H. M. Fancher offered mail-order plans from Portland, and in Seattle, the firms of Jud Yoho and V. W. Voorhees sold bungalow plans, 81 Two Portland firms as well

77 National Union Catalog: Pre-1956 Imprints, 249 : $216-224 ; 153: 162 ; 478: 611-618$.

78National Union Catalog: Pre-1956 Imprints, 292: 29-30, 40; Ladies Home Journal, April, 1909, p. 93; October, 1915 , p. 90 .

${ }^{79}$ National Union Catalog: Pre-1956 Imprints, 134:129; Ladies' Home Journal, March, 1907, p. 50; February 15, 1911, p. 32 . 1910 , p. 66 .

80 Ladies' Home Journal, April, 1905, p. 95; April,

81Judith Rees and Carmi Weingrod, "The Bungalow Age," SLIDE-TAPE SHOW, Eugene, Oregon, September, 1980; The Bungalow Book Publishing Company, The Craftsman Book of Bungalows (Portland, Oregon: The Bungalow Publishing Company, $\mathrm{n} . \mathrm{d}$.) title page; Jud Yoho, p. 112; Ladies' Home Journal, February, 1908, p. 54. 
as others throughout the country, offered ready-cut homes:

The Fenner Manufacturing Company and the Western Division of Aladdin Homes. 82

Magazines and plan books helped to create middle America's taste for the bungalow and they promoted the new style so unremittingly that its appearance throughout the country would not have been surprising even if other factors had not contributed to its rise. Two of the plan book companies published their own magazines, both bearing the name, The Bungalow Magazine. They were published concurrently in 1912 by Henry Wilson in Los Angeles and the Bungalow Publishing Company in Seattle. 83

The bungalow prevailed as the style of the middle-class homeowner: the small town businessman or the well-paid urban laborer. As such, it was a builders' design, and few architects worked in the mode. But the bungalow had a pedigree; one of the important sources for its design was the Pasadena architectural team of Charles and Henry Greene. The Greenes created some truly innovative and inspired designs for the new homes of Pasadena in the early 1900's and their efforts contributed to the bungalow's development. As the bungalow moved to other parts of the country, however,

82 Fenner Homes of Distinction, p. 1; The Aladdin Company, Aladdin Homes: "Built in a Day" Catalogue No. 32 (Bay City, Michigan: The Aladdin Company, 1919), p. 3. 201. 83National Union Catalog: Pre-1956 Imprints, 84:200- 
its appeal lay in its simplicity and economy and the Greenes' contribution of honesty in design and craftsmanship was compromised; thus architects did not, for the most part, adopt the bungalow vocabulary. One plan book actually disdained architect-designed plans because they were theoretical and untested. 84 Fred Hodgson wrote that bungalows were not usually architect-designed because they were too inexpensive. 85 Saylor, on the other hand, thought that even though the bungalow was small and informal, it deserved the architect's skill.86 Some authors made a point of telling their readers that their bungalows were architect-designed. Jud Yoho, who was listed in a business directory as a real estate agent in 1905 and as a building contractor in 1911, called himself an architect in his 1914 plan book. 87 The Los Angeles Investment Company claimed that their supervising architect was licensed by the California State Board of Architects. 88 Some nationally-distributed bungalow catalogues were published by architectural firms; Lindstrom

${ }^{84}$ Gordon-Van Tine Company, Gordon-Van Tine's Grand Book of Plans for Everybody (Davenport, Iowa: Gordon-Van Tine Company, n. d.), p. 1 .

85 Hodgson, p. 8 .

86 Saylor, Bungalows, p. 55.

870 regon and Washington Gazatteer and Business Directory (Seattle: R. L. Polk \& Co., 1905-1906), p. 999; 1911-1912, p. 1109; Yoho, p. 112.

${ }^{88}$ Los Angeles Investment Company, Inexpensive Bungalows, p. 4. 
and Almars of Minneapolis published catalogues of plans, one of which featured exclusively bungalow designs, 89

Early yearbooks of the Portland Architectural Club of Portland, Oregon reveal that a few Northwest architects designed bungalows. The 1909 yearbook showed several: a Tacoma, Washington residence by M. H. Whitehouse and the Portland home of Amedee Smith by W. C. Knighton among them. 90 An example in 1910 was the D. A. Grout home in Portland designed by Knighton and Root.91 A one and one-half story stucco bungalow designed by Ellis F. Lawrence in Portland and the Bolina Jacobs house, a bungalow in Palmyra, Oregon by Johnson and Mayer appeared in 1913.92

The bungalow, then, was a style of domestic architecture which became a national phenomenon. Any attempt to define it precisely would not be complete without mention of the fact that some have viewed the bungalow as American architecture's first truly vernacular building style. Gustav Stickley, editor of The Craftsman and promulgator of bungalow appeal,

89Lindstrom and Almars; National Union Catalog: Pre1956 Imprints, $334: 491$.

90Portland Art Association and Portland Architectural Club, Yearbook: Second Annual Exhibition (Portland: IrwinHods on Company, 1909), pp. 66, 73.

91Portland Architectural Club, Portland Architectural Club Yearbook: 1910 (Portland: Irwin-Hodson Company, 1910).

92 The Architectural League of the Pacific Coast and the Portland Architectural Club, Yearbook, 1913 (Portland: IrwinHodson Company, 1913). 
did not approve of historical references in architecture; he wrote that ". . . each period must have its particular art."93 C. Matlack Price wrote that the bungalow may "yet be developed into a desirable and essentially American type of dwelling." He thought that the bungalow was one of only three types of American architecture which did not adhere to historical precedents. (The other two were secessionist architecture and Craftsman architecture.) 94 A contemporary plan book called the bungalow "the quintessence of the true art of home architecture."95 Insofar as the Greene brothers' work can be classified as bungalow architecture, latter-day critics concur with those who view the bungalow as vernacular architecture. In 1952, the American Institute of Architects cited the Pasadena architects for creating "a new and native architecture."96

In summary, the bungalow was a distinct style of architecture used extensively for American dwellings between 1905 and 1920. Its name was probably derived from the words of three Indian languages and adopted by English government agents who built temporary structures they called bungalows

93Gustav Stickley, "Thoughts Occasioned by an Anniversary: A Plea for Democratic Art," Barry Sanders, ed., The Craftsman: An Anthology (Santa Barbara: Peregrine Smith, Inc., 1978), P. 113.

94price, pp. 198, 202. p. 4 .

95Los Angeles Investment Company, Practical Bungalows,

96Esther McCoy, Five California Architects (New York: Reinhold Publishing Corporation, 1960), p. 146. 
on Indian travel routes. The characteristics of the bungalow style which evolved after its introduction in America were: horizontal lines, deep eaves, large porches with heavy supporting posts, exposed rafters and purlins, and textured natural building materials. Its interior expressed a free and open use of space. The bungalow quickly became a nationwide building style and from its beginnings in California soon found its way into the Northwest, Midwest, and East. Popular magazines and plan books offering mail-order blueprints and even ready-cut houses helped to promote the bungalow's popularity. Though a few architects worked in the style, the bungalow was primarily a builders' design, the home of America's middle and working classes. The bungalow may have been the first truly vernacular American domestic style. 
CHAPTER III

FACTORS WHICH INFLUENCED THE DEVELOPMENT OF THE BUNGALOW

The years which led into the bungalow period were years of change in middle-class American life. During the nineteenth century, the family had been modified both in structure and in purpose. Rapid industrial growth had disturbed community stability. During this turmoil, the home began to change. One of the products of this transformation was the bungalow. This chapter will examine how social and cultural change might have influenced change in America's houses.

SOCIAL CONDITIONS OF THE BUNGALOW AGE

Robert Wiebe, in The Search for Order, suggests that American values changed so rapidly that they produced social crisis during the nation's rapid growth between 1877 and 1920. America became a distended society and Wiebe thinks that the bigness encouraged the "standard of the overpowering."1 Disorientation with regard to proper moral conduct caused certain reactions: a community centering which occasioned a protective kind of prejudice, and

${ }^{1}$ Robert $H$. Wiebe, The Search for Order 1877-1920 (New York: Hill and Wang, 1967), Pp. 40-41. 
preoccupation with national, social, and personal purity. 2 Wiebe's conclusions were corroborated in contemporary 1iterature. The writer of a regular feature in the Ladies' Home Journal wrote in 1908: "We are living just at present in a very unstable era. Things are shifting about." 3 People sought moral clarity and national identity. Jane Addams, social reformer of Chicago's Hull House, wrote in 1907 that all institutions should engender proper values. 4 The popular histories written at the turn of the century reflect preoccupation with patriotism. The autobiographical sketches they included seemed overly concerned with American genealogy and valiant war records. ${ }^{5}$ This patriotism was reflected even in a movement promulgated by the periodicals of the time to encourage American women to buy Americandesigned clothes. Articles appeared admonishing women to reject the fashion dictatorship of Paris and to create their own American standards. 6

${ }^{2}$ Ibid., pp. 52-62.

'Ladies' Home Journal, February, 1908, p. 30 . 'Ladies' Home Journal, September, 1907, pp. 13-14.

5 The sketches in Charles Henry Carey's History of Oregon, 3 vols. (Chicago: The Pioneer Historical Publishing Company, 1922); Robert Carlton Clark's History of the Willamette Valley, 3 vols. (Chicago: The S.J. Clarke Publishing Co., 1927); and Joseph Gaston's The Centennial History of Oregon, 1811-1912, 4 vols. (Chicago: The S.J. Clarke Publishing Company, 1912) illustrate this point.

'6Ladies' Home Journal, August, 1909, p. 1; The Craftsman, January, 1910, pp, 464-467. 
The family itself underwent change during the period preceding the bungalow age. According to Carl Degler, the modern American family began to emerge at the beginning of the nineteenth century. The isolation of the nuclear family, its sense of privacy, and its separateness from larger society were characteristics which began to develop in the early 1800 's. During the colonial period, Degler writes, the extended family became less important and familial cohesiveness was focused in the nuclear unit. 7 Secondly, adults' view of children had begun to change. The child was no longer regarded as a small adult; instead, children were seen as innocents in need of careful instruction and socialization. For this reason, the rearing of young became a tremendously important responsibility. 8 Child-rearing approached a reform movement in itself, a process requiring constant vigilance, 9 This new emphasis on the importance of nurturing moral development in the child meant that the woman's role within the family became even more centralized in the home. Degler refers to this assignment of roles as the doctrine of two spheres and adherence to this doctrine had profound influence on women, their homes, and their

${ }^{7}$ Carl Degler, At Odds: Women and the Family in America from the Revolution to the Present (New York: Oxford University Press, 1980), pp. 3-25, 104-105.

${ }^{8}$ Ibid., pp. 66-67.

9 Wiebe, p. 19. 
relation to society. 10 So strong became society's view of woman as the caretaker of future generations that women who chose not to bear and rear young were severely censured. A Ladies' Home Journal article of 1907 accused women who were "deliberately childless," of "premeditated selfishness." A later issue scolded women who avoided childbearing for shirking a "grave duty."11 Perhaps this urging was thought necessary in view of the fact that the American birthrate was steadily declining. ${ }^{12}$ The American family was becoming smaller.

Since the important task of rearing children in a moral atmosphere fell to the woman, she was expected to forego other pursuits and to remain at home, a state of affairs which necessitated her complete financial dependence upon her husband.13 This doctrine was widely accepted in spite of the fact that some ripples of reform hinted at a move toward women's equality. Popular women's magazines advised women to rear their daughters as good housewives, to tend to the important work at home, and to refrain from entering the

10Degler, PP. 26-29.

${ }^{11}$ Ladies' Home Journal, January, 1907, p. 6 ; May 1 , 1911 , p. 28.

12 Degler wrote that the average number of children born to white women between the ages of 14 and 45 dropped from 7.04 in 1800 to 3.56 in 1900 and by 41 percent from 1900 to 1936 ; p. 181.

${ }^{13}$ Ibid., pp. 52-55, 26-37. 
workplace.14 McMinnville, Oregon's Telephone Register assured women readers in its regular "Home Circle Department" column that "all earthly pleasures are a mockery in comparison to the contentment of a loving home," which must be cherished with "infinite tenderness." In another "Home Circle" column, the writer said that the home is where women rose to their "truest heights."15 Charles W. Eliot, president of Harvard University, wrote that the normal woman did not clamor for intellectual pursuits outside her sphere. Marriage, he thought, offered intellectual stimulation enough. 16 If education were necessary at all, reports Degler, it must enhance the woman's primary role, that of wife and mother. According to Charles Richmond, president of Skidmore College, "One of the chief ends of college for women is to fit them to become the makers of homes."17

The early years of this century saw the emergence of a new discipline, home economics, or domestic science. Edith Allen credited the development of this new interest to women's clubs and to improved efficiency in the home.18 1913, p. $\frac{14 \text { Ladies' Home Journal, May, 1908, p. 5; February, }}{2 \text {; January, 1906, p. 19. }}$ 15 The Telephone Register, March 22, 1907, p. 3; March 29, 1907, p. 3; January 31,1908, p. 3.

${ }^{16}$ Charles W. Eliot, "The Normal American Woman," Ladies' Home Journal, January, 1908, p. 15.

17Quoted in Degler, pp. 314-315. 18Allen, pp. 123-125. 
David Handlin pointed out that increased knowledge of sanitation, health, and nutrition led to the new domestic science. He wrote that by 1900 over thirty universities offered it in their curriculums. 19 Allen found that Land Grant Colleges had taught home economics as early as the 1870 's. 20 By 1907 domestic science became a topic of general interest; McMinnville's Telephone Register covered a woman's club meeting at which it had been the subject of "1ively discussion."21 The Craftsman advertised homemaking as "the new profession" in 1908, and offered a home study course from the American School of Home Economics in Chicago. 22 The following year the American Home Economics Association was founded, answering, as Handlin argues, new needs created by changes in the social and economic functions of the family, 23 The Ladies' Home Journal suggested that home economics emerged as an answer to the "servant problem," that a scarcity of domestic help made it necessary for middle-class wives to return to the kitchen. ${ }^{24}$ In 1915 the Journal offered prize money for articles on domestic

19David Handlin, The American Home: Architecture and Society, 1815-1915 (Boston: Little, Brown and Company, 1979), Pp. 410-414.

20Allen, pp. 123-125.

${ }^{21}$ The Telephone Register, March 29, 1907, p. 8. 22 The Craftsman, August, 1908, p. v. 23 Handlin, pp. 410-411.

24Ladies' Home Journal, September, 1911, p. 83. 
science. 25 Women's work in the home inspired new inventions and technology made them possible. The electric vacuum cleaner appeared in advertisements in The Craftsman as early as 1908.26 This new convenience was advertised in The Telephone Register in 1909.27 Sewing machines, ironers, and pressure-driven washers made age-old tasks easier. Canned and packaged foods reduced the time spent in preparation of meals. 28 Domestic science, by easing housekeeping chores, contributed to the bungalow's popularity, for one of the bungalow's major innovations was that it simplified home maintenance.

The bungalow's popularity was associated with the trend toward homes without servants. The caption under a modest 1908 bungalow claimed that "with a compact little home like this an orderly housewife can easily keep it looking trim and neat with very little work."29 A 1910 article featuring small bungalow plans was entitled, "For the Bride Who Does Her Own Work."30 Magazine advertisements suggested that in the home, women performed even those tasks which, in the

${ }^{25}$ Ladies' Home Journal, November, 1915, p. 86.

${ }^{26}$ The Craftsman, November, 1908, p. xxvii.

27 The Telephone Register, September 10, 1909, p. 6 . 28 See the Ladies' Home Journal, May, 1908, Pp. 41, 54 , 69; July, 1910, pp. 27, 61.

${ }^{29}$ Ladies' Home Journal, May, 1908, p. 33.

30Ladies' Home Journal, October 1, 1910, p. 37. 
professional world, would have been men's; paint and varnish advertisements consistently pictured women with paintbrushes in their hands. 31 These indicators suggest that women in the early 1900's had decision-making powers within the purview of the home. Advertisements for house plans, paints and varnishes, even iron fencing, appeared in periodicals designed specifically for the woman reader. An article on homebuilding in 1908 was subtitled, "An Architect's Frank Talk with the Man or Woman Who Is About to Build." Another featured a house built by two bachelor girls. 32 The following year, The Craftsman ran a piece about an Illinois woman who had devised several clever innovations which she had incorporated into her new home. 33 These may have been exceptions, however. 34 The writer of one Ladies' Home Journal article which featured a bungalow wrote that the bride's father had designed and built the home for his daughter while she was away on her honeymoon. Her only injunction had been that there was to be a large porch. The father was responsible for the decisions to open up the interior spaces, to expose

${ }^{31}$ Ladies' Home Journal, May, 1908, pp. 55, 62; Apri1, 1909 , p. 65 ; June, 1913, p. 43.

32Ladies' Home Journal, April, 1908, p. 28.

33 The Craftsman, November, 1910, pp. 197-199.

34 In spite of this picture of women designing their homes to suit their homemaking needs, a later chapter of this paper will show that evidence does not always substantiate this perception. 
structural timbers, and to put the living room windows on the street side of the house. 35

As homes began to run more efficiently, middle-class women began to get involved in reform issues which fought immorality and injustice. According to Degler, these activities, even though they took women out of the home, were considered proper to the feminine role; they conformed to the doctrine of two spheres. 36 The move toward forming women's organizations swept the nation during the twentieth century's first decade. By 1914, the General Federation of Women's Clubs had one million members. 37 Women were having fewer children and due to efficient homes, were experiencing more leisure time than ever before. The clubs were not all forces for change, but many were. The Young Women's Christian Association, formed in Boston in 1866 for working girls; New York's Women's Trade Union League formed in 1903; and the Consumers' League, a Massachusetts-based organization dedicated to improving wages and working conditions were groups organized to improve the human condition. Purely social organizations multiplied as well. The Ancient Order of Eastern Star, the Women's Relief Corps, P. E. O., and the

${ }^{35}$ Ladies' Home Journal, April, 1909, p. 27.

36 Degler, pp. 298-304.

37 Degler, p. 151. 
Daughters of the American Revolution were all formed between 1876 and the turn of the century. 38

Women's clubs were not well received in all quarters; some believed they were taking the woman too far from her assigned role in the home. Edward Bok, editor of that vigilant guardian of the doctrine of two spheres, the Ladies' Home Journal, wrote a scathing editorial in 1910 chastising women's clubs for giving women only superficial knowledge which was dangerous for their children. The clubs may have been responsible for child labor laws, juvenile courts, and libraries, he wrote, but they had not dealt with the social ills he saw as urgent: divorce, venereal disease, sex education, and health. ${ }^{39}$ A year later, continuing his campaign against the "club woman," Bok wrote that women should not enter the world of affairs just because their work had been made easier by modern invention, but that they should stay home and train their children. 40 So great was the club movement, however, that by 1913, Bok had acknowledged its place in society and the Journal instituted a monthly colum entitled, "What Women's Clubs Are Doing."41 Women's clubs offered a perfect forum for the civic improvement campaign fostered by town planning. The concept

${ }^{38}$ Ibid., pp. $322-324$.

${ }^{39}$ Ladies' Home Journal, January, 1910, p. 1. ${ }^{40}$ Ladies' Home Journal, September, 1911, p. 5. 41 Ladies' Home Journal, January, 1913, p. 1. 
of city planning had developed by 1900 and like domestic science, had become an accepted course of study by the time the bungalow emerged. In 1909 the first national conference on city planning was held in Washington, D. C., and that same year, America's first college course was offered on the subject at Harvard. 42 This growing interest influenced the way land was developed and Handlin cites several instances of planned neighborhoods between 1905 and 1915.43 Planning indicated a concern with the physical aspects of the community environment and a keen interest in civic improvement was a result of this trend. During 1910 The Craftsman published two articles dealing with civic improvement and the women's clubs whose cause it had become. 44 The Ladies' Home Joumal often ran articles which featured before and after photographs of community beautification projects: park improvement, roadside plantings, trash collection, or billboard removal. 45

One of the issues of the early 1900's most likely to affect the American home was that of equality between the sexes. The woman suffrage battle was in progress and more women than ever before were joining the work force between 42Handlin, pp. 143-144. 43 Ibid., pp. 183-185. 44The Craftsman, January, 1910, pp. 425-427; November, 1910, pp. 149-153. 45See the Ladies' Home Journal, January, 1914, p. 22. 
1900 and 1920. It had not been until the middle of the nineteenth century that women were accorded the privilege of higher coeducation. In 1837, Oberlin College in Ohio was the first men's learning institution to open its doors to women. The first quality women's colleges were not established until the 1850 's. 46 In its customary spirit of reform, The Craftsman exhibited support of equality by training both boys and girls at its Craftsman Farms. 47 Thus, a measure of recognition was given women in the field of education, but equality in the family was harder to attain. Degler claims that woman's position in society could never be elevated until her position in the family changed, and early twentieth-century feminists agreed. Good Housekeeping seriously questioned the doctrine of two spheres in articles like, "The New Marriage," a position paper on reasons for allowing women pursuits outside the home. 48 Even the more conservative Ladies' Home Journal found that it must recognize the existence of feminism by 1914; two fictional series entitled "Ruth Grenville--Feminist: Her Adventures in the City That Doesn't Care," and "A Free Woman: My Own Story of My Emancipation," began in the August issue of that year. 49

46 Degler, pp. 310-311.

47 The Craftsman, October, 1908, p. ix.

${ }^{48}$ Good Housekeeping, February, 1914, p. 181.

49 Ladies' Home Journal, August, 1914, pp. 3, 7. 
Implicit in the movement for equality on the home front was equal opportunity in the workplace. The W.C.T.U. called for "equal wages for equal work without regard to sex" in 1907. 50 By 1909 the number of working girls in urban centers prompted the secretary of the Consumers' League to write a piece on the difficulty of their economic situations. 51 The Craftsman featured articles on women farmers, women illustrators, and women sculptors. 52

The other side of this picture of working women was that in spite of the publicity devoted to equality in the workplace, or to bachelor girls and woman farmers, the fact remained that no more than five percent of the married, white, female, American population worked outside the home in 1910.53 If single women worked, it was, in most cases, because they had to and conversely, if they chose to work or to develop careers, they did not marry. Degler found that three-fourths of all American women who earned $\mathrm{Ph} . \mathrm{D}$, degrees between 1877 and 1924 remained single.54 If women worked, there were limited fields from which to choose; millinery, catering, flower-raising, needlework and dressmaking, or

${ }^{50}$ The Telephone Register, April 26, 1907, p. 5. ${ }^{51}$ Ladies' Home Journal, November, 1909, p. 15. 52 The Craftsman, July, 1910, pp. 472, 475, 476. 53 Degler, p. 81. 54 Ibid., p. 385 . 
teaching were considered fitting. 55 Married women could take in boarders. 56

Woman suffrage was perhaps the most historically significant of the New Woman's issues, but in the early years of the century, it received a great deal of negative publicity from women themselves. Margaret Deland, writing about the New Woman in 1907, denounced the suffrage movement.57 A story disparaging women's ability to vote intelligently appeared in the Ladies' Home Journal in 1910 and that same year the Journal reaffirmed its editorial policy opposing woman suffrage. 58 Not all-women's magazines held this view; both Good Housekeeping and the Delineator were officially in favor of woman suffrage. 59 In 1914 Good Housekeeping ran a rousing series of articles advocating militancy by British suffragette, Emmeline Pankhurst, 60 By 1913 even the Ladies' Home Journal was publishing pro-suffrage pieces. 61

55Ladies' Home Journal, February, 1908, p. 40. 56Degler, p. 393.

57Ladies' Home Journal, September, 1907, p. 17.

58Ladies' Home Journal, August, 1910, p. 4; November 1, 1910 , p. 15 .

${ }^{59}$ Good Housekeeping, January, 1914, advertising p. 6; The Delineator, August, 1910, p. 5.

${ }^{60}$ Good Hous ekeeping, January, 1914, p. 4.

${ }^{61}$ See the Ladies' Home Journal, June, 1913, p. 21. 
These were the signs of social change, then, when the bungalow style appeared in American domestic architecture. In great measure, middle-class women spearheaded certain aspects of this change. They found the means to work in reform through organizations which took them outside their homes. Concurrently, questions about the role of woman herself became reform questions. Equality, suffrage, and the right to work were matters addressed in contemporary periodicals. Perhaps social changes were reflected in the changes people made in their personal environment, in the house. Certainly, the bungalow style represented change. Its open floor plan placed household members more closely in touch with one another and its simple interior made housekeeping easier. These innovations very probably affected family life. We will examine next American middleclass cultural changes which more specifically affected the home.

FACTORS IN THE HOME WHICH INFLUENCED BUNGALOW DEVELOPMENT

The house reflects cultural values. Basic to middleclass American society is the nuclear family and the family's needs, habits, and tastes must all be answered in the design of its immediate environment, the house. According to Karen Current, since Andrew Jackson Downing developed his philosophy of domestic architecture in the nineteenth century, the house has fostered what is virtuous in human beings. It provided respite from the complexity, grime, 
and evil of the industrialized world. It also represented aspiration; owning a detached house became the goal of the middle-class American family. 62 For this reason, economy became an important factor in house design.

Henry Glassie has seen the house as the means through which one member of society relates to the other members. The inhabitant sees his house as an extension of his personality, 63 David Handlin points out that home ownership for the American working class was becoming an ideal by the middle of the nineteenth century. 64 But providing beautiful homes for more and more people became an economic problem, so cheaper construction methods were developed. 65 Thus, home ownership as an ideal was probably a significant factor in the evolution of style.

A growing taste for informality created the need for a domestic style which could accommodate comfort and simplicity, One architectural historian, quoted in The Seattle Post-Intelligencer, calls the bungalow "the first informally hospitable house in America."66 A 1914 article in House Beautiful entitled, "Bungalow Entertaining," implied that a

62 Current and Current, p, 1.

63 Henry Glassie, Folk Housing in Middle Virginia (Knoxville: University of Tennessee Press, 1975), P. 116.

64 Handlin, p. 71.

65 Ibid., pP. 235-237.

${ }^{66}$ The Seattle Post-Intelligencer, January 17, 1981 , sec. C, P. 3 . 
bungalow was a place where intimates in small numbers could be entertained without ceremony. 67 Karen Current sees the bungalow as the answer to the desire for a simpler life; she writes that it symbolized comfort in place of luxury and reflected the conservative values of the new middle class of the early 1900's.68 An architectural critic in 1921 attributed the bungalow's popularity to its adaptability, simplicity, and convenience. 69 In 1908 a plan book offered its bungalow designs as alternatives to inconvenient, boxy houses with high ceilings. 70 Two interviewees in McMinnville, Oregon remembered life style changes that coincided with bungalow design; one remembered that the family sat together more in the bungalow living rooms and another remembered that both in his native Wisconsin and in Oregon, people liked to sit on the ample bungalow porches. 71 One technological advance which enabled change in house design was the central heating system. Furnaces not only made the basement roomier and more comfortable, they also made general

67 House Beautiful, June, 1914, pp. 18-19.

68 Current and Current, p. 5.

$69_{\text {Boyd, p. } 3 .}$

70 The Bungalow Plan Company, The Bungalow Plan Book

(Los Angeles: The Bungalow Plan Company, 1908), p. 3.

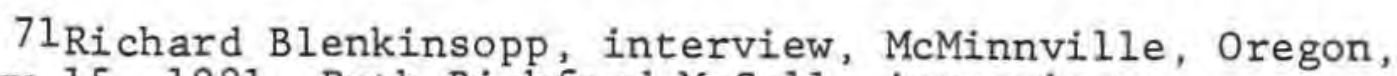
January 15, 1981; Ruth Bickford McCal1, interview, McMinnville, Oregon, January 15, 1981. 
use of the entire house possible, and rooms could be opened into one another to create larger spaces. 72

The function of the house did change at the time that the bungalow became popular. Handlin wrote that nineteenthcentury Americans had been ambiguous in their use of interior space. On the one hand, they sought the culture and civilized life style implied in separate spaces for different, formalized functions; on the other, they saw that this fragmented family life.73 After several decades of living in these separated spaces, there is some evidence that the American family wished to return to a single hearth. An article in a 1906 issue of the Ladies' Home Journal contains the following:

I remember with pleasure the blessed sense of sharing the warmth of one room with a fire in it at my old home. 74

The first casualty in this opening up and sharing of space was the formal parlor. Houses of the Victorian era had already made use of sliding doors which could open to connect two rooms. Henry-Russell Hitchcock wrote that the opening together of two rooms by this means was a planning innovation which appeared as early as the 1790's,75 A 1908 magazine article on planning interior space suggested

72 Allen, p. 105.

73Handlin, pp. 343-354.

74Ladies' Home Journal, January, 1906, p. 34.

75 Hitchcock, p. 256. 
eliminating both the long hall from the kitchen and the parlor, making instead a larger living room. The idea was to "reduce your building to the simplest terms consistent with your life." A 1911 article contained the sentiment that the parlor was useless and expensive; that the best room in a house should be for the use of the family. 76 Boyd wrote in 1921 that Americans had outgrown the "thralldom of that veritable chamber of horrors, the parlor. . ."77 Plans for removing the wall between parlor and sitting room in older houses were offered in magazines, and as one writer pointed out, "Space which was formerly given up to the parlor. . . of so little use, now becomes the living room making it twice its original size."78 The earlier plan books of the period reflected a transitional interval. Fred Hodgson's 1906 book, Practical Bungalows and Cottages, contained Queen Anne houses which were turreted, crested, and spindled; yet some of his plans were true bungalows. His more traditional houses had traditional interior plans of separate, closed rooms; the bungalow designs had interiors truer to the bungalow aesthetic. 79 Figures 7 and 8 illustrate similar designs from Radford's Artistic Bungalows. 1911 , p. $\frac{76 \text { Ladi }}{47}$

76Ladies' Home Journal, April, 1908, p. 28; January 1 , 77 Boyd, p. 4. 78 Ladies' Home Journal, November, 1910, p. 83. ${ }^{79}$ See Fred Hodgson's Practical Bungalows and Cottages. 


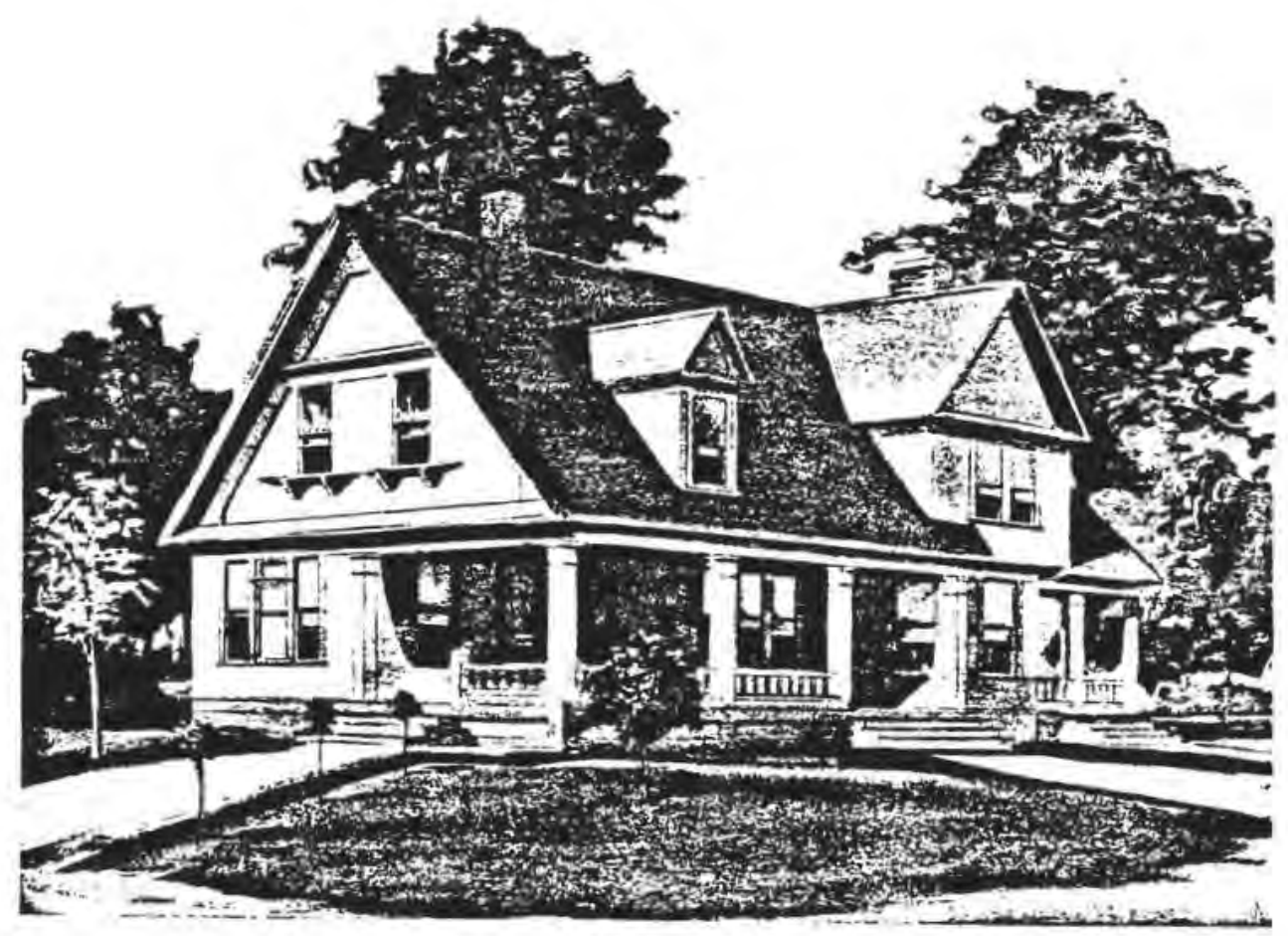

\section{Design No. 2546=B}

Size: Width, 35 feet; Length, $6 \mathrm{t}$ feet

Blue prints connist of cellur and foundation plan; roof plan; tloor plan; front, rear, two sile elevations; wall sections and all necesary in. terior details. Specifications conaist of twenty-two pages of typewritten matter.

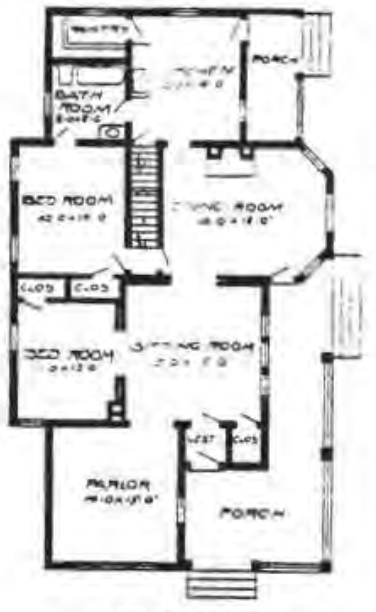

Foor Plan

\section{PRICE}

of Blue Priges, Together mith a complere set at ivperritten specifications

\section{ONLY \\ $\$ 10.00$}

We mail Plans and Specio. eations the samn day oriler is reeciseil.

Figure 7. A traditional house from Radford's Artistic Bungalows with a traditional, closed room floor plan, p. 177. 


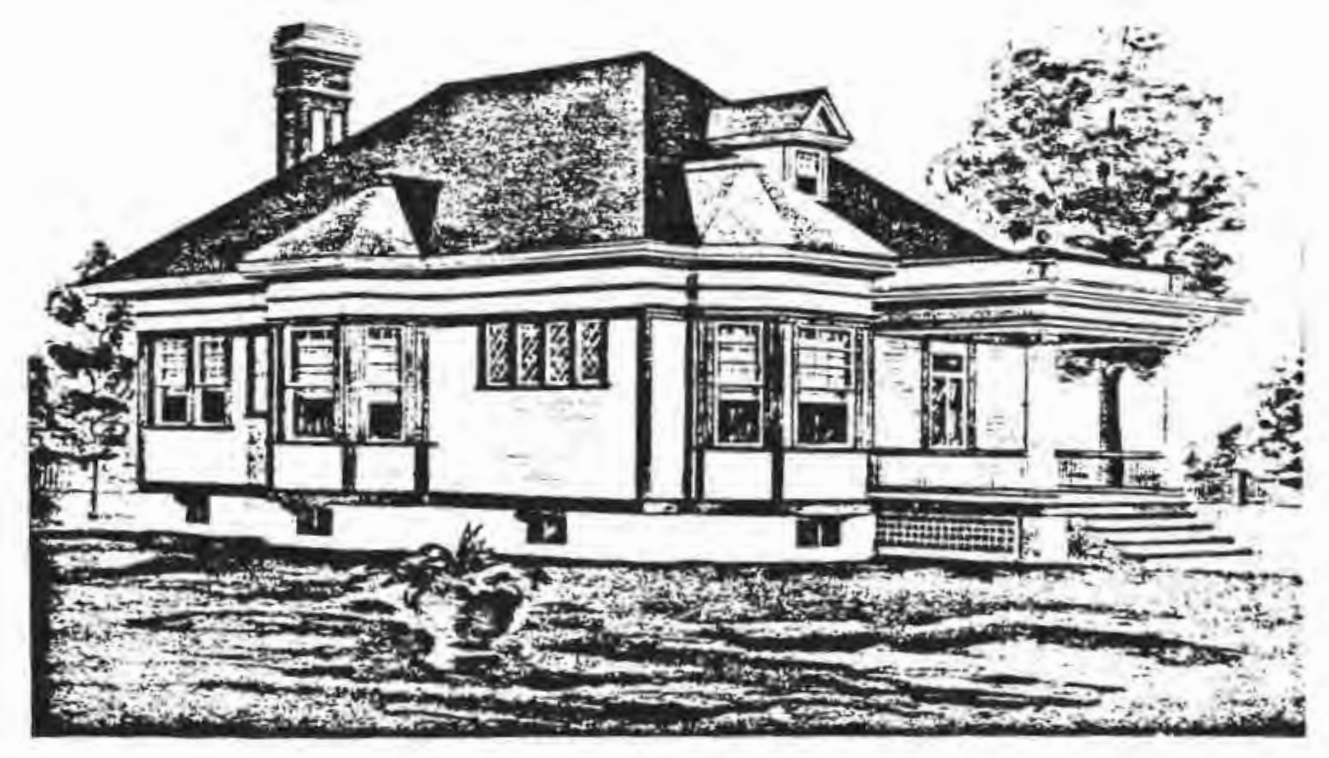

\section{Design No. 5045}

Size: Width, 3 I feet; Length, 47 feet

Blue prints eonsist of foobda. tion plan; attic and roof plans: floor plan; front, rear, two side elecations; wall sections and all necessary iaterior details. Spec. ifications consist of twenty-two pages of typexritten matter.

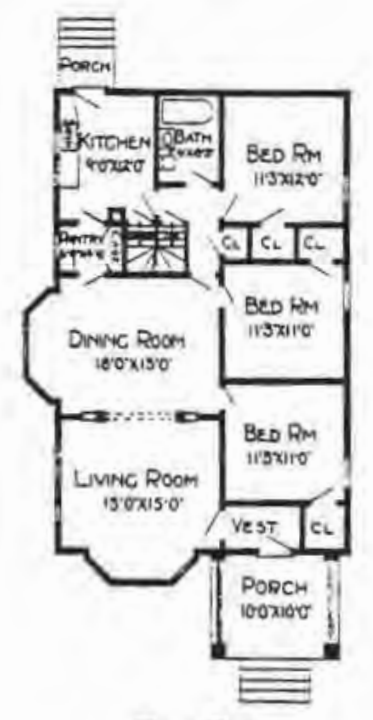

Floor Plen

\section{PRTCE}

of Blue Prints, topetber wirti n coniplete set of typewritten sitwe ifieatious

$$
\text { ONIT }
$$

\section{$\$ 10$ :00}

We maid Plans anol siwriffra. tions the same day oriet is re. eriverl.

Figure 8. A bungalow with an open living room dining room floor plan from Radford's Artistic Bungalows, p. 175. 
Writers contemporary with the bungalow promoted simplicity in ornament. Henry Saylor thought the "bungalow . . cries out for the simplest possible treatment in ornamentation." Sturdiness, simplicity, and economy were suggested for its furnishings. 80 Natural wood finish was preferred. The Ladies' Home Journal advocated honesty in decor.81 A 1914 House Beautiful article features bungalow interiors which emphasized natural wood beams and wood paneling. 82 In keeping with honest design, the periodicals promoted simplicity even in small items used to decorate the home. Magazines published articles showing how to pare the curves and carving from old furniture; how to crochet in the geometric filet style; how to make rag rugs; and how to replace swags, jabots, and portieres with simple cloth curtains. 83 The unpretentious bungalow, wrote the author of a 1914 article, requires natural, simple materials for its ornamentation: grasscloth, canvas, burlap, jute, and linen. 84 Simpler decor meant simpler housekeeping. This surely attracted the woman who kept no domestic help.

80 Saylor, Bungalows, pp. 149, 156.

${ }^{81}$ Ladies' Home Journal, September 1, 1910, p. 64. 82 House Beautiful, June, 1914, pp. 26-27.

${ }^{83}$ Ladies' Home Journal, November, 1909 , p. 29 ; September, 1914, p. 31; January 1, 1911, p. 27; February, 1906 , P. 33.

84 House Beautiful, June, 1914, pp. 24-26. 
A taste for simplicity was but one element influencing bungalow design; as noted previously, the need for economy was another. Many writers attributed the bungalow style's great popularity at least in part to low building costs. Henry Wilson wrote in 1910 that the bungalow represented the marriage between economy and art in architecture. 85 A recent authority quoted in a Seattle newspaper argues that the bungalow was cheap enough to build that it enabled the middle class to buy homes in great numbers fulfilling the aspiration to home ownership. He attributed low cost to the plan books and builders who published them. 86 Allen wrote that as builders began to construct numbers of houses of one design, standardization resulted and this lowered costs. 87 She also referred to the catalogues and ready-cut houses as factors in lowering building costs. 88 If the builders' bungalow was inexpensive, part of the reason was undoubtedly reduction in floor space--smaller kitchens and combined living spaces. Plan books of the period showed a wide range in costs. The Bungalow Plan Book from 1908 showed plans which cost from $\$ 600$ to $\$ 2,200$ to build;

85 Wilson, p. 3.

86 The Seattle Post-Intelligencer, January 17, 1981, sec. C, P. 3 .

$$
\begin{aligned}
& 87 \text { Allen, p. } 162 . \\
& 88 \text { Ibid., p. } 159 .
\end{aligned}
$$


Keith's Bungalows and Cottages showed houses ranging in price from $\$ 400$ to $\$ 2,500.89$ In 1913 the Ladies' Home Journal advertised eight designs costing from $\$ 720$ to $\$ 3,000$. Jud Yoho's bungalows could be built for prices from $\$ 400$ to $\$ 4,000$ in 1914.90 Average construction costs of bungalow designs found in The Craftsman magazine tended to be slightly higher than those in the plan books; a 1909 article featured six ranging from $\$ 2,800$ to $\$ 3,800.91$ Balloon construction techniques, universally employed in bungalows, have already been cited as an economical innovation.

The opposing view concerning bungalow economy was set forth by Henry Saylor in 1910 when he wrote that the bungalow was not cheap because a one-story house with the same floor space as a two-story house required more roof. ${ }^{92}$ Boyd agreed; he cited not only increased roof area but the need for a larger lot as we11.93 With regard to the argument that lumber was cheap, McMinnville's Telephone Register published an article in 1908--early in the bungalow era-which warned that timber consumption was probably three

${ }^{89}$ See the Bungalow P1an Company, The Bungalow P1an Book; Bungalows and Cottages (Minneapolis: Max Keith, Publisher, n.d.).

, 90Ladies' Home Journal, July, 1913, p. 31; Yoho, Craftsman Bungalows.

${ }^{91}$ The Craftsman, August, 1909, pp. 576-579.

92Saylor, Bungalows, p. 63 .

93 Boyd, p. 5. 
times greater than regrowth. ${ }^{94}$ More telling than these arguments was the choice of architecture used by the United States Housing Corporation when it built $\$ 100,000,000$ worth of emergency wartime housing in 1918. The architectural division of the corporation cut costs by narrowing baseboards and moldings, minimizing eaves, and eliminating extra doors and windows. At the height of the bungalow's popularity, the corporation, whose major concern was economy, did not choose to build in the bungalow style. 95

This discrepancy in views about the bungalow's economy must be attributed to the wide variety of houses found in the bungalow style. If an architect were employed to design a large, elaborate house, the cost would be rather high. If a simpler design were chosen from a plan book and if a builder who could use the plan more than once were employed, building costs could be kept quite low.

The house shelters the very nucleus of middle-class American culture and can reflect change in that culture. During the early years of the twentieth century, the detached, single family dwelling underwent change which was concurrent with change in society itself. Social, cultural, and economic factors appear to have helped to bring this shift about. Perhaps just as profound in their effects upon

94 The Telephone Register, January 24, 1908, p. 1. 204.

95United States Housing Corporation, 1:7, 61-74, 183, 
American house design, were the new ideas being promulgated by the architects, artisans, and builders of the period.

\section{FACTORS WHICH INFLUENCED BUNGALOW DESIGN}

Bungalow design has been attributed to many sources: historical precedents, individual architects working at the turn of the century, the widespread Arts and Crafts Movement, and foreign influences. Historically, Andrew Jackson Downing and his promotion of fitness in domestic architecture had one of the most profound effects on subsequent house building in America.

Andrew Jackson Downing introduced a trend toward the use of natural elements and probably influenced what was later referred to as organic architecture.96 Downing was born in 1815 on the Hudson River in New York. As a nurseryman, he began publishing books on horticulture in 1841 . Writings on architecture followed and his last and most widely-read publication, The Architecture of Country Houses, popularized Downing's philosophy of domestic architecture. 97 Downing's precepts were influential generations after his death and his philosophy was echoed over and over: in the work of Frank Lloyd Wright, in the Chicago School, in the Arts and Crafts Movement, even in the books of bungalow plans.

96 Current and Current, P. 2.

$97 \mathrm{~J}$. Stewart Johnson, introduction to The Architecture of Country Houses by Andrew Jackson Downing (New York: Dover Publications, Inc., 1969), pp. v-x. 
Downing's axioms included the following: a house should serve its purpose; it should express beauty in picturesque terms; it should be true to structure, use, and materials; and above all, it should be fitting. 98 The influence Downing wielded even into the time of the bungalow builders was obvious in early twentieth century writings. Wilson boasted that his designs fit the exterior to the preconceived floor plan rather than the reverse. Saylor suggested using colors compatible with nature's own and relating the house to its environs. The author of Radford's Artistic Bungalows calls the bungalow "the result of the effort to bring about harmony between the house and its surroundings." C. Matlack Price advised suiting style to location and using appropriate materials.99 Architect Aymar Embury, writing in 1909, repeated several of Downing's precepts. He wrote that all good modern architecture should exhibit honest expression of plan and structure, show the characteristics of the building materials, and relate the structure to the grounds. 100

A nineteenth-century giant in American architecture was Henry Hobson Richardson, remembered chiefly for developing, during the 1870 's and $1880^{\prime}$ 's, the Richardsonian

98Downing, pp. 3-38.

99 Wilson, pp. 3-4; Saylor, Bungalows, pp. 48, 54; Radford's Artistic Bungalows, p. 3; Price, pp. 225-243.

100 Aymar Embury II, One Hundred Country Houses (New York: Century Company, 1909), pp. 14-15. 
Romanesque style widely used for large public buildings. 101 Richardson, a prolific designer, also worked in the domestic arena and developed an open, flexible, and informal interior plan in his distinctive Shingle Style houses. 102 This was to influence later architects Frank Lloyd Wright and the Brothers Greene, both of whom influenced bungalow design. According to $\mathrm{H}$. Allen Brooks, the work of Frank Lloyd Wright and his Prairie School of architecture was very close to the Arts and Crafts Movement, a decided influence on bungalow design as we will see later.103 Wright had designed a home for the Ladies' Home Journal in 190.1 at the request of editor, Edward Bok. 104 Karen Current hypothesized that Wright's plan was too lofty for the middle-class reader of the Journal; Wright did not furnish many more designs for the magazine.105 But Lancaster thought that Wright made an inestimable contribution to the bungalow vogue with his prairie houses. Lancaster saw similarities in the broad, hipped roofs and low horizontal profiles.106 As pointed out

101 Hitchcock, pp. 227-232.

102 Current and Current, p. 3.

103 H. Allen Brooks, The Prairie School: Frank Lloyd Wright and His Midwest Contemporaries (New York: W. W. Norton and Company, Inc., 1972), P. 17.

104Milton W. Brown et al, American Art: Painting, Sculpture, Architecture, Decorative Arts, Photography (New York: Harry N. Abrams, Inc., 1979), p. 268.

105 Current and Current, pp. 9, 11. ${ }^{106}$ Lancaster, Art Bulletin, p. 250. 
earlier, Saylor had related the Prairie School to the bungalow and Brooks maintained that Wright's clients saw the prairie house as a type of bungalow. 107

The architectural team to have the greatest influence on bungalow design was probably that of Charles and Henry Greene who practiced in Pasadena, California from 1894 until well into the twentieth century. The Greene Brothers had a firm background in craftsmanship; they had studied at Washington University's Manual Training High School and at Massachusetts Institute of Technology, 108 Although their early work showed the influence of classical training, by 1903 they were beginning to develop a distinctive style of their own. With the construction of the Bandini House, a low, sprawling structure influenced by the California haciendas, the Greenes built the first house which exhibited their special signatures. 109 The Greenes expressed structure through the use of brackets, beam ends, trusses, corbels, and exposed rafters. Karen Current cited two sources of inspiration for this structural expressiveness: the English halftimber frame and the Japanese cage, 110 Many of their hallmarks--overhanging eaves with exposed rafters, sheltered porches, pergolas, and horizontal lines--became the

107 Brooks, pp. 20-21.

108 Current and Current, p. 2.

${ }^{109}$ Ibid., PP. 13-14.

110 Ibid., pp. $35,34,12-13$. 
characteristics of the bungalow style, 111 There has been reluctance among architectural historians to apply the term bungalow to the Greenes' houses because they were usually large and of superb craftsmanship. John Blumenson and Marcus Whiffen both place Greene houses in a classification they call the Western Stick Style, the characteristics of which are also those of the bungalow: horizontality, projecting eaves, brackets, and porches or verandahs. 112 Clay Lancaster points out, however, that contemporary critics called Greene houses bungalows. 113 The Greenes' houses exhibited exquisite craftsmanship. The architects themselves often designed the entire house including woodwork, glas,, fixtures, fumiture, even rugs. Charles Greene made many of the fumishings for their commissions. 114 It is believed that they were influenced by a movement concurrent in America with their own significant work, the Arts and Crafts Movement. Much of their interior work exhibits Arts and Crafts elements: inglenooks, window seats, and focal fireplaces. 115 The Craftsman, voice of America's Arts and Crafts

111McCoy, Pp. 104-105.

112Blumenson, PP. 56-57; Whiffen, PP. 209-212.

113Lancaster. The Japanese Influence in America, p. 111. 114Current and Current, pp. 40-41. 115 Ibid., p. 40. 
Movement, praised the Greenes' work as national, indigenous architecture, 116 (See Figure 9,)

The Arts and Crafts Movement in America is considered by some to be the most important influence on bungalow design. It began in England with the ideas of William Morris, midnineteenth century artist-socialist. Morris had studied the Middle Ages and had evolved the idea that only under a socialist system could popular art flourish. He became a decorator and established the firm, Morris and Company which conducted business in the $1860^{\prime} \mathrm{s}$ and $1870^{\prime} \mathrm{s}$. He wanted to form a brotherhood of craftsmen and to revive the arts and crafts of the Middle Ages. The firm practiced all the decorative arts, and their designs were to enjoy popularity in America nearly half a century Iater, 117 The Ladies' Home Journal featured a full page of "The Famous William Morris Designs in Stencil" for embroidery in 1911.118

Morris'best known disciple in the United States was Gustav Stickley, son of a Wisconsin stone mason. Stickley established a furniture factory in Binghamton, New York, in 1884.119 Like Morris, he sought to elevate the popular arts and to simplify life, making art available to all.

116 The Craftsman. Apri1, 1909, p. 83.

117Irene Sargent, "William Morris," The Craftsman: An Anthology, pp. 7-11.

118 Ladies' Home Journa1, March 1. 1911, p. 78.

119 Russe11 Lynes, The Tastemakers (New York: Grosset and Dunlop for The Universal Library, 1954), P. 187. 


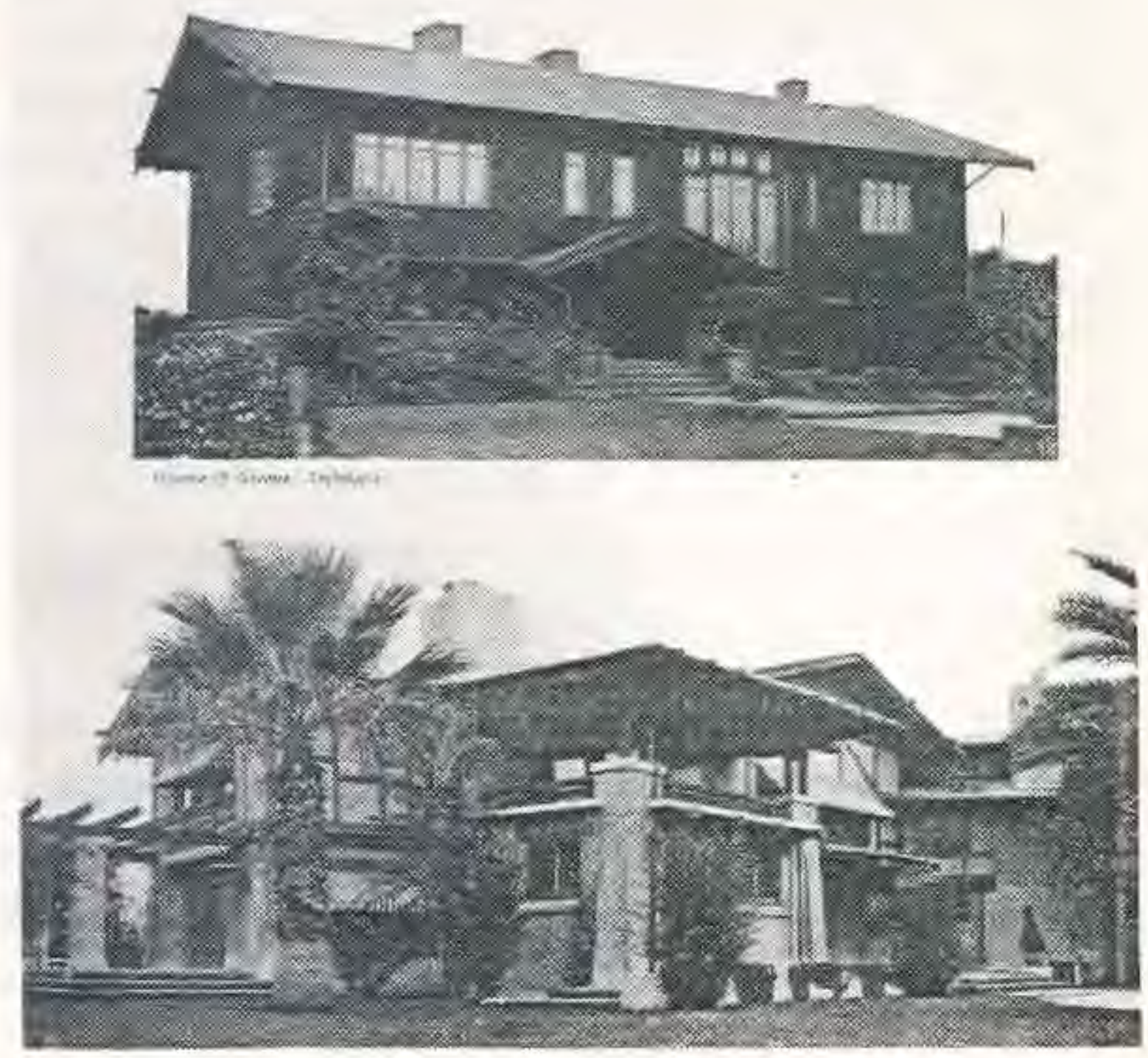

Figure 9 Two Greene and Greene houses which appeared in The Craftsman. April, 1909, p. 83, 
In 1901 he established a voice for his Arts and Crafts Movement, The Craftsman magazine, which he published until 1916.120 In the beginning, the magazine espoused socialism; printed on the covers of early issues were the words: "Published in the Interests of Art and Labor."121 The magazine's concern, Stickley wrote, was "better art, better work, and a better and more reasonable way of living," Stickley, too, admired the craftsmen of the Middle Ages and sought to encourage modern trade unions to return to the tactics of medieval guilds in protecting their members, 122 The magazine carried articles on a wide variety of social issues and on all the arts. Examples are, "With Maxim Gorky in the Adirondacks," "Germany's Practical Method of Caring for Children of the Poor," and "Ethics and the Ring of the Niebelung."123 Woodcarving, pantomime, photography, town planning, and the dance were all subjects treated in the pages of The Craftsman. 124 Stickley developed designs in a wide variety of crafts. Needlework, basketry, metalwork, even wallpaper designs and rugs, were sold through Craftsman

120Barry Sanders, pp. vil-viil.

121 The Craftsman, January, 1903, cover.

122 The Craftsman, February, 1907, p. v; January, 1908. pp. $375-384$,

${ }^{123}$ The Craftsman, November, 1906, pp. 149, 223: October, 1906, P. 3 .

124 See The Craftsman, May, 1909; March, 1910; April, 1909 , October. 1908 . 
fumiture factories. 125 In 1908 Stickley opened a school where his purpose was to educate young people in the craftsman traditions, 126 Design promoted by The Craftsman was simple and expressive of labor. Fabrics were stenciled with either geometric shapes or simple, stylized floral patterns and rugs were often woven in geometric Indian patterns. 127 With regard to the building crafts, Stickley thought that since America's genius was structural, structure should always show and materials should be native products. 128

In 1909 Stickley published an article entitled, "A Plea for True Democracy in the Domestic Architecture of America," wherein he set forth his ideas about the requisites for a good house, He wrote that a house must suit individual needs, it must be designed by an architect who could be sensitive to these needs, and meet them with proper design, and it must be built by craftsmen who were able to execute good design. 129 Stickley also wanted Americans to create a

125 The Craftsman, August, 1906, p. 676; February, 1908, p. xv, xxili; November, 1908, P, xxxv.

126 The Craftsman, October, 1908, p. ix.

127 The Craftsman, November, 1906, pp, xxxi1, xxxili; February, 1908, p. xxil; December, 1908, p. xxxi.

128 Gustav Stickley, "Thoughts Occasioned by an Anniversary," p. 119.

129 The Craftsman, June, 1909, p. 251. 
national architecture, an architeccure no longer dependent on historical precedents, 130 In the first years, the magazine did not offer house designs in every issue but by 1903, Craftsman house plans were becoming a regulat feature. Perhaps because of the close association to the English Arts and Crafts Movement, these houses were often fashioned in half-timber designs, 131 Stickley also showed a great deal of stucco and cement, and his houses were often two-story. (See Figure 10.) By 1905 The Craftsman was designing some houses which had bungalow elements. A 1905 Craftsman cottage has a wide sweeping roof, sheltering a full-width verandah, and by 1909 designs for this same type of house were showing the bungalow's exposed rafters and deep eaves. 132 (See Figure 11.) If Stickley's craftsmen did not themselves design primarily bungalows, they often featured articles about architects who did, and thus promulgated the bungalow style among followers of the Arts and Crafts Movement. 133 Barry Sanders found these followers to be substantial in number; he wrote that in 1915 , over $\$ 20$ million worth of

${ }^{130}$ The Craftsman, Apri1, 1910, pp. 67-69.

13IThe Craftsman, April, 1909, pp. ix-x; May, 1909, p. $x$; July, 1909, pp. 464-467. p. 720 .

132 The Craftsman, June, 1905, P. 392; March, I909,

133 See The Craftsman, Apri1, 1913, p. 93. 


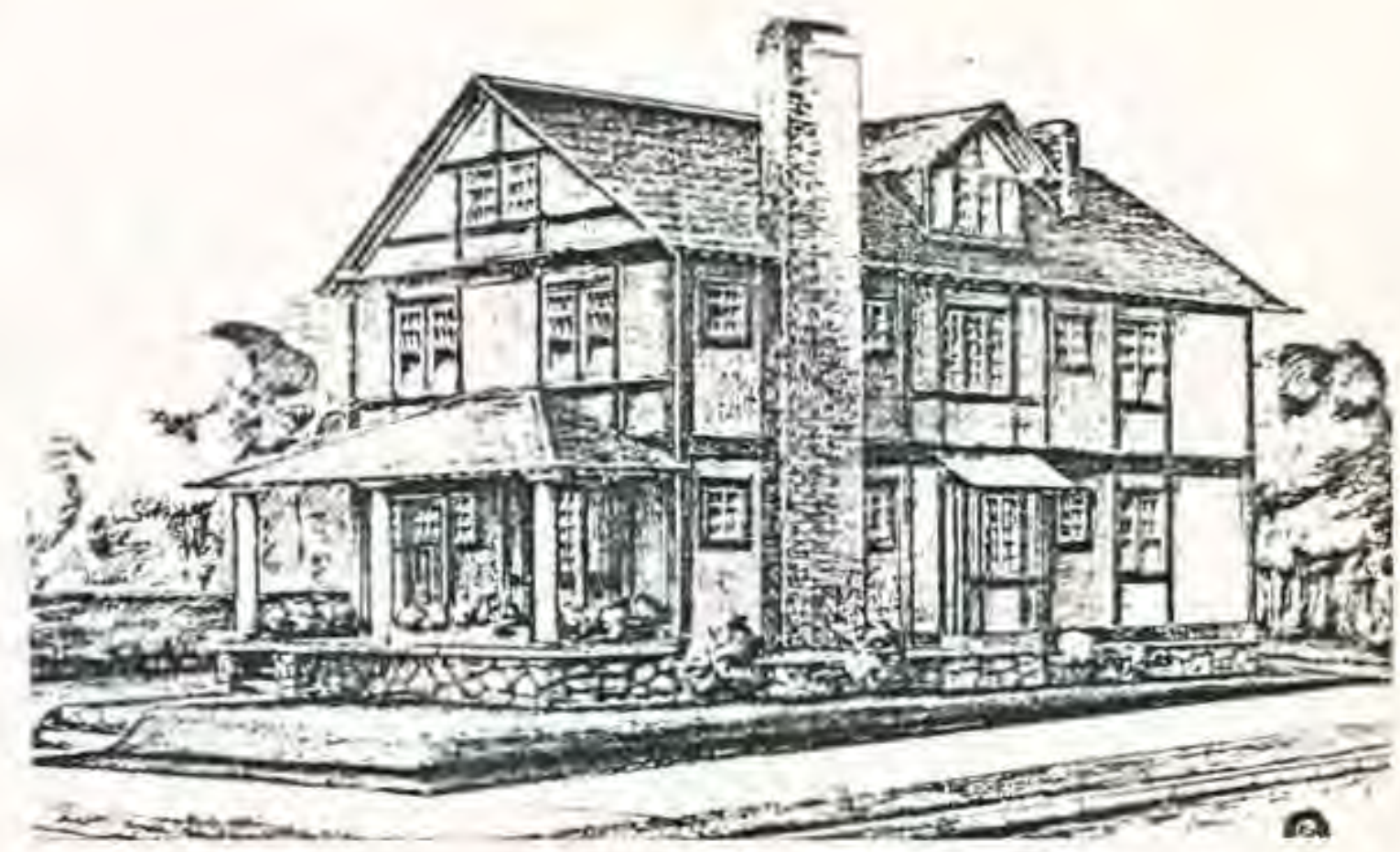

Figure 10. A typical Craftsman house of half timber design two-storied and stuccoed, from The Craftsman. Dccober, 1907, P. I05.

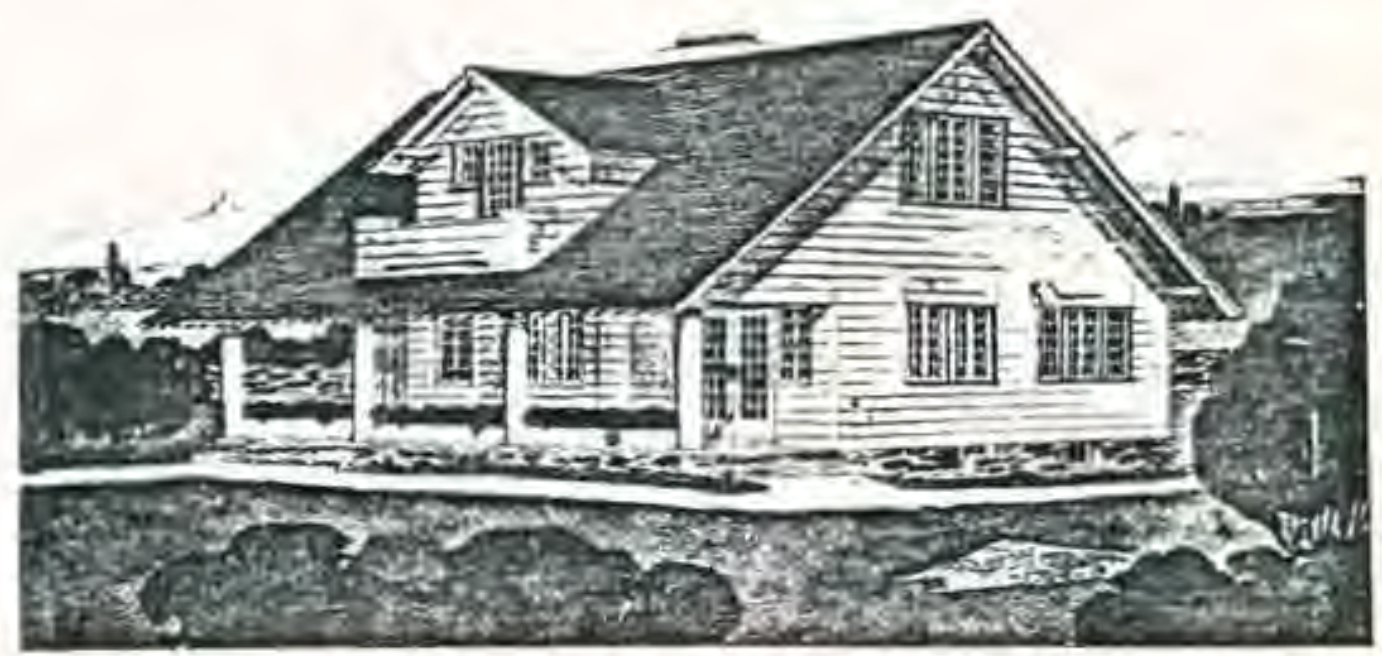

Figure 11. From The Craftsman, March, 1909, p. 720. 
homes built along Craftsman Iines were erected from Alaska to the Figi Islands (yet circulation was only 20,000), 134

One of the greatest differences between the English Arts and Crafts Movement and its American councerpart was that Morris' followers had wanted to return to the handcrafted and American craftsmen learned to utilize the machine. 135 Frank Lloyd Wright had been an early member of the Chicago Arts and Crafts Society and communicated regularly with the English Arts and Crafts exponents. 136 Yet Wright valued the machine; he believed that the simplicity espoused by Arts and Crafts advocates was precisely what the machine could produce, 137 Stickley concurred; in a 1906 Craftsman article, he argued that opposition to machine-work was superficial; that the very invention of the machine was in the spirit of craftsmanship; and that only machine-craft could fill the needs of production in America. 138 production through machine-craft is exactly what made universal popularization of the bungalow possible. A company which began selling ready-cut bungalows in 1904 boasted in their 1919 catalogue that, "modern power-driven

134 Sanders, p. xiv.

$135_{\text {Brooks, p. } 20 .}$

136 Ibid., p. 17.

137 Ibid., p. 19.

${ }^{138}$ The Craftsman, November, 1906, pp. 203-207. 
machines can do better work at a lower cost than hand labor. Then every bit of work that can be done by machine should be done so." 139

One of the Arts and Crafts Movement's most notable contributions to bungalow design was the furniture style which was to become ubiquitous in bungalow decor. Mission furniture was sturdy and straight-lined, usually oaken, and designed in the belief that form should follow function. (See Figure 12.) Though the term mission was assumed to have derived from early California structures, Stickley printed a little story about its true origins in 1909. He wrote that a line of crude, bulky chairs had been marketed at about the same time that the California missions were being rediscovered and that a California dealer had bought the chairs and claimed that they had been found in a mission. Subsequently, other manufacturers capitalized on the deception and an entire line of the furniture was marketed. 140 Whatever the origins of the name, Stickley's mission furnishings were finely crafted of choice materials. Their popular appeal was such that imitators in legion entered the market place between 1905 and 1915. From 1906 until 1915 the Ladies' Home Journal carried the advertisements of numerous companies selling mission or Arts and Crafts furniture: some of it was disassembled and unfinished, shipped

$$
\begin{aligned}
& { }^{139} \text { Aladdin Homes, p. } 3 . \\
& 140 \text { The Craftsman, May, 1909, p. } 225 .
\end{aligned}
$$




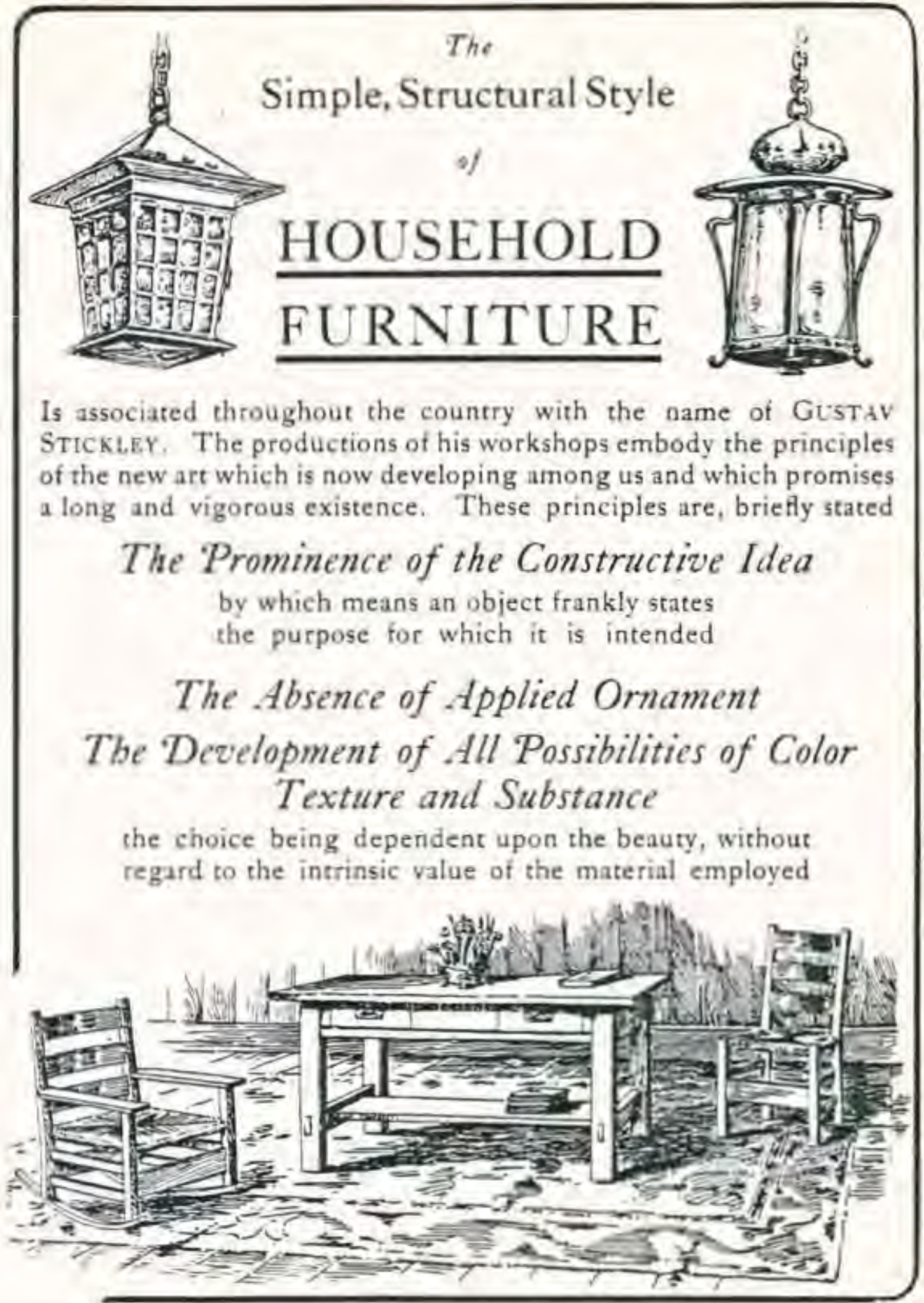

Figure 12. Craftsman furniture advertisement from The Craftsman, May, 1903, p. 160. 
to the buyer in components. 141 Sears, Roebuck and Company began showing chunky, oaken, leather-upholstered furniture, obviously inspired by Stickley in 1908, 142 The Popular Mechanics Company published three volumes on how to make mission furniture in 1909, 1910, and 1912, and Fred T. Hodgson's 1910 Practical Cabinet Maker included instructions for building mission furniture. ${ }^{143}$ Even plans for dolls' houses pictured miniature mission furniture and library globe stands and pianos were designed in the mission style, 144 Although its popularity appeared to be nearly universal, not everyone found mission furniture attractive. One writer For the Ladies' Home Journal thought it too bulky for homes and called it a crude, twentieth-century fad.145 Hodgson wrote that it was unartistic. 146

Karen Current has called Stickley's craftsman movement small and peripheral, but ample evidence that it permeated

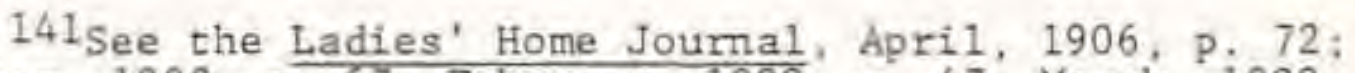
December, 1908 , p. 67; February, 1909, p. 47; March, 1909. P. 84; March, 1914, p. 56; April, 1915, p. 98.

142 Schroeder, Sears, Roebuck and Company 1908 Catalogue, p. 376 .

143popular Mechanics Company, Mission Furniture: How to Make It, 3 vols. (Chicago: Popular Mechanics Company, 1909, 1910, 1912); Fred T, Hodgson, The Practical Cabinet Maker (Chicago: Frederick J. Drake and Company, 1910), p. 187.

144Ladies' Home Journal, December, 1913, p. 48, The Craftsman, October, 1906, p, ii; June, 1909, p. xxvili

145 Ladies' Home Journal, October 1, 1910, p. 85.

146Hodgs on, The Practical Cabinet Maker, p. 187. 
American middle-class society can be found in contemporary popular journals. 147 For a time, Edward Bok included a William Morris quotation on the editorial page of the Ladies' Home Journal and Arts and Crafts designs were often featured in the needlework department. 148 Even fashion showed Arts and Crafts influence; dresses became simpler and looserfitting. Ornament was often derived from geometric or Indian designs. 149

The effects of the Arts and Crafts Movement were obvious, but bungalow design has often been attributed, at least in part, to other foreign influences. as well. The origins in India have already been examined. Stickley wrote that long, low lines and provision for outdoor living by way of verandahs came from Spanish mission architecture, and Esther McCoy saw Spanish influence in the work of the Brothers Greene, 150 Clay Lancaster raised the possibility of French Colonial influence by comparing the bungalow's roofline and porch to the hipped parasol roofs and galleries of those post-supported structures built along the Mississippi, 151 Lynes traced the wide overhanging eaves to

147 Current and Current, p. 4.

148 See the Ladies' Home Journal, January, 1907 through July, 1907, editorial pages; December, 1908, p. 366.

149 Ladies' Home Joumal, September, 1913, pp, 26, 37. 38, 74 ; November, 1913, Pp. $41-42$.

${ }^{150}$ The Craftsman, February, 1908, p. 568, McCoy, p. 108.

151Lancaster, Art Bulletin, p. 241. 
the Swiss Chalet, 152 Perhaps greatest attention has been paid the similarities between the bungalow and Japanese architecture. Clay Lancaster's The Japanese Influence in America examines the possibilities of such a connection in depth.

In searching for influences which had direct bearing on the development of the bungalow, one must conclude that the reasons for its great popularity were many. Cultural values and social conditions were changing. American society was experiencing technological progress at an unheard-of pace. At the same time, the Arts and Crafts Movement promoted simplicity and honesty, and new ideas were germinating in the field of architecture. The marketing techniques and fndustrial capabilities of enterprising building firms helped them capitalize on these ideas. Utilizing the essentials of various cultural design notions and juggling them into a uniquely American architectural vocabulary, builders and architects evolved a domestic style appropriate to the needs of middle America. That a new mode of building evolved, found popular appeal, and proliferated under these circumstances is not surprising.

152 Lynes, p. 188. 
CHAPTER IV

THE BUNGALOW AGE IN MCMINNVILLE, OREGON

MeMinnville, Oregon, small city thirty-five miles southwest of Oregon's largest urban center, experienced slow but steady growth between 1900 and 1920. Among the dwellings built there between 1909 and 1922, a large proportion were designed in the bungalow style. McMinnville was not a true microcosm of the national picture, for it was rural, slow to grow, and its population was relatively homogeneous. It can provide a study of the influences bearing upon the immense popularity of the bungalow style during this period, however, because the population was heavily middle-class and because the bungalow style did proliferate there. This chapter will examine McMinnville's economic, political, and social climate during the period under study and attempt to determine what specific factors led to the construction of such a large percentage of bungalows during the first two decades of the twentieth century.

$$
\begin{gathered}
\text { MCMINNVILLE, } 1909 \text { - } 1922 \text { : ECONOMICS, } \\
\text { POLITICS, AND GROWTH }
\end{gathered}
$$

McMinnville lies in a fertile stretch of prairie on the winding Yamhil1 River in northwestern Oregon. Its original eighteen-block site was platted in 1856 on a portion 
of the donation land claim belonging to Tennessee pioneer, William T. Newby. 1 Newby established a flouring mill to serve the area's growing number of settlers and soon after the town plat was drawn, a college was founded.2 In 1876 Mclinnville was incorporated and three years later the railroad connected the town with eastern trade centers. ${ }^{3}$ Yamhill County's seat of government was moved from Lafayette to McMinnville in 1888, and in 1889, McMinnville became the first town in Oregon to establish a municipally-owned water and 1 ight facility, 4 The Yamhill River was rendered navigable with the construction of locks at Lafayette in 1900.5 These were the major milestones in the town's progress until it had reached a population of 1,420 by the turn of the twentieth century. Between 1900 and 1920, it nearly doubled in size to a population of $2,767.6$ Compared to the entire state's population growth from 413,526 in 1900 to 783,389 in 1920

IYamhill County, "Deed Book G," McMinnville, Oregon, p. 334; Daily Reporter, January 10, 1887, p. 2.

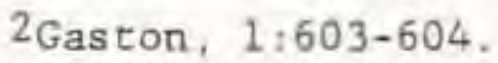

${ }^{3}$ City of McMinnville, "Record Book No. I," McMinnville, 1876, P. I; Yamhili County Reporter, April 25, 1879, p. 1 .

4Yamhi11 County, "County Commissioners' Journal," 25 vols.. Lafayette/McMinnvilie, Oregon, 1856-1941, 9:380381, McMinnville City Council, "Minute Book 7," August 20, 1889 , p. 49; August 22, 1889, p. 51.

5 The Telephone Register, August 30, 1900, p. 3: September 27,1900, p. 3 .

6 United States Bureau of Census, Census of the Population: 1970, vol. 1, Characteristics of the Population: Part 39. Oregon (Washington, D. C., linited States Government Printing Office, 1973), Table 7. 
(an 89 percent 1ncrease), this rate of expansion was not surprising, 7 Between 1912 and 1928, however, as redrawings of Sanborn maps show, growth was certalnily not rapid. Figure 13 portrays partial Sanborn renditions of two representative residential neighborhoods which grew very modestly during those years. 8

McMinnville was largely a farming community at the turn of the century and remained so throughout the bungalow period. In 1905 the McMinnville Telephone Register reported that most of the farms near McMinnville were grain-producing tracts of from five to twenty acres. ${ }^{9}$ Livestock raising justified the formation of a county livestock association in 1905.10 The need for processing industries to render the local agricultural products marketable prompted a continuous newspaper campaign to encourage investment in canneries, fruit driers, and creameries throughout the first decades of the century, 11 The agricultural economic base began to shift toward fruit and nuts in 1908 and during the next few years, numerous tracts were subdivided for tree planting and people

7Norma Paulus, comp, , Oregon Blue Book, (Salem, Oregon: Daily Journal of Commerce for the State Printing Department, 1979), p. 352 .

${ }^{8}$ Sanborn Map Company, "McMinnville, Yamhili County, Oregon," MAPS (New York; Sanborn Map Company, 1912), PP. 3. 5; 1928 , pp. 6, 9.

${ }^{9}$ The Telephone Register, May 6, 1905, p, 4.

10 The Telephone Register, January 21, 1905, P. I.

$11_{\text {See }}$ The Telephone Register, August 19, 1905, p. 4. 


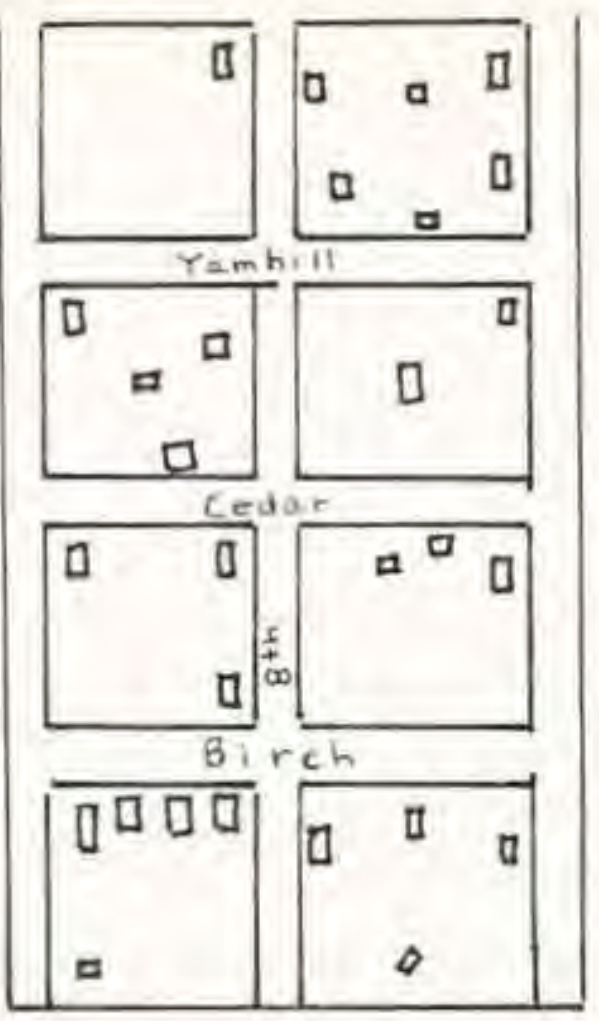

1912

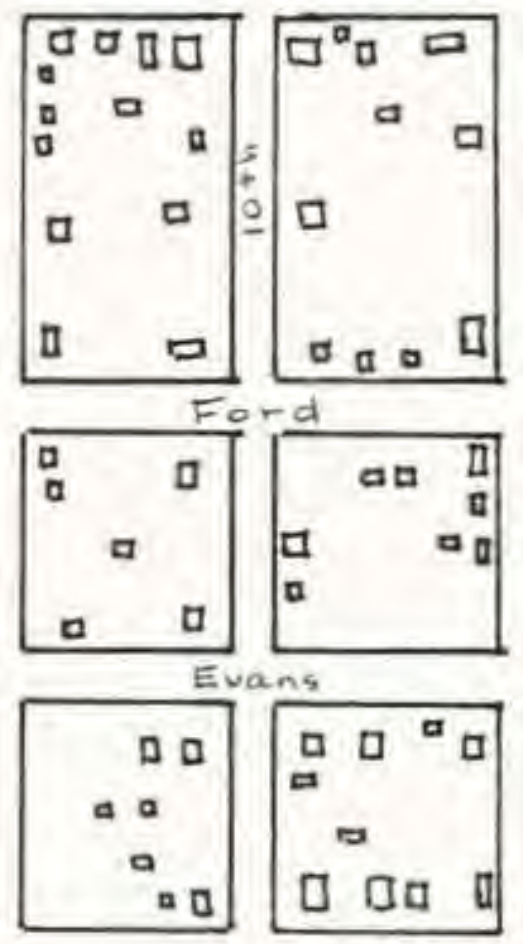

1912

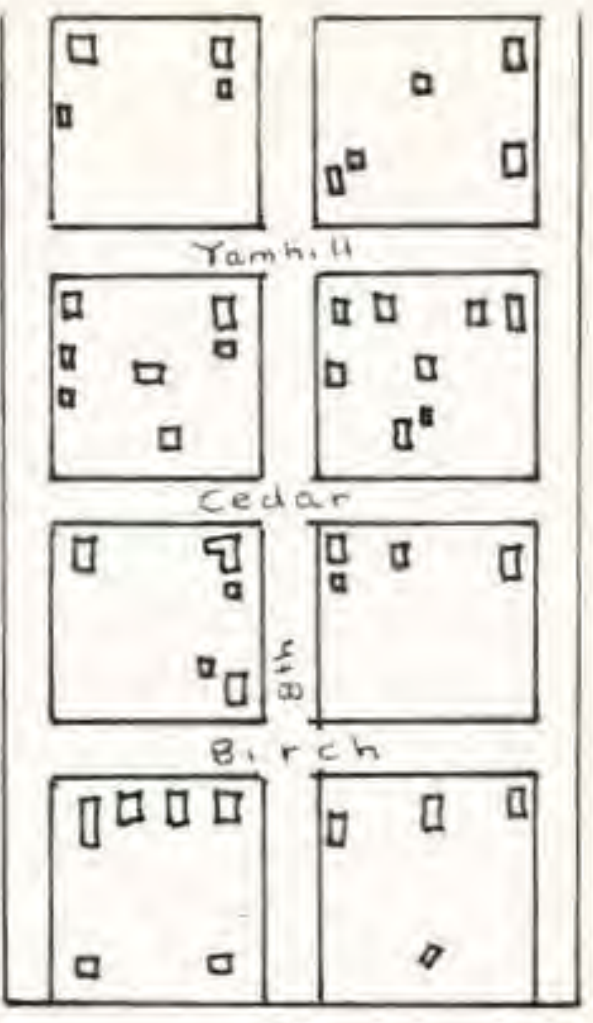

1928

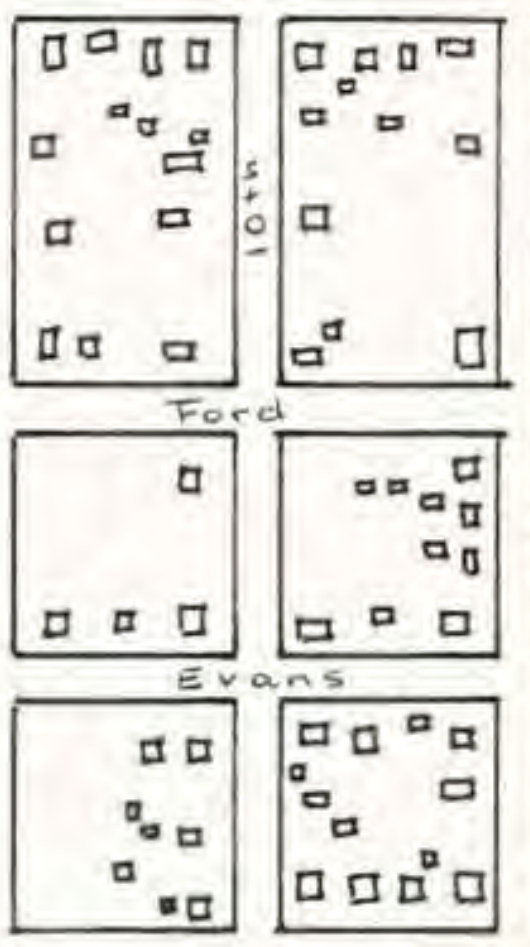

1928

Figure 13. The buildings in two representative neighborhoods in McMinnville in 1912 (on the left) and 1928 (on the right). 
were encouraged to invest in orchards, Cherries, filberts, apples, and walnuts were planted and in February of 1910. talk of forming a fruit growers' association was reported, 12 Grain and hops continued to be important crops well into the 1920 's. A promotional booklet printed in the late 1920's pointed out that Yamhill County was diversified in its agriculture; dafrying, crops, and orchards were all important enterprises. The county's major industries, the booklet reported, were grain and timber. 13

The 1912 Polk's Yamhill and Washington Counties Directory reveals that McMinnville at that time had one sash and door factory, two flouring mills, a brick factory, two creameries, and a condensed milk plant, 14 The Willamette Valley Condensed Milk Company, reportedly the largest such plant on the coast, was established in McMinnville in 1908 and was expected to employ a large payroll of $\$ 100,000.15$ By the 1920's, two canneries had been established in McMinnville, 16 These few industries furnished but little

${ }^{12}$ See The Telephone Register, March 13, 1908, P. 6; April 8, 1910, p. 1; February 18, 1910, p. 8.

I3McMinnville Chamber of Commerce, Yamill County Oregon: One of the Highly Favored Sections of the Pacific बorthwest (McMinnville, Oregon: The Telephone Register for the Chamber of Commerce, n, d,), Pp, 11-13.

14Polk's Yamhill and Washington Counties Directory, 2 vols. (Portland: R. L. Polk and Company, 1912-1913). $2: 79,85,92,93,106,112$.

${ }^{15}$ The Telephone Register, May 15, 1908, p. 4.

16 Chamber of Commerce, Yamhill County Oregon. p. 7. 
employment for laborers and farming continued to be the economic base. The Chamber of Commerce warned in the 1920's that

we cannot conscientiously recommend to the poor man. destitute of resources to establish himself,... . to make the long trip West... If he is dependent upon day labor, 17

McMinnville's lack of economic diversity fostered homogeneity in its population.

The only local political issues which hinted of reform in McMinnville during the early years of the century were a successful effort to oust two councilmen in 1900 and a recurring challenge to institute a new charter beginning in 1902. 18 A 1905 newspaper article alluded to a Good Government League, but the press made no further mention of it, 19 Support for reform on the state and national levels was evident at least in McMinnville's press. A 1905 Telephone Register editorial railed against the Capitalists who had monopolized the falls at Oregon City and called for all unappropriated water power to be ceded to the State. That same year the paper hailed the election of Mayor Harry Lane

17 Ib1d., p. 30.

18The Telephone Register, March 8, 1900, p. 3; April 26, 1900, P. 3; McMinnville City Council, "Minute Book 6," MeMinnvilie, Oregon, 1902, PP. 135, 140, "Minute Book 7," 1907, pp, 125, 141.

19 The Telephone Register, April 22, 1905, p. 5. 
in Portland as an end to fraud and corruption in that city. and urged strict federal control over railroads, 20

The local Socialist Party was, according to one source, "considered serious by some, amusing by most."21 In 1902 the press could be counted among the amused; a Telephone Register report of a Socialist gathering called it "not large nor enthusiastic," and claimed that the speaker had convinced any who might be leaning toward that party that they were not Socialists. 22 The state Socialist convention was held in McMinnville in 1908, but in 1912, the newspaper could find only fifty members in the local party, 23 In 1912. Wisconsin reform leader and Progressive candidate for president, Robert LaFollette, received a warm welcome in McMinnville and finished a very creditable third behind Taft and Roosevelt in the county's primary election tally that year. 24 But the county was overwhelmingly conservative, and an analysis of party registration in 1912 revealed that out of a total of 3,301 voters, 2,075 or 63 percent, were Republicans, 807 were Democrats, and both the Prohibition and Socialist

20The Telephone Register, May 13, 1905, p. 4; June 10, 1905, p. 1; May 20, 1905, P. 4:

21Floyd Ode11, interview at McMinnville, Oregon, January 23, 1981.

22 The Telephone Register, February 20, 1902, p. 3.

23 The Telephone Register, March 13, 1908, p. 6; February 9,1912, P. 5 .

24The Telephone Register. April 9, 1912, p. 1; April 26. 1912, p. T. 
Parties claimed less than 200 each. 25 That a certain amount of political apathy exisced was evident in a 1908 City Council meeting report which showed that in the May election of that, year, only fifteen percent of the city's electorate had exercised their franchise, "towit, 54 legal voters."26

Social reform may have commanded more attention. The local press secretary of the W. C. T. U. wrote an article for the Telephone Register in 1907 in which she exposed the cruelties of child labor. Another article by the same author enumerated W. C. T. U. positions for equal moral codes for men and women, equal wages, and half days off on Saturdays for all workers. 27

At the turn of the century the town was beginning to make the important decisions which would enhance the convenlence with which people carried on their daily lives and chroughout the bungalow period, these improvements continued apace. David Handin suggests that special interest groups dictated or blocked improvements in many towns, but during the period from 1900 to 1920 in McMinnville, a time of bustling improvements in both services and physical development, one finds little evidence of this, 28

${ }^{25}$ The Telephone Register, April 12, 1912, p, 6. 26McMinnville City Council, "Minute Book 7." May, 1908, p. 250 .

27 The Telephone Register, April 19, 1907, p. 8; April 26, 1907, p. 5. 28 Handin, p. 114. 
The first contract let by the city for garbage collection was signed in October of 1906.29 Mail delivery followed two years later. 30 The first sewer line, according to City Council minutes, was laid in 1900 and from that year throughout the next two decades, much of the council's business consisted of expanding and refining a sewer system. 31 By 1904 an ordinance to regulate the plumbing of the lines connected to the city system was enacted and that same year the rapid increase in sewer construction necessitated the hiring of extra help in the city recorder's office. 32 All privies within sewer districts were required to connect with sewer lines by an ordinance passed in 1908,33 Thus the way was paved for the bungalow to make indoor plumbing universal in McMinnville.

Cement sidewalks began replacing McMinnville's oftrepaired boardwalks as the bungalow style was beginning to gain popularity. A full-length cement sidewalk was built for the main business artery, Third Street, in 1907 and the only recorded resistance was a note in the council minutes

29McMinnville City Council, "Minute Book 7," October 2, 1906 , p. 51.

$$
{ }^{30} \text { Ibid. . July 7, 1908, p. } 280 .
$$

31McMinnville City Council, "Minute Book 6," July 7, 1900, p. 46.

32Ibid.. May 3, 1904, p. 338: September 16, 1904. P. 420 .

33McMinnville City Council, "Minute Book 7," December 1, 1908, p. 324. 
that one prominent businessman had to be "forced. . to build said walk on proper grade,"34 Plank sidewalks were still being used in outlying neighborhoods, and the number of new ones being laid in 1908 indicates that residential areas were being improved rapidly. Crosswalks over the unpaved streets were making the neighborhoods easier to navigate on foot, 35

The extension of transportation arteries during these early years was another indication that the town was preparing for growth in the residential areas. In the fall of 1903 alone, the City Council passed ordinances providing for four street extensions and there were many similar ordinances passed throughout the next few years.36 The Council minutes during this period reveal that most of the city's business involved enacting improvement measures; correcting street grade, replacing walks, erecting street signs, organizing a numbering system, and installing drain tiles. 37 The most dramatic street improvement to grace a rain-drenched

34 Ibid.. April 11, 1907, p, 113; July 2, 1907, p. 143. 35 Ibid., April through September, 1908, pp. 239-241, $271-273,294-305$.

36McMinnville City Council, "Minute Book 6," September 1, 1903, p. 245; October 6, 1903, p. 256: March 1, 1904, p. 297; "Minute Book 7." Apri1' 23, 1906, P. 24; March 3, 1908, P. 227; March 18, 1908, p. 233.

37Ibid. . May 9, 1907, pp. 116-122; June 4, 1907. pp. 127- $\sqrt{28}$; February 4, 1908, P. 220; March 31, 1908, p. 237: June 9, 1908, p. 273; June 16, 1908, pp. 275-278; JanuaryFebruary, 1909, pp. 350-358. 
Oregon town in the early 1900's was, of course, paved streets. and in 1911. McMinnville let a contract to Warren Construction Company of Portland to pave sixty-two blocks of street for $\$ 120,000,38$ A 1920 's Chamber of Commerce booklet could elaim that, by that time, the city had twelve miles of paved streets, 39

That McMinnville had enjoyed the benefits of its own water and light facility as early as 1889 has already been noted. By 1899 , the city's streets were illuminated by arc lights. 40 The town had grown sufficiently by 1904 that the original waterworks on the Yamhill River could no longer supply the demand and that year the city's electorate agreed to issue bonds to build a new plant and to appropriate the water flow from Baker Creek, the same stream northwest of the town whose waters had supplied William T. Newby's gristmi11. 41 The following year, a Water Commission was appointed and after two years of legal maneuvering which included a vote of the people to amend the city's charter, control of the water and light plant was tumed over to this body. 42

${ }^{38}$ The Telephone Register, July 14, 1911, p. 1.

39 Chamber of Commerce, Yamhil1 County Oregon. p. 6.

${ }^{40}$ The Telephone Register, November 2, 1899, p. 3.

${ }^{41}$ See McMinnville City Council, "Minute Book 6 ," September 8, 1903, p. 248; October 6, 1903, pp. 253-254; September 13, 1904, P. 414; September 16, 1904, p. 418,

42 Ibid, February 5, 1905, p. 475; April 10, 1905 , p. 511. "Minute Book 7," October 2, 1906, pp. 53-54; December 3, 1906, p. 69; December 7, 1906, p. 72; December 20, 1906, p. 76; September 3, 1907, pp. 178-190. 
By the 1920 's, McMinnville had again outgrown its water supply and a fourteen-acre reservoir on Haskins Creek in the Coast Range was completed for the city's use in 1928.43

Edith Allen wrote that by 1907 there were 1, 467,000 telephones in the United States. By 1920 that figure had more than doubled to $3,156,000,44$ McMinnville had eight subscribers to its telephone system in 1900; by 1906 there were sixty-five; and in 1928, the Chamber of Commerce reported that there were 980 subscribers within McMinnville's city limits. 45 The City Council had granted a ten-year franchise for telephone service within McMinnville to the Mutual Telephone Company in 1902.46 This company had connected nearly all the small communities in Yamill County by 1905.47 But by 1908 there was a need for Iong distance service and a group of prominent local businessmen organized the Long Distance Telephone Company which would absorb Mutual and provide statewide long distance service. 48 According to the local press, this group did not pay the city for the franchise they were granted and there were

${ }^{43}$ Chamber of Commerce, Yamhi11 County Oregon, p. 25. 44 Allen, P. 120 .

45 Yamh111 County Reporter, March 9, 1900, p. 5; Telephone Register, February 10, 1906, P. 6; Chamber of Commerce, Yamhill County Oregon, pp. 6, 26.

46 McMinnville City Council, "Minute Book 6 ," August 5. 1902, p. 161.

${ }^{47}$ The Telephone Register, January 21, 1905, p. 6. ${ }^{48}$ The Telephone Register, June 12,1908, p. 6. 
complaints from at least some of the citizens. The Telephone Register, taking the part of the company, pointed out that the stockholders had, free of charge, installed a fire alarm system which was to work through the telephones. This, the newspaper told the skeptics, was not only fair, but also good for the city. 49 This episode was the only hint of franchise abuse evident in public records during those years in McMinnville, and perhaps it was, as the newspaper claimed, perfectly equitable. In any case, the scant attention it received indicates that McMinnville was not on the alert for corruption.

As the city grew, building regulation became necessary and the first building ordinance, passed in 1904, provided that buildings within the city which had projections over walks were required to install eaves troughs and spouts for draining water. 50 In 1909 a number of building restrictions were 1mposed. One allowed only brick, stone, or concrete construction within the city's fire limits; another restricted the repair of wooden buildings within the same area; and another established an electrical wiring code within the city. 51 That year the city enacted an ordinance which

${ }^{49}$ The Telephone Register. August 7. 1908, p. 1.

50McMinnville City Council, "Minute Book 6," April 5, 1904 , p. 325.

51McMinnville City Council, "Minute Book 7," January 20, 1909, p. 346; May 4, 1909, p. 399. 
required a buflding permit for any construction, major repair, or alteration within the corporate city limits. 52

By 1912 McMinnville's public school system included two elementary schools, a new high school, and within the next two years, the state's first junior high school.53 The Board of Education had expanded high school curriculum to include eleventh grade in 1908 and in 1911, the county school superintendent could boast that the schools were on a better footing than ever before. 54 The Catholic Church maintained a preparatory academy in McMinnville, and since its very beginnings, the town had enjoyed the benefits of a college. Townspeople demonstrated their regard for the college's contribution in 1907 when businessmen raised $\$ 12,625$ in concributions to avert financial disaster facing the institution. 55

After several years of renting rooms in a commercial building for library purposes, the citizens of McMinnville obtained a pledge from Andrew Carnegie for a $\$ 10,000$ structure in 1912, and a substantial library was erected that year. 56 Two newspapers, The Telephone Register and The News

52 McYinnville City Council, Ordinance 618, "Ordinance Book 6," (1909), pp. 81-84.

53Polk's Yamhill and Washington Counties Directory. $2=58$; Chamber of Commerce, Yaminill Councy Oregon, P. 28.

54 The Telephone Register, January 27, 1911, p. 1.

55 The Telephone Register, April 26, 1907, p. 1 ,

56 The Telephone Register, May 17, 1912, p. 1. 
Reporter, served the communtty during the bungalow era. With the implementation of physical improvements and the establishment of cultural and educational institutions, McMinnvilie had defined itself as a community which provided an environment conducive to the ideal middle-class family life. The bungalow symbolized the achievement of that ideal.

Robert Dykstra wrote that most American small towns would be cities if they could, and McMinnville was no exception.57 The years during which the bungalow style flourished were years of boosterism. The need for processing industries and the desire for more settlers and more businesses resulted in promotion aimed at attracting immigration which was to continue throughout the twentieth century. The local newspapers from 1900 into the $1920^{\prime}$ s reflect an urgent desire to promote the town's virtues and to attract investors and industry. A variety of organizations for the purpose of accomplishing these goals emerged. Nineteen hundred and eight was a year of particularly zealous boosterism in McMinnville. In March of that year, a town meeting was called while businesses closed for two hours so that items of interest could be discussed. "Every patriotic citizen . . should attend," wrote the editor of the Telephone Register. The meeting garnered $\$ 3,500$ worth of pledges to defray costs of advertising the county. The newspaper

57 Robert Dykstra, The Cattle Towns (New York: Alfred A. Knopf, 1968), P. 3 . 
continued the campaign the next month with an article headlined; "Every Citizen Should Boost."58 Later that spring a mass meeting of McMinnville's women formed inspection committees whose purpose was to tidy up the city in preparation for the "large immigration to this county during the coming season." 59 In 1903 the Board of Trade spent $\$ 989$ printing a pamphlet which advertised the comminity's attractions, 60 The Commercial Club sent 5,000 promotional booklets and 12,000 folding postcards extolling Yamhill County's virtues to cities throughout the Midwest in 1910.61 The boosterism continued into the 1920's; in 1921 the Commercial Club encouraged property owners to build houses on their empty lots so that homes would be available to newcomers. 62 Another promotional booklet was printed that same year. 63 Real estate was advertised to attract investors and real estate agents joined the boosterism campaign with fervor. A 1907 newspaper revealed a large two-column advertisement attesting to McMinnvilie's attractions and paid for by a real

58 The Telephone Register, March 20, 1908, p. 5: March 27, 1908, p. 1; Apri1 10, 1908, p. 4.

${ }^{59}$ The Telephone Register, April 24, 1908, p. 8.

60 McMinnville Board of Trade, "Minute Book," McMinnville, Oregon, February 4, 1903.

61 The Telephone Register, March 4, 1910, p. 1.

62 The News Reporter, February 17, 1921, P. 1.

63 The News Reporter, September 15, 1921, p. 1. 
estate firm. 64 Prominent businessmen formed the Yamhil1 Development and Improvement Company in 1911 and advertised the McMinnville Plan, a scheme to acquire land, subdivide it, and plant orchards. 65

Robert Wiebe has asserted that the community crisis of the early 1900's resulted in elass consciousness. 66 Twentythree interviewees who lived in McMinnville during the bungalow years denied that any real sense of class distinction prevailed. Most acknowledged, though, that there were social groups and that these groups were based upon different common denominators. Social nuclei were often churches or organizations such as the Masons, Elks, or Knights of Pythias. Several of the interviewees revealed that close groups of friends shared similar economic status but nearly all the people who contributed data could be placed on the middle class spectrum, 67 Even those who considered themselves poor maintained that they were not aware of clear class distinction, 68 There were, nevertheless, very poor people who could

64 The News Reporter. May 23, 1907, p. 2.

65 The Telephone Register, June 16, 1911, P. I.

66wiebe, pp. 111-113.

67 Evelyn Gibson DeGordin, interview, McMinnville, Oregon, January 14, 1981; Mina Redmond, interview, MeMinnville, Oregon, February 23, 1981: Edna Hodson Stanard, interview, McMinnvilie, Oregon, February 3, 1981.

68 Interviews with Floyd Odel1; Arleta Loop Shotwel1. MeMinnvilie, Oregon, March 3, 1981. 
not care for themselves Iiving In MoMinnville. There were poor in sufficient numbers to warrant the establishment of a county poor farm in 1903,69 The daughter of the farm's superintendent in the $1920^{\prime} \mathrm{s}$ recalled that the facility sheltered approximately thirty people. 70

Most of the city's populace were middle-class and their social activities conformed to middle-class values. There were movies, dances, and theater in McMinnville, but the home provided much of the entertainment. One woman whose father had immigrated to Oregon from Tennessee remembered that many relatives came to their home when she was a youngster from 1906 to 1920; her parents' social lffe consisted largely of entertaining family. Others remembered large dinner and card parties in their parents' homes during those years, and one woman recalled her foster mother reading aloud from Dickens each evening. 71 Home encertainment was more structured in the early part of the century than it is now and well into the 1930's, at least one group in McMinnville observed the custom of calling on friends only during certain at-home times and of leaving calling cards, 72 This tendency to socialize within the home created needs which had to be met

${ }^{69}$ Gaston, 2:898.

$70 \mathrm{Alice}$ McCune Holland, telephone interview, February 1, 1981.

71 Interviews with Arleta Loop Shotwel1; Dorothy Wortman Gunness, McMinnville, Oregon, Feburary 24, 1981; Willetta Leever Dow.

72 Interview with Dorothy Wortman Gunness. 
by the house, Its plan, and its accoutrements. The new bungalow style met those needs.

The bungalow also allowed McMinnville women to spend time away from home. Between 1907 and 1911, over thirty social, fraternal, and promotional organizations, excluding church affiliations, were mentioned in the local press--over thirty organizations in a population of 2,000.73 Many were purely social, but there was evidence of a mild spirit of reform in some of them. Three which aimed at intellectual advancement for women were the Shakespeare Club, the Current Events Club, and the Self-Improvement Club. These three groups cooperated to furnish rooms for a local branch of the Young Mens' Christian Association in 1908.74

Civic Improvement was mentioned earlier as an area of reform common to most small communities in the early 1900's and MeMinnville was no exception. In 1908 a group of townswomen formed the Civic Improvement Club, with the express purpose of city beautification. 75 Their activities included petitioning the City Council to pass ordinances addressing street cleanliness, raising money to erect a bandstand, and campaigning for a library.76. In 1906 a group of public-

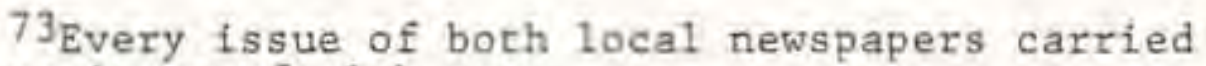
numerous items of club news.

74 The Telephone Register, February 21, 1908, p. 4.

${ }^{75}$ The Telephone Register, May 22, 1908, p. 6 .

76McMinnville City Council, "Minute Book 7," June 9. 1908, p. 272, April 6, 1909, Pp. 396-397; The Telephone Register, March 8, 1912, p, I. 
spirited businessmen including merchants, bankers, and attorneys, submitted to the City Council a proposal for establishing a city park. The plan was adopted and in 1908 . the city authorized bonds to lay out and landscape a park on the site of William T. Newby's original mil1.77

Prohibition was a reform measure widely embraced in Yamhill County particularly by women. The strong local W. C. T. U. chapter campaigned vigorously for county-wide prohibition as early as 1904. The measure was passed in an election that year and after testing in the court, prohibition went into effect in Yamhill County in 1906,78 The question arose again in 1908 and items in the local press indicated that there was strong feeling on the subject. Prohibition was overwhelmingly retained at the pol1s, 79 Although the penalty for selling liquor in Yamhill County after prohibition passed could be as high as $\$ 150$ and ten days in jail, the evidence leaves no doubt that people in McMinnville continued to drink. 80 All of the long-time

77McMinnville City Council, "Minute Book 7." Detober 2, 1906, pp. 56-57; Apri1 7, 1908, P. 238; June 9, 1908, P. 274.

78 The Telephone Register, April 8, 1905, p. 1; May 13. 1905. p. I, October 28, 1905, p. 4; McMinnvilie City Council, Ordinance 416, "Ordinance Book 5," p. 85 .

79 The Telephone Register, May 1, 1908, p. 4; May 22, 1908, p. 3; May 15, 1908, p. 7; June 12, 1908, p. 3, ${ }^{80}$ The Telephone Register, August 6, 1909, P. 6. 
residents interviewed recalled that there had been drinking during those years, much of it in the homes of prominent cirizens. The newspapers carried stories about drunks on the streets and several people interviewed remembered a few habitual drinkers who wandered about the town. 81

The reform question which would have had the greatest influence on the home, that of woman's equality, was largely ignored in McMinnville from 1900 to 1920. Most of the interviewees recalled that, as a rule, women stayed home and that few worked. There is evidence that there were women in McMinnville's work force but in accordance with the views of the women's magazines cited earliet, they performed jobs which fell within the feminine sphere. The 1905-1906 Oregon and Washington State Gazatteer lists seven women in McMinnvilie's business community: three milliners, two music teachers, and two dressmakers. The 1911-1912 edition lists eight: one music teacher, four milliners, two dressmakers, and one shoe shop proprietor, 82 These figures do not include domestic help, shop clerks, clerical workers, or public school teachers and advertisements throughout the early 1900 's indicate that women were employed in these areas. ${ }^{83}$

81 The Telephone Register, March 11, 1910, p. 6; April 7, 1911, p. 5; interviews with Zonweiss Rogers Mead, Willetta Leever Dow.

820regon and Washington State Gazatteer, 1905-1906. pp. 283-286; 1911-1912, pp. 215-216.

${ }^{83}$ See The Telephone Register, December 16, 1910, p. 6; June 2, $1911, \mathrm{p}, 6$; February $2,1912, \mathrm{p} .3$ for examples. 
There was a striking absence of consciousness in McMinnville regarding woman suffrage according to the interviewees consulted for this study. Oregon was to grant women the franchise in 1912, a fact which suggests that during the early years of the twentieth century, considerable attention was being given the question. 84 Among the McMinnville residents questioned, a number were women who would have been either reenagers or young wives and mothers during the years just preceding the passage of woman suffrage. Yet not one incerviewee recalled the issue's being discussed. One said she didn't recall being impressed by the suffrage question: another said women thought very little about it. A woman who was 16 in 1912 said she did not believe that women knew what was happening and another who was the young mother of a smaIl child at the time recalled that she was too busy to consider the issue.85 The McMinnville Telephone Register gave the subject only cursory attention. In a 1908 editorial, the newspaper opposed woman suffrage on the grounds that it forced the franchise on a segment of the population which did not want it, 86 By 1912, however, the paper had shifted its position and congratulated the Civic Improvement Club

${ }^{84}$ Paulus, Oregon Blue Book, p. 352.

85 Interviews with Esther DeHaven, Zonweiss Mead. Mina Redmond, Edna Stanard, Lauretta Wheeler.

${ }^{86}$ The Telephone Register, May 29, 1908, P. 6. 
when the group drafted a resolution petitioning the men of Oregon to give women the franchise. 87

THE BUNGALOW STYLE IN MCMINNVILLE, OREGON, $1909-1922$

The bungalow style reigned supreme in McMinnville between 1909 and 1922, the period during which the case studies were built. Although the Sanborn Maps showed relatively little bullding (Figure 13), McMinnville supported a number of builders and several building-related industries. There was only moderate activity in real estate development during these years, but home ownership in McMinnville appears to have surpassed the national average. The new bungalows differed sharply from the styles of homes built in 1900 and 1905, and the sudden shift seemed to stem from several factors: economics and life style to some extent, but above al1, from the fashion set by magazines, periodieals, and popular builders' plan books .

In 1980,790 dwellings were photographed for an historic resource inventory within a 1,84 square mile core of McMinnville's incorporated area. Two hundred eighty-five of these, or 36 percent, exhibited bungalow style influence. 88 There is endless variety among bungalow-style houses, but four types occur most often in McMinnville: 1) the house

87 The Telephone Register, April 12, 1912, p. 4.

88McMinnville Planning Department and Oregon State Historic Preservation Office, "Historic Resource Inventory, Phase I: McMinnville, Oregon," 3 vols.., McMinnville, Oregon, 1980. 
with an extended roof over a full-width porch; 2) the house with a single frontal gable, with or without attached porch; 3) the house with double frontal gables; and 4) the hip roof house. (Figure 14). There are many variations within each of these groups and a large number of bungalow style houses which do not fall into any one of them. These four basic types and many variations can be found in any number of contemporary plan books and magazines. Figure 15 illustrates prototypes.

The bungalow-style home dominated McMinnville's building activity during the period under study. Seven new homes were mentioned in the Telephone Register during 1909; of the five which could be identified, three were bungalowstyle houses. 89 AIl of the houses which could be identified from 1912 were bungalow-style houses, 90

It may be evident in retrospect that building was relatively slow in McMinnville during the first two decades of the century, but the local press found it worthy of enthusiastic reporting. The Yamhil1 County Reporter, precursor of the News Reporter, described a survey conducted in 1899 which found that ten new residences at a total cost of $\$ 12,000$ had been erected in McMinnville and its environs

${ }^{89}$ The Telephone Register, July 16, 1909, p. 6, August 13,1909, p. 5 ; September 3, 1909, p. 6.

90The Telephone Register. February 23, 1912, p, 6; May 10, 1912. P. 5; April 5, 1912, p. 6. 


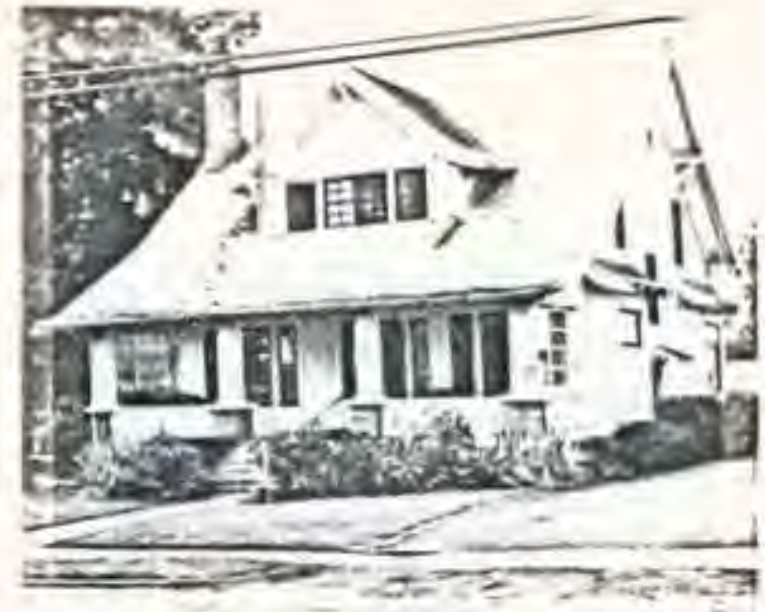

House with sloping roof over porch.

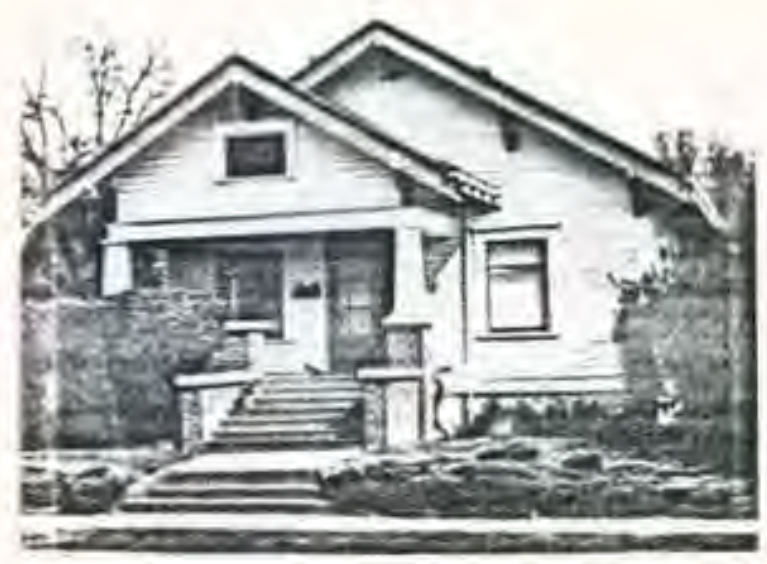

House with double frontal gable.

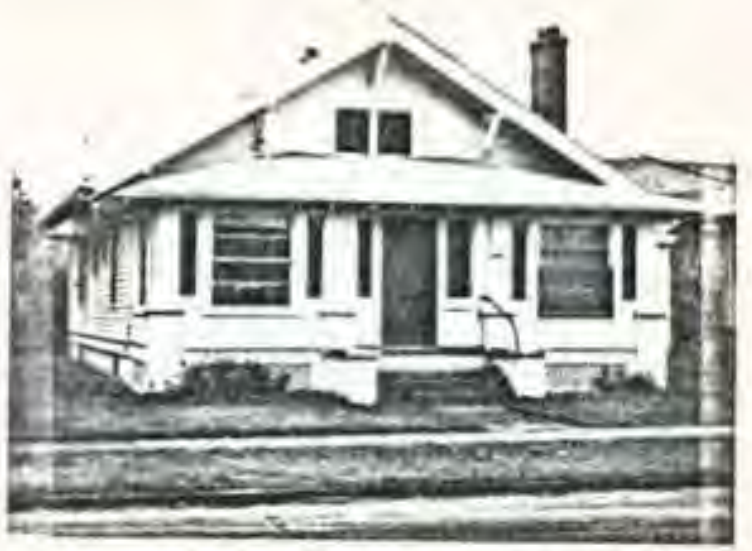

House with single frontal gable.

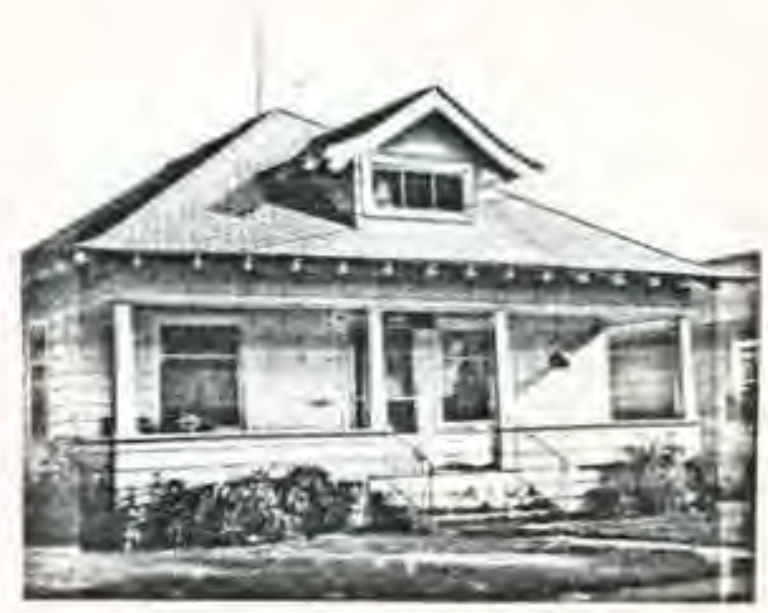

House with hip roof.

Figure 14. The four basic types of bungalows found in McMinnville, Oregon, 


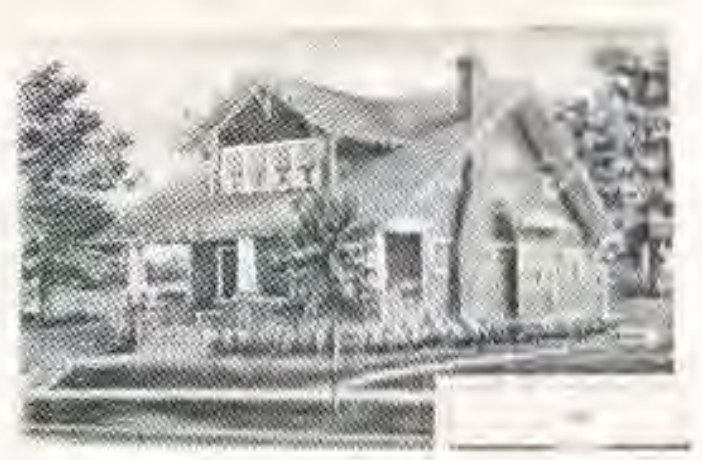

From Aladdin Homes, P. 81 .

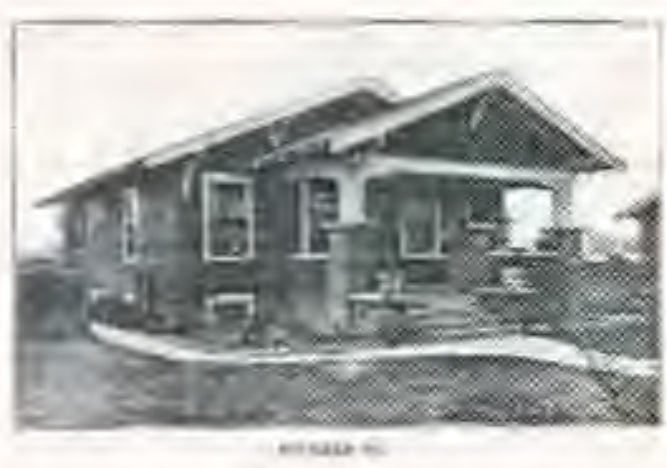

From Inexpensive Bungalows, P. 37.

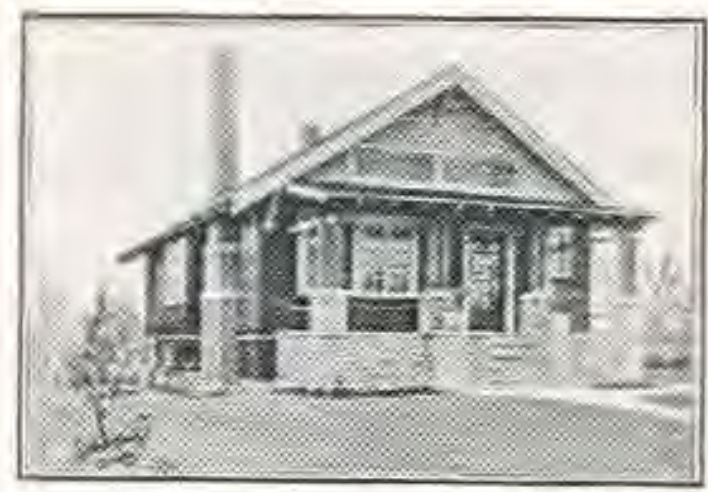

From Yoho, p. 78 .

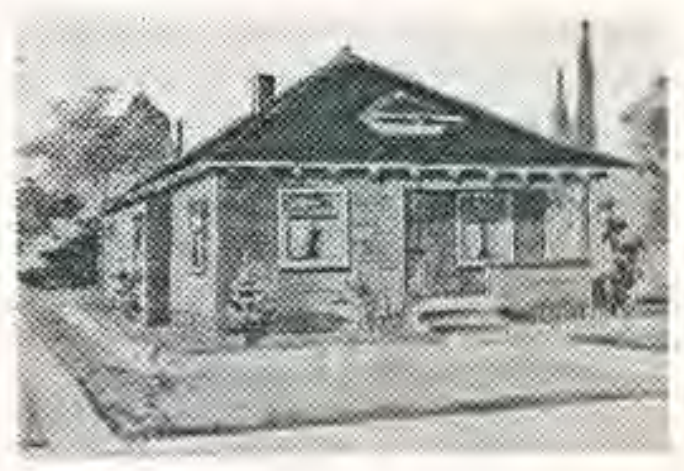

From Hodgson, Practleal Bungalows, No. 2007 . $\frac{\text { Figure 15. The four basic house types found in plan }}{\text { books? }}$ 
that year.91 The Telephone Register claimed in 1904 that more dwelling houses had been built that year than ever before and in 1905 that almost every neighborhood in town had one or two houses under construction.92 The Cicy Council found it necessary in 1908 to pass an ordinance regulating the moving of buildings within the city and that same year, the newspaper referred to the city's "building fever," and listed several construction projects which were underway, 93 The carpenters, it was reported later that year, were all working, dwelling construction represented an expenditure of $\$ 120,000$, and McMinnville Planing Mill was. forced to run until nine o'clock every night. 94 "There is so much 1 mproving going on," claimed the writer of a 1909 article, "that contractors are in each others' way."95 By contrast, nearly all of the interviewees questioned corroborated what the Samborn maps show; they recalled that building was slow from 1909 to 1922 ; most said that bullding never really boomed in McMinnvilie, that growth was always very gradual. The newspapers, it seems, were indulging in wishful boosterism.

91 The Yamhill County Reporter, February 16, 1900 , supplement.

92 The Telephone Register, December 31, 1904, p. 8; April 1, 1905, p. 6.

93McMinnville City Council, "Minute Book 7," August 4. 1908. P, 290; The Telephone Register, May 15, 1908, p. 1.

94The Telephone Register, September 4, 1908, p. 1; September 18, 1908, p. 5.

95 The Telephone Register, July 2, 1909, p. 6. 
A number of builders worked in the bungalow style from 1909 to 1922. Some of them built speculatively. One who constructed several bungalow-style cottages between 1905 and 1920, James Bickford, speculated often. His work was in the simplest, one-story mode with only minimal ornament and he sold his houses for an average price of $\$ 1,200.96$ The team of John Cook and Albert Arthur built several substantial bungalow-style houses. They were listed in the 1912 Yamhil1 County Directory as general contractors and there is no record that they speculated. 97 Vernon Derby was the builder responsible for a rather elaborate, two-story, bungalow-style house for which he may have drawn the plans himself, yet he worked as a builder in McMinnville only a few years and began his career as a flour and feed agent, 98 Dwight Miller was one of the busiest and most versatile builders in MeMinnville from 1908 until the 1960 's, Miller began his career by building small, unpretentious bungalows and ended it by constructing many of the major buildings on the Linfield College campus. Miller did not build speculatively and did not contract his work; he hired carpenters and

96Yamhil1 County, Deed Records, 71:332 and 77:211; $62: 164$ and $63: 17$; interview with Ruth Bickford McCa11.

97Polk's Yamhill and Washington Counties Directory, 2:64, 71; The Telephone Register, April 8, 1910, P. 5.

980regon and Washington State Gazatteer. 1903-1904, p. 242; 1905-1906, P. 284; 1907-1908, P. 292; 1909-1910, p. 236 ; V. L. Derby, BLUEPRINTS, McMinnville, n. d. 
worked for wages himself, 99 Evidence suggests that few trained architects worked in McMinnville, and none have been associated with the bungalow fdiom, During the bungalow period, however, one architect--E. N. Larry--drew plans for a residence which exhibited characteristics suggestive of the bungalow style, 100

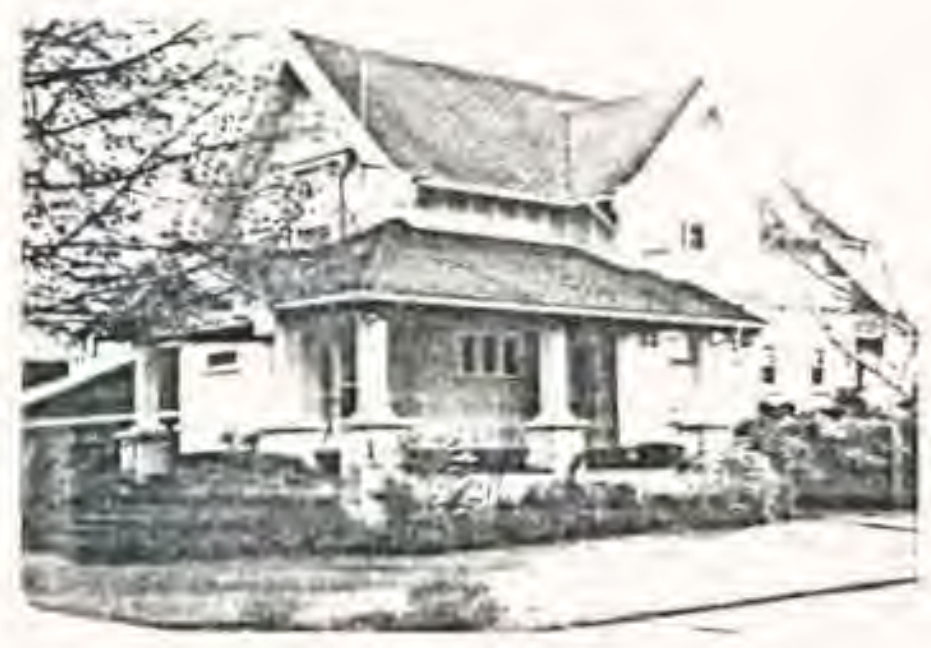

Figure 16. The Frank Rogers Fiouse, built by E. N. Larry, 1912 .

The few industries upon which the building trades relied flourished in McMinnville in spite of the leisurely pace of construction, By 1900, the town had supported a sash and door factory for many years. 101 In 1907 the

${ }^{99}$ Interviews with Nina Miller: Harry Leslie Dillin, McMinnville, Oregon, February 3, 1981; Howard Miller, McMinnville, Oregon, January 26, 1981; Velton Bynum, telephone interview, February 1, 1981; Polk's Yamhill and Washington Counties Directory, 2;95.

$100 \mathrm{E}$. N, Larry, BLUEPRINTS, Frank E, Rogers Residence, McMinnville, Oregon, 1912; Polk's Yamhill and Washington Counties Directory, 2:90.

${ }^{101}$ The Telephone Register, January 21, 1905, p. 6. 
McMinnvilie Planing Mill, located on the major business artery, bought new machinery and built a two-story addition to its existing plant, 102 It was reported that the mill employed a $\$ 24,700$ payrol1 during 1910 and that it shipped $\$ 32,664$ worth of millwork to other cities during the same period, revealing that McMinnville's own building did not Eully support it. 103 The mill was acquired by Charles Spaulding and was still operating in 1928.104 By 1912 a Lumber supply outlet which advertised shingles, lath, doors, windows, mouldings, sand and brick had been established in McMinnville.105 Several sawmills served the community: Jones and Adams had built a mill on the Nestucca River in 1903, another was erected west of town in 1905, and the small city of Carlton, northwest of McMinnville gained a sawnill the same year, 106 Jacob Seitters had established a brick and tile factory in McMinnville in 1888, expanded in 1902, and by 1903 produced 28,000 bricks a day, 107 Two

102Polk's Yamhill and Washington Counties Directory, 2:93: The Telephone Register, April 19, 1907, P. 6. ${ }^{103}$ The Telephone Register, January 13, 1911, p, 1 , ${ }^{104}$ Chamber of Commerce, Yamhil1 County Oregon, pp, 6,8 .

${ }^{105}$ The Telephone Register, Apri1 5, 1912, 0. 6; Polk's Yamhill and Washington Counties Directory, 2:72.

106 Yamhi11 Councy Reporter, May 29, 1903, p; 5: The Telephone Register, May 20, 1905, p. 6; April 29, 1905, p. 5.

107Gaston, 2:659-660: The Telephone Register, June 26, I902, p. 3; The Yamhill County Reporter, September 18, 1903, P. 8 . 
sources indicated that there had been a foundry in McMinnville between 1904 and 1920, and The Telephone Register reported the discovery of two stone quarries in 1905.108

Because McMinnville grew slowly during the bungalow period, real estate development was not dramatic, but measured. That did not alter the fact that people foresaw growth; investment in real estate was a very common enterprise. A 1902 city map reveals that most of an 1899 addition to the northeast part of the city, Oak Park Addition, was owned by a very few, among them an invescment company and a realtor. 109 By 1905 subdivision advertisements were appearing often in the newspapers, but parcels sold slowly. 110 During 1911 and 1912, advertisements for city lots in platted additions to the city appeared regularly,111 As already noted, builders sometimes speculated on a small scale, but there is no, evidence that large tracts were developed at one time, Many streets in McMinnville are graced with bungalows built by the same house plan, but usually in palrs or groups of three and not always on adjoining lots. (See Figure 17.) Most streets in older residential sections reveal that

108Interview with Howard Miller: The Telephone Register, December 31, 1904, p. 7; Apri1 15, 1905, P. 6; June 17. 1905, P. I.

${ }^{109}$ H. S. Maloney, "City of McMinnville, Oregon, 1902," MAP, McMinnvilie, 1902.

110 See The Telephone Register, April 8, 1905, p. 5.

111 See The Telephone Register, April 7, 1911, p. 4; July 21, 1911, P. 6; May 24, 1912, p. 5. 

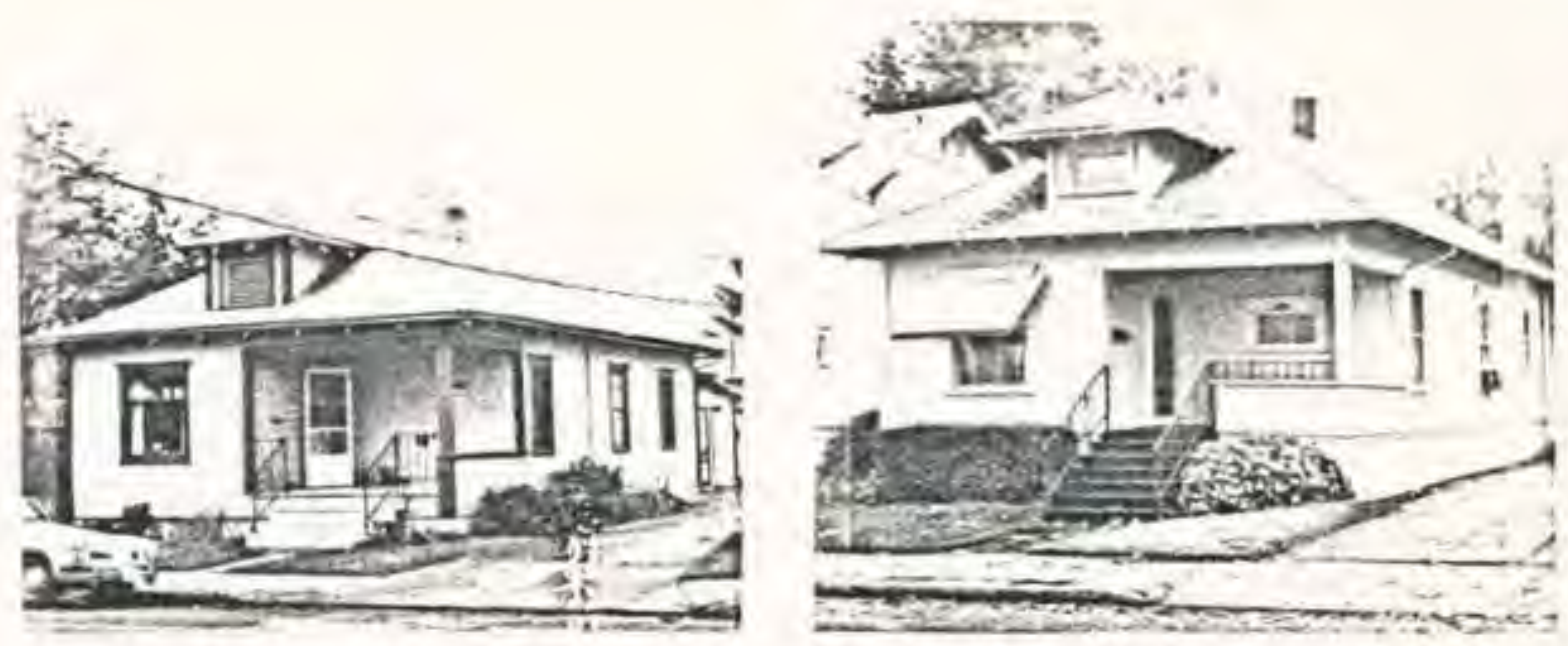

Two houses on North Baker Street, McMinnville, Oregon
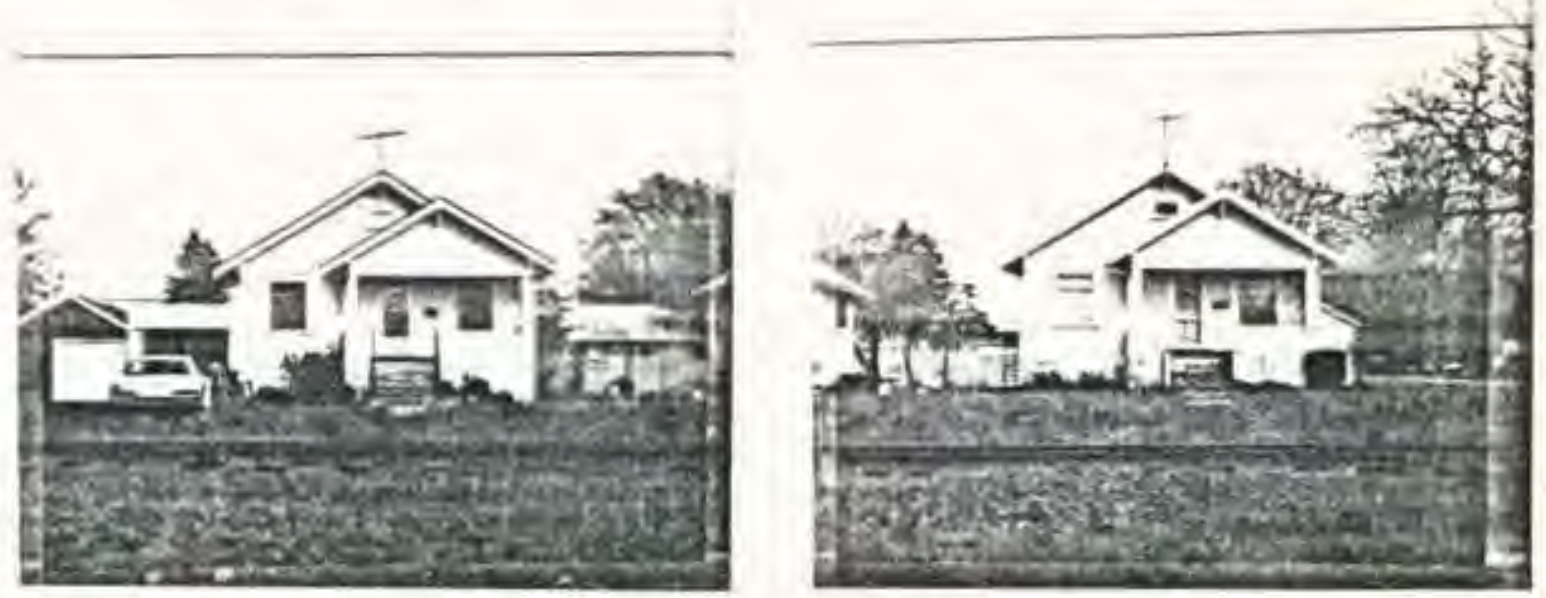

Two houses on South Hembree Street, McMinnville, Oregon.

Figure 17. Examples of houses built by similar plans in McMinnville, Oregon. 
building took place over a long period of time, leaving houses of different ages on the same block. The examples of speculative building which can be traced in deed records reveal the same thing; only a few houses were built at a time, and sometimes the empty lots were resold before being developed, 112 Even as late as the 1920's, speculative building was being done only on a small scale. The city recorder bought a piece of property four lots Iong on South Davis Street in 1921 and had four bungalow-style houses built on it. He advertised the houses throughout 1921 and 1922, and his daughter recalled that the venture was not a financial success. 113

Edith Allen found that only 40 percent of all American families owned their homes by 1920.114 By contrast, newspaper ttems, deed records, and oral tradition all suggest that home ownership was far more prevalent in McMinnville, Oregon than elsewhere in the nation during the bungalow years. In the 1920 's, a McMinnville Chamber of Commerce publication boasted that "McMinnville is pre-eminently a city of homes and home owners."115 In 1921, the News

$112 \mathrm{~J}$ ames Bickford bought, built, and sold, in small volume. Yamhil1 County Deed Books $63: 635 ; 69: 366 ; 57: 78$, $488 ; 58: 80$, show examples of these transactions.

113 The (McMinnville) News Reporter, September 15. 1921, p. 4; January 12, 1922, Pp. 4, 5; Aleen Jacobs Fowler. telephone interview, March 22, 1981 .

114A11en, Pp. 132-133.

115 Chamber of Commerce, Yamhill County Oregon, P. 6. 
Reporter found that of the 2,592 farms operating in Yamhill County, only 500 were operated by tenants; the remainder, or 81 percent, were operated by either owners or managers. 116 Because McMinnville was homogeneous, moderately prosperous, and enjoying a slow but steady growth rate, people were able to buy their own homes, and between 1909 and 1922, they were buying bungalows.

The first car in Yamhill County was a steam-powered Locomobile which belonged to the grandsons of the bank president.117 A need for regulating the speed of the vehicles prompted a city ordinance to that effect in 1903.118 By 1908 advertisements for automobiles began appearing in the newspapers and several notices that year announced purchases of the new machines. The automobile had arrived concurrenty with the bungalow style,119 Both travel and housekeeping had become easier. In 1922 a promotional pamphlet claimed that there was an automobile for every 6,5 persons in Yamhill County. 120

116 The News Reporter. February 17, 1921, p. 1.

117 Dorothy Wortman Gunness, So This Is What We're Made Of: (McMinnville, Oregon: Oregon Lithoprint, Inc., 1967), P. 115.

118 McMinnville City Counc1l, "Minute Book 6," hugust 4,1903, p. 235.

119 The Telephone Register. April 24, 1908, pp. 6-7, April 17. 1908, p. 5; May 15, 1908, p. 6.

120Yamhill County Federation of Commercial Clubs, Yamhil1 County Oregon (n. P.. 1922), p, 4. 
The major influences which brought the bungalow style to McMinnville were economy, to some extent life style, possibly the advent of home economics, but certainly fashion and successful promulgation. In 1911 the McMinnville Land Company advertised that a bungalow could be purchased for $\$ 1,600.121$ Whether or not women planned the bungalow-style floor plans and room arrangements, they did find them convenient, and this influenced the popularity of the style. All the McMinnville interviewees remembered that either they or their mothers read women's magazines during the bungalow era and at least seven of them mentioned specificially, the Ladies' Home Journal.

The houses McMinnville residents were building prior to the bungalow age were typical of homes popular throughout the late Victorian period in America: some had Queen Anne features, some exhibited neo-colonial characteristics, and many were of the simple style sometimes called Willamette Valley rural vernacular. They were usually two-story and quite tall because the ceilings were high. Most had parlors and stairway entries. Rooms were usually separate and closed. (See Figure 18.) There are striking examples of the sudden change in taste to the bungalow style. James Bickford, a man who built a number of bungalows from 1910 to 1922 and lived in at least one of them, built his first house in McMinnville in 1904 in the traditional mode. It 

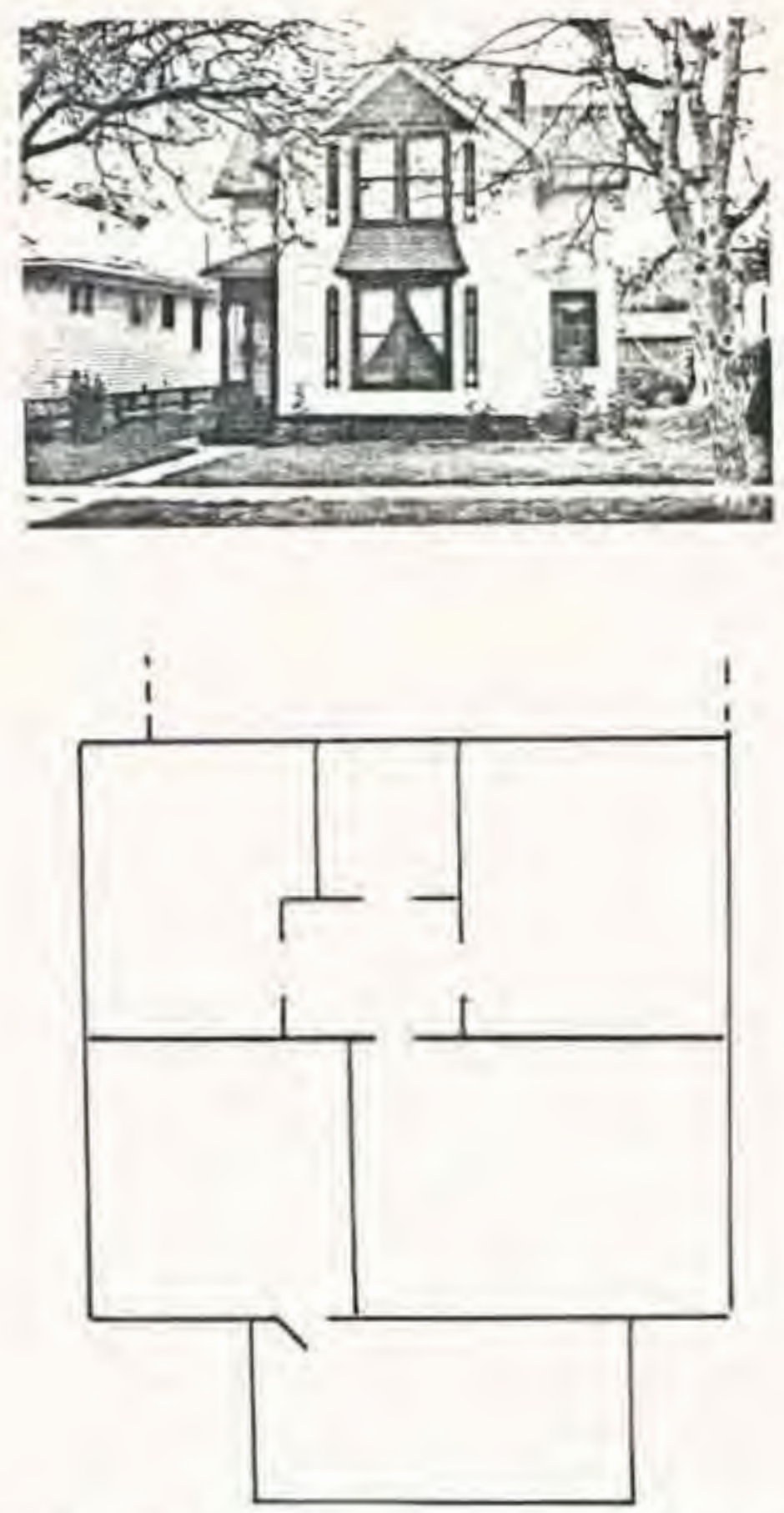

Figure 18. Photograph and floor plan of a MeMinnville house built just prior to the bungalow age. 
was a tall, two-story structure with tharrow eaves, Queen Anne ornament, and a small porch. The interior floor plan included a parlor. 122 As the bungalow era dawned, houses with colonial elements were being built and concurrent with the appearance of the bungalow style was the construction of several homes in the dormered box style in McMinnville. These houses often exhibited characteristics common to the bungalow--exposed rafters, heavy porch posts with stone piers, and wide eaves--but they were two-story and their floor plans were usually traditional. (See Figure 19.)

As shown earlier, mail-order plan books published all over the country were available through magazines. There were also local building companies who sold bungalow plans and pre-cut houses throughout the early 1900's. One of the Largest national firms to sell pre-cut houses, Aladdin Homes of Bay City, Michigan, established a Northwest branch in Portland, Oregon in 1919. The company had begun selling ready-cut homes--entire houses shipped unassembled--as early as 1904 and when the twenty-acre Portland plant was built. Aladdin Homes were being shipped overseas. 123 By 1921 the

122 Interview with Ruth Bickford McCall.

123An interesting item in The Oregon Sunday Journal of October 25, 1925, claimed that orders for Aladdin's sixroom bungalows had been received from Bombay; the bungalow was returning home. 

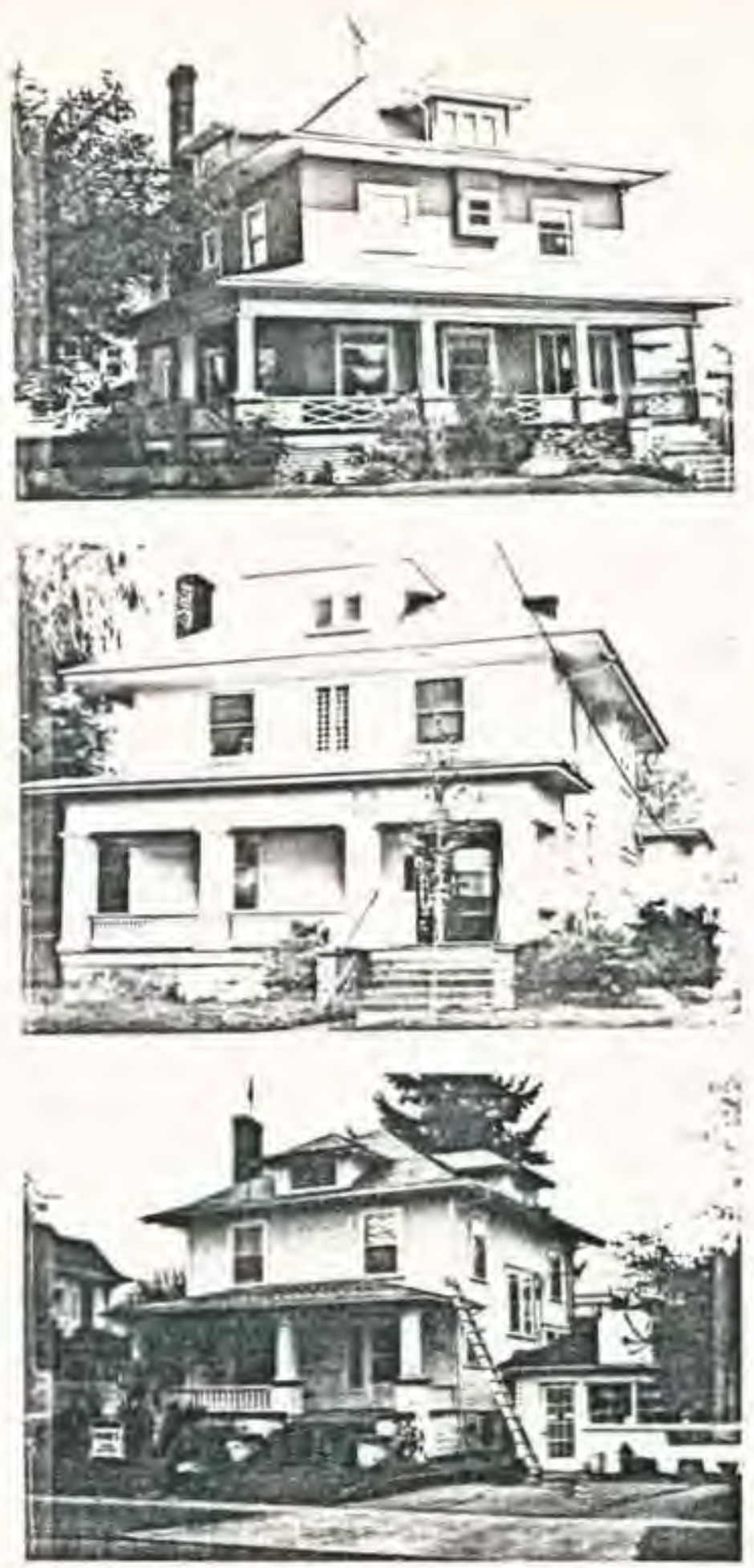

Figure 19. Three examples of McMinnville, Oregon homes built during the bungalow era, but in the dormered box style. 
Portland plant could produce sixty houses a day, 124 Figure is shows an Aladdin house resembling a common cype found in McMinnvilie.

Another Portland firm which advertised factory-cut homes from 1912 until 1929 was Fenner Manufacturing Company owned by lumberman, J. Harvey Fenner. Fenner also advertised mail-order, unassembled houses and he shipped as far away as Iowa. The company advertised that houses were shipped in one box car, complete with instructions for amateurs, 125 (See Figure 20,)

The Portland building company which left the most striking examples of its influence in McMinnville was established in 1907 by Henry J. Fancher, realtor-turnedarchitect. 126 Fancher did not advertise ready-cut houses, but he sold plans through books published by his Bungalow Book Publishing Company probably in 1915 or 1916.127 Two

124 The Aladdin Homes, pp. 2, 3; The Oregon Daily Journal, October 23, 1919, p, 14; The Portland Telegram, January 4,1921, p. 1.

125Fenner Homes of Distinction, P. 1; Portland City Directory, 1911, P. 515; 1912, p. 535, 1913, P. 445; $1914, p, 558 ; 1918, p, 432 ; 1929$, The Portland Telegram, December 3, 1919, p, 17: August 19, 1922, p. 10.

126 Portland City Directory, 1905, p. 404; 1906, p. 410,1907, P. 512; 1914, P. 551; The Craftsman Book of Bungalows, title page.

127 The plan book available has no date and the Bungalow Book Publishing Company is not listed in the Portland City Directories. H. M. Fancher and Co. was listed as such only until 1914. 


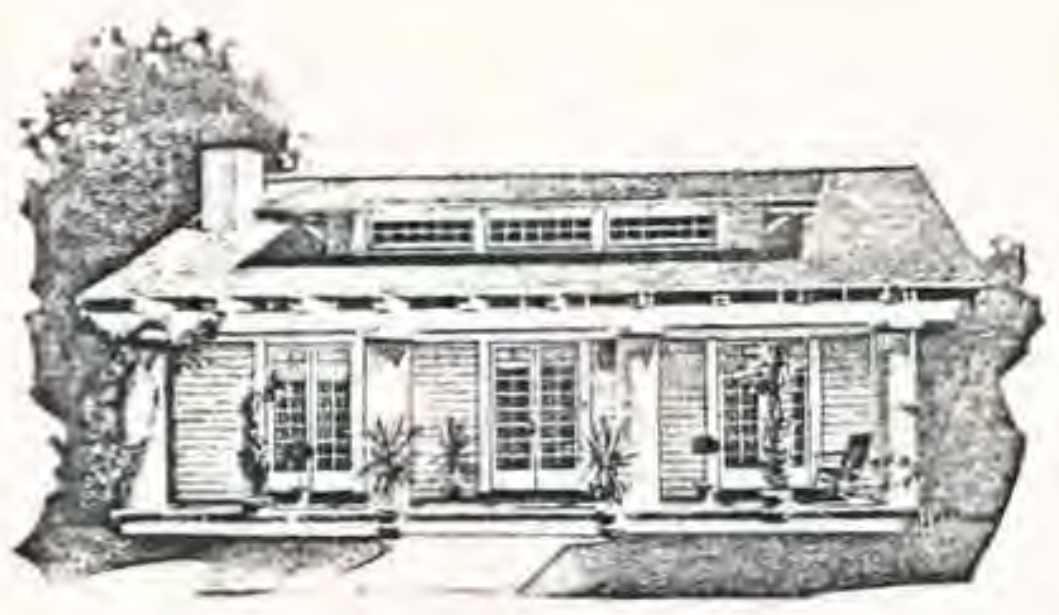

\section{Fenner Home No. 902}

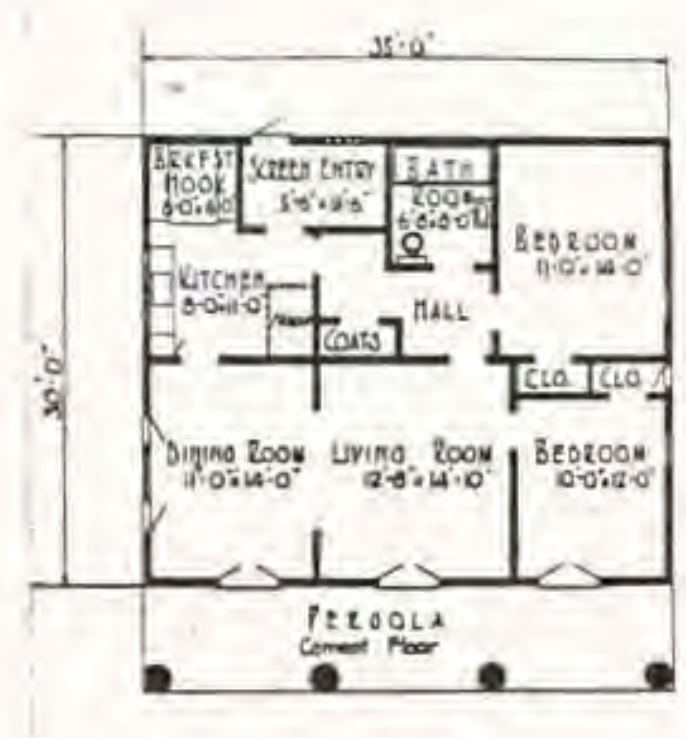

Figure 20. From Fenner Homes of Discinction, No, 902 . 
of the homes pictured in his second edition have identical councerparts in McMinnville, but these will be treated in detail in the next chapter.

In 1921 McMinnville builders were supplied with a ready-cut outlet at home. Former flouring mill operator, F. C. Barnekoff returned to McMinnville after an absence of some years and established a ready-cut house business. He advertised that he furnished "everything complete, except. brick, plumbing, and concrete."128 Spaulding Lumber Company advertised the arrival of the "latest plan book of houses. barns, and garages," in 1921, further evidence that plan books influenced house style. 129

McMinnville, Oregon experienced social and cultural changes which in some respects paralleled national trends From 1900 to 1920 , but the town also exhibited exceptional characteristics: a relatively stable population, homogeneity, and an agricultural economy. The town did follow the middle-class pattern of building bungalows at the same time that towns elsewhere were doing so, and thus, underwent physical change.

128 The News Reporter, February 17, 1921, pp. 7, 8. 129 Ibid., p. 3. 
CHAPTER V

MCMINNVILLE BUNGALOWS: TWENTY-ONE CASE STUDIES

It has been shown that McMinnville was racially homogeneous and economically stable during the first two decades of the twentieth century. Yet there were varying levels of economic, educational, and professional status within this relatively uniform population, and people at all levels in McMinnville built bungalow-style houses. This chapter will demonstrate more fully that people chose the bungalow primarily because of fashion and availability. Examination of the houses themselves may lend understanding to the significance of other factors. The case studies which follow will range from the simplest to the most elaborate.

SPECULATIVE HOUSES: THE BICKFORD BUNGALOWS

James Bickford was mentioned in an earlier chapter as an example of a McMinnville builder who speculated. It was noted, too, that Bickford began his building career in MeMinnville with the construction of a traditional Queen Anne house in 1904. As a speculative builder, he was quick to embrace the fashionable bungalow style and the only evidence available indicates that he built in the new fdiom 
From 1908 until the 1920 's, James Bickford brought his family to McMinnville from his native Iowa in 1904 at the age of 54. According to his daughter, he chose to build in the bungalow style for, two reasons; it was affordable and it was popular, 1

Three of James Bickford's bungalow-style houses are pictured in Figure 21. Their similarities suggest that they were all built from a single house plan. The house at 1035 North Hembree has undergone changes but the essential characteristics remain: a gable roof with a single shed dormer, a secondary gable sheltering a small cutaway porch, exposed tafters, brackets, and broad. slightly upturned eaves. These bungalows were very simple and relatively inexpensive, of the three, on $1 y$ the house at 1035 North Hembree has a basement, and all three have only storage space in their attics. The floor plans are very uncomplicated, too, Figure 22 Illustrates the plans of the two houses on Hembree Street. They are similar, but reversed. Structure is exposed in the attic space and reveals typical framing: two by four studs at sixteen-inch intervals.

The interiors of these houses reflect a simplified manifestation of the bungalow aesthetic. The typical arch connecting the living and dining rooms is a simple beam with partial side partitions which form shelves. A built-in thina closet in the dining room of each house is a very plain

Interview with Ruth Bickford McCall. 


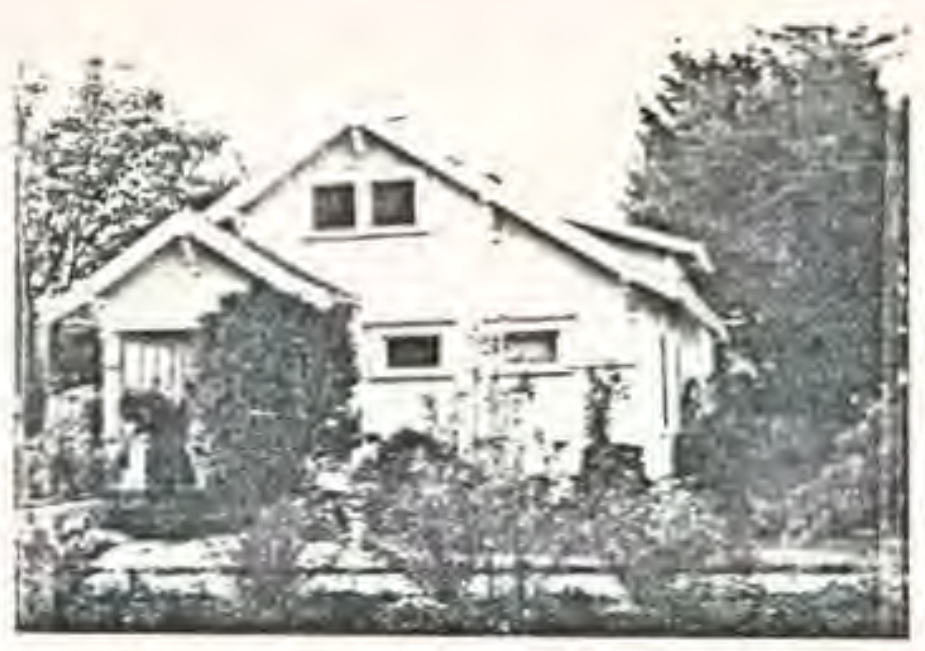

124

1103 North Hembree Street

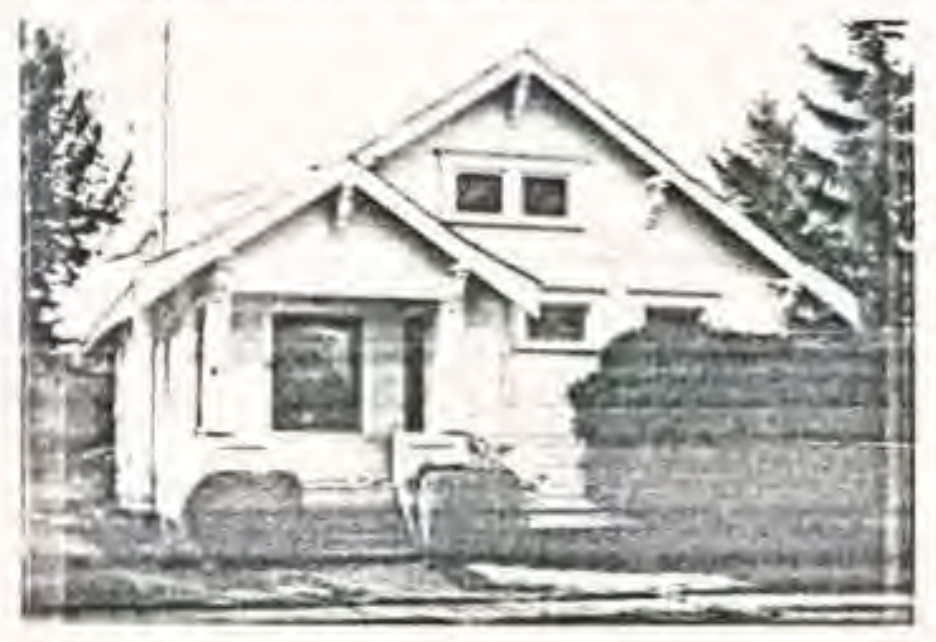

1015 North Ga1loway Street

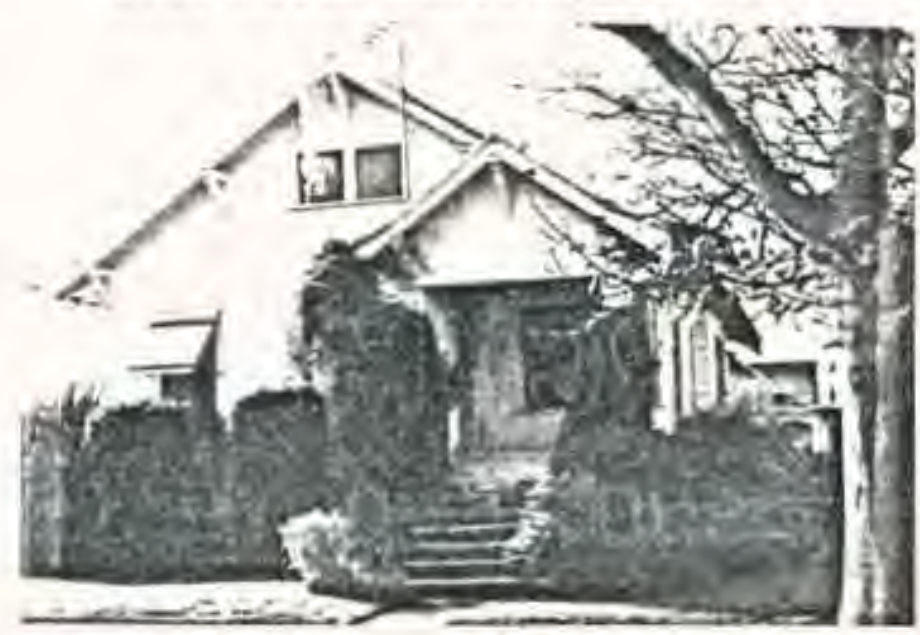

1035 North Hembree Street

Figure 21. Three McMinnvilie, Oregon bungalows built by James Bickford between 1912 and 1915. 

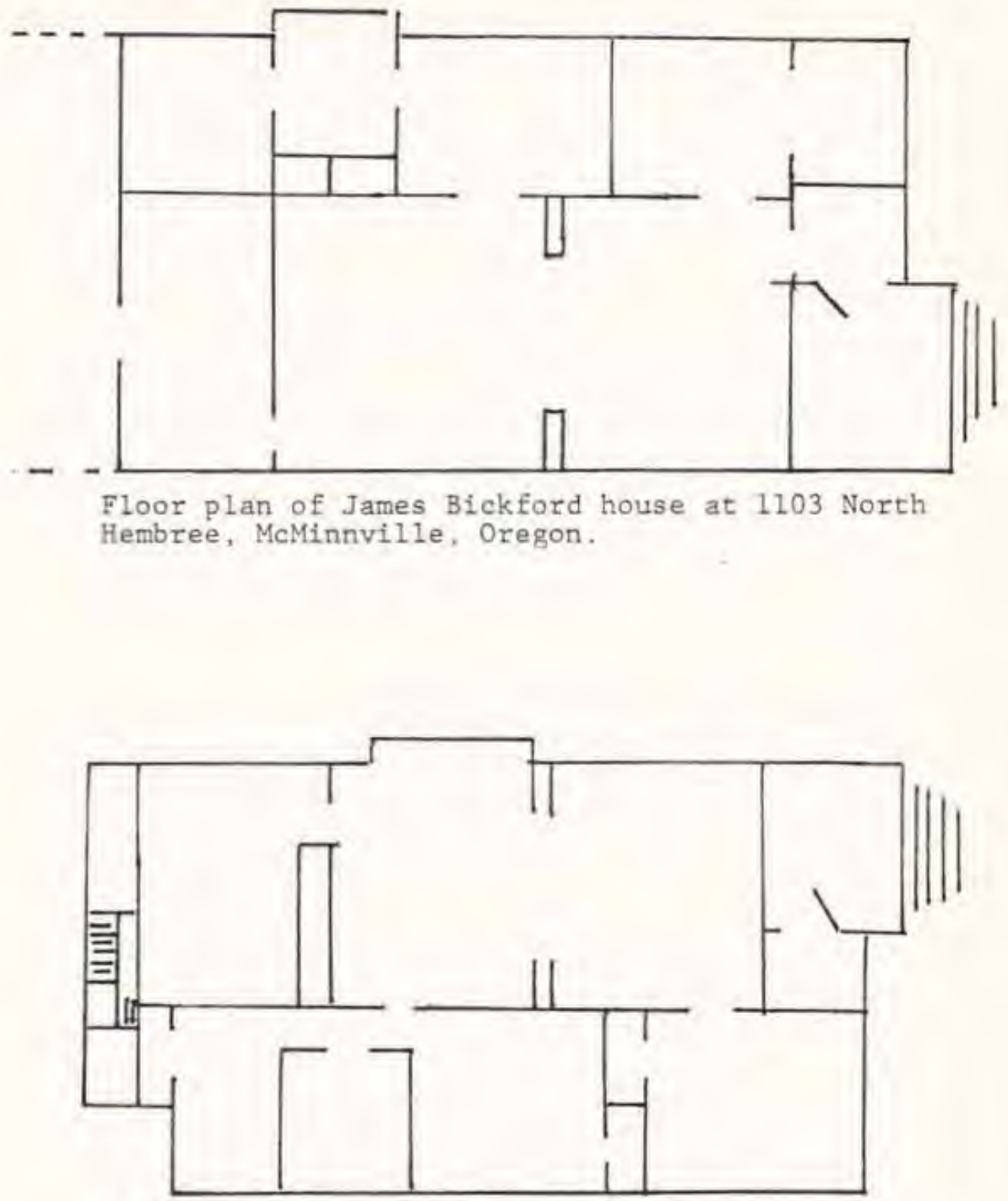

Floor plan of James Bickford house at 1035 North Hembree, McMinnville, Oregon.

Figure 22. Floor plans of two houses built by James Bickford, McMinnville, Oregon. 
cupboard with simple glass-paneled doors. Woodwork and flooring throughout was originally varnished fir.

The house at 1035 North Hembree was built on two lots which were part of a five-1ot purchase Bickford made in 1912 for $\$ 700$; their cost to him, then, was approximately $\$ 280$. After building the house, he sold the property to A. H. Leland, a cigar store and restaurant operator, for $\$ 1,800$ in 1915. Assuming the property was by then worth at least $\$ 300$, the house sold for $\$ 1,500$, a fairly inexpensive home, even in 1915.2

In 1911, Bickford's daughter bought, for an undisclosed amount, the lot on which the house at 1103 North Hembree sits. In 1912 the property was sold to a painter, Gilford L. Zumwalt, for $\$ 1,325,3$ If the lot were worth $\$ 150$, this house sold for under $\$ 1,200$. The difference in its price and that of its neighbor is probably due to the fact that it had no basement.

These chree houses are situated in an area with a oneblock radius, but they are not on adjacent lots; thus they conform to the observation that development did not occur in large plats.

${ }^{2}$ Yamhil1 Councy, Deed Books 63:635: 69:366: Polk's Yamhi11 and Washington Counties Directory, 2:90.

${ }^{3}$ Yamhill County, Deed Books 62:164; 63:17; Polk's Yamhill and Washington Counties Directory, 2:114. 
THREE COMMISSIONED BUNGALOWS

The earliest bungalow style house found in this study was built in 1909 for Frank Wortman, the new1y-married son of a local bank president. The house was built by his fatherin-law, David H. Turner. 4 Like the Bickford houses, this is a simple, single-story bungalow. The plan reflects the transition between the traditional plans of closed rooms and the newer ones with open spaces, for it contained a parlor and a sitting room. (See Figure 23.) Sliding doors made it possible to join the two spaces but the Wortmans' daughter recalls that the doors were usually closed. The basement was unfinished and the attic contained just two rooms. Built-in kitchen cabinetry, common to later bungalow style houses, was added only after the house had stood for some years, 5 Frank Wortman was the grandson of Jacob Wortman who founded the first bank west of the Willamette River in McMinnville in 1883,6 When he and his bride moved into their small bungalow, he was making $\$ 100$ per month, and a smal1 house seemed fit, 7 But eight years later, the Wortmans purchased the Turners' house next door and thus moved from a bungalow into a much older home, a reversal of the usual

${ }^{4}$ Gunness, So This Is What We're Made Of: . P. 257.

Interview with Dorochy Wortman Gunness.

6Gunness, So This Is What We're Made Of: , p. 60-80. 7 Ibid., p. 156. 

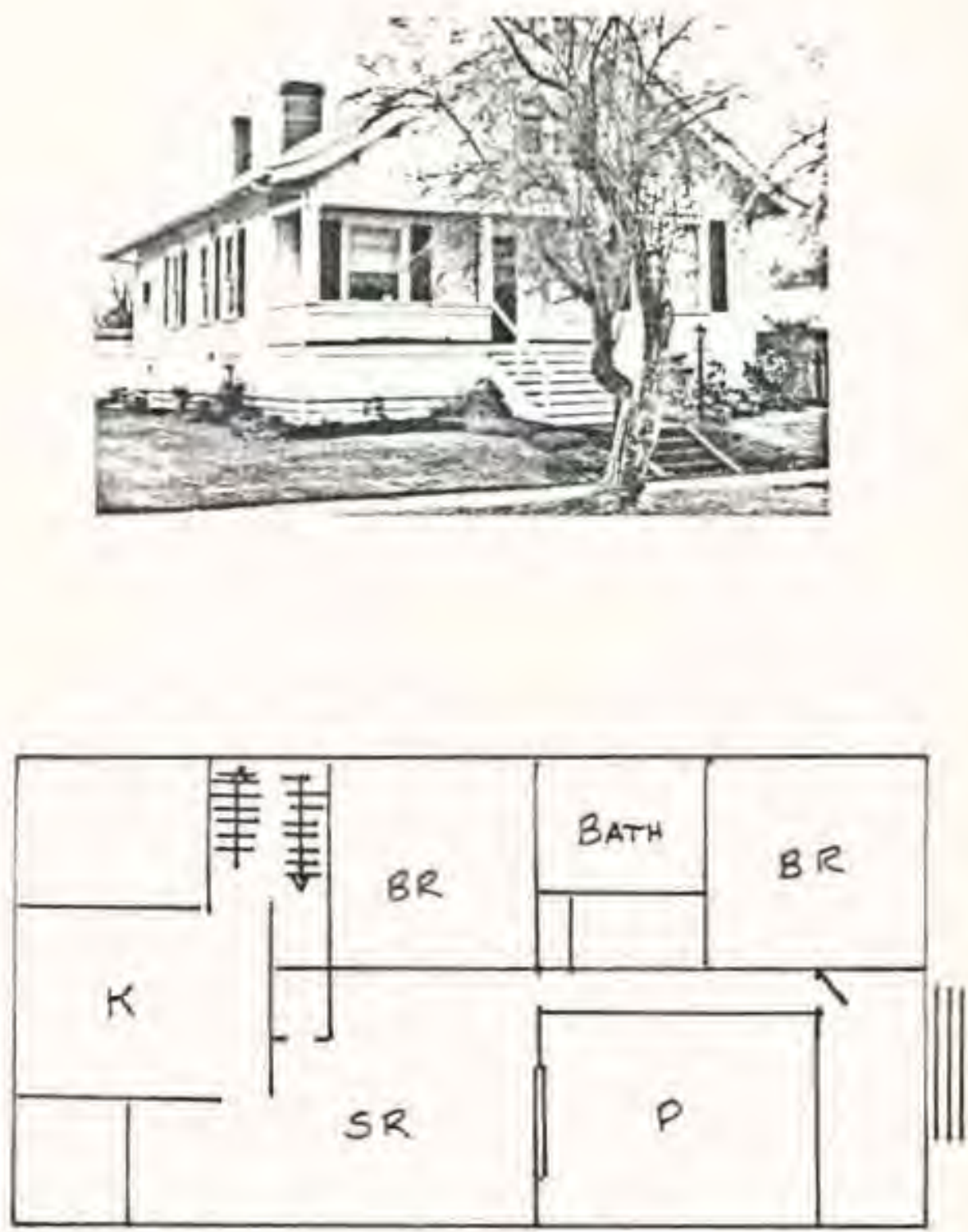

Figure 23. Photograph and floor plan of house built for Frank and Carrie Wortman, McMinnville, Oregon, 1909. 
pattem. The Tumer House had a nineteenth-century room arrangement: a large stairway entry, a separate parlor, and sitting and dining rooms connected by sliding doors. In 1927 , in order to modemize, the Wortmans opened the entry, sitcing room, and parlor into one large area, following the pattern established by bungalow interiors, 8

Another simple bungalow built for its owner was the Dwight Miller House. (See Figure 24.) Miller was mentioned earlier as one of the most prolific and highly regarded builders in McMinnville for nearly half a century. This house was erected for his parents sometime between 1912 and 1918, and he and his wife lived there after their marriage in 1930.9 More care and expense were invested in the construction of this house than in those built for speculation. Its exterfor is simple, but the interior is more elaborate. The floors are oak, the fireplace is made of decorative picture tiles, and the doors on the bullt-in china closet in the dining room have panes of leaded glass: Both exterior and interior are typical and it is reasonable to assume, because there are so many similar houses of this type throughout McMinnville, that its design came from purchased plans.

8Interview with Dorochy Wortman Gunness,

${ }^{9}$ Interviews with Nina Miller and Howard Miller. The Millers are not listed at this address in Polk's Yamhill and Washington Counties Directory of 1912 and an inscription in the sidewalk probably poured after the house was built, reads: "D. Miller, 1918." 

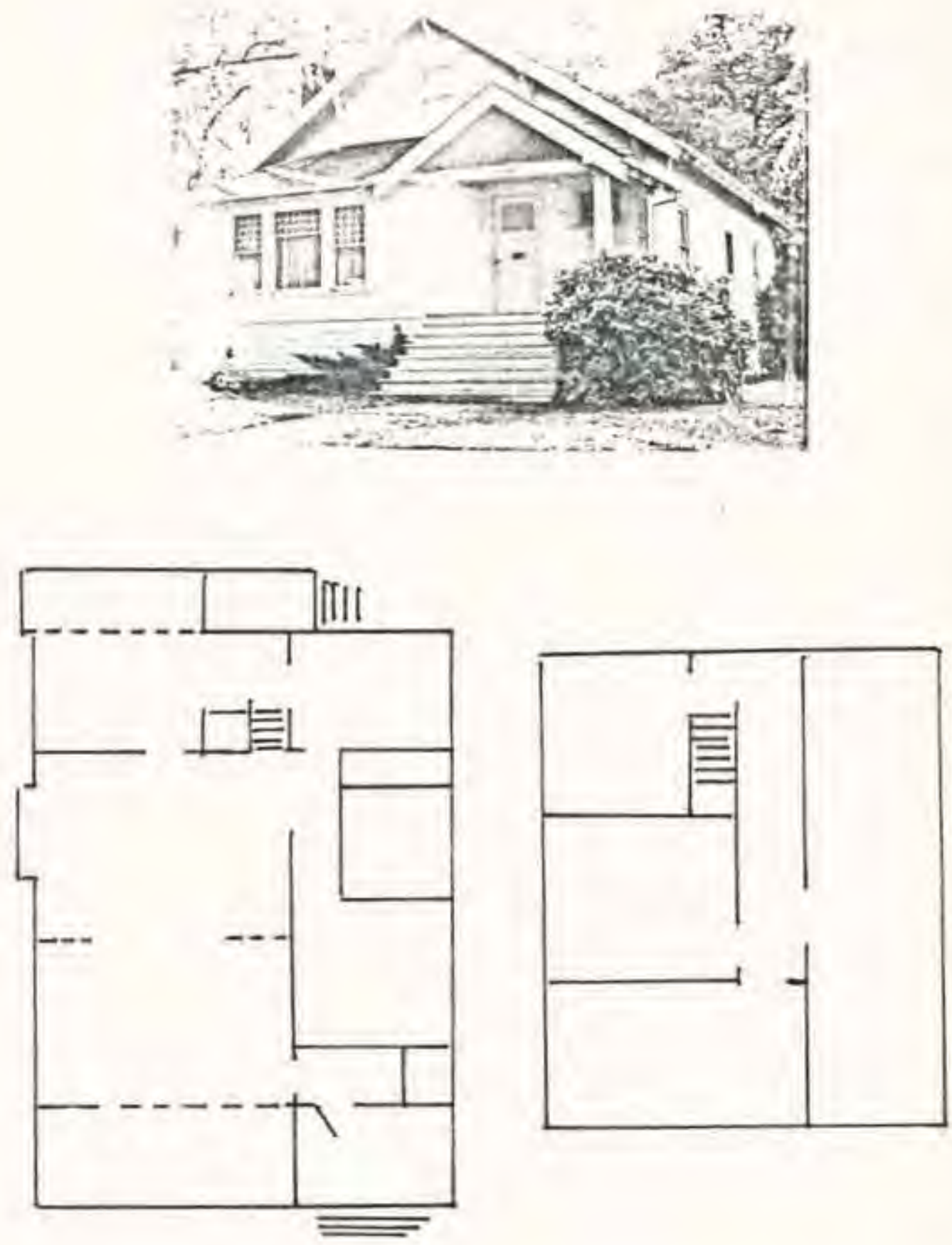

Figure 24. Photograph and floor plan of the Dwight Miller house, McMinnville, Oregon, built between 1912 and 1918 . 
McMinnville's first wail carrier, Kirk P. Loop, built the one and one-half story bungalow pictured in Figure 25 in 1913,10 The Loops had already built one new home in MoMinnville; they had erected a two-story traditional home with classical porch column in 1908, just five years earlier. 11 That the change meant altering habits to conform to the typical bungalow interior is obvious, but assigning this as a motive for the move is speculation, for the Loops' daughter remembers that the reason for the change in location was to be nearer a school as she and her brother grew older. 12

The interior of the Loop House is more elaborate than either the Bickford or the Miller Houses. The dining room walls are paneled with fir wainscoting topped by a brackeced platerail. There is a window seat in the large bay of the dining room window, and a built-in china closet with scorage drawers beneath dominates one wall. The entry had originally been divided from the living room by varnished wood posts over leaded-glass bookcases. The balustrade on the staircase, to the side of the entry, is of a simple, geometric design with a square newell post, similar to many in bungalow-style houses. Unlike others examined, this house has sliding doors between the living and dining rooms, but

10Interview with Arleta Loop Shotwell.

11The Telephone Register, May 15, 1908, p. I; photograph, Arleta Loop Shotweil collection, McMinnville, Oregon.

12 Interview with Arleta Loop Shotwe11. 

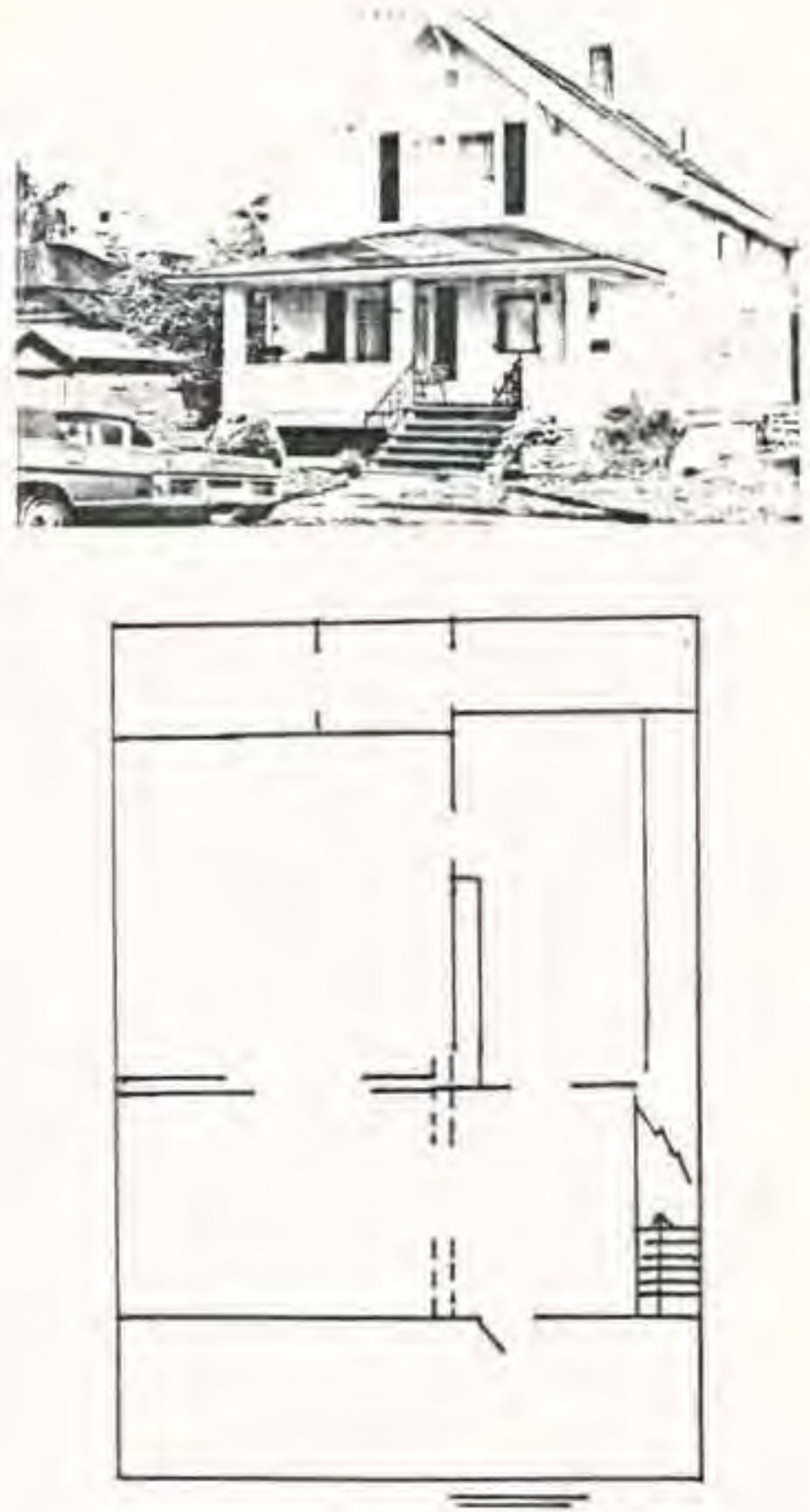

Pigure 25. Photograph and floor plan of the Kirk $\mathbb{P}$. Loop house, McMinnvilie, Oregon, built in 1913. 
they are wide enough to afford a large continuous space when opened. The Loops' daughter does not remember the reasons for adopting the new bungalow style after having lived in a more traditional home but she remembered that the family spent the majority of their time making use of the diningliving room open space. She said the sliding doors between were never closed, 13

\section{FIVE SUBSTANTIAL BUNGALOWS BUILT BY MERCHANTS}

An item in a 1910 Telephone Register announced;

Franz Dielschneider is planning to build a modern bungalow on his lots on North D. Street. Work will begin at once by Cook and Arthur, 14

The houses built by John Cook and Albert Arthur were sturdy and substantial. There is no record of what the Dielschneider bungalow cost, but it is more elaborate than those examined thus far. (See Figure 26.) The entry is large and appears to have served as a separate living space at one time. The arch connecting the living and dining rooms has unusually large posts and the dining room has wainscoting, platerail, and large exposed ceiling beams-a feature common to the more expensive bungalows. The mantel is simple, but the fireplace is made of unusual

13Interview with Arleta Loop Shotwe11. 14 The Telephone Register, April 8, 1910, p. 5. 

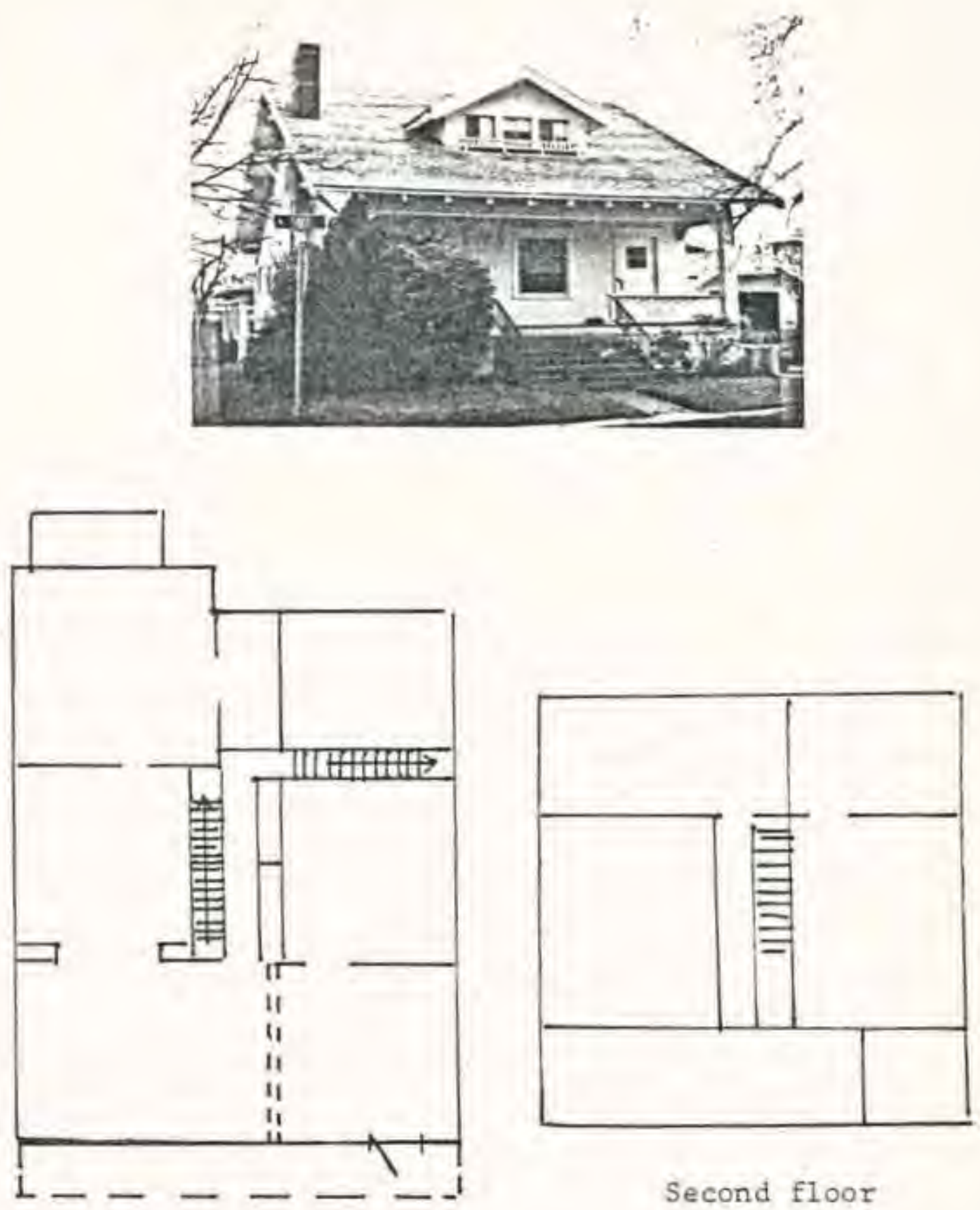

\section{First floor}

Figure 26. Photograph and plan of the Franz Dielschneider house built in 1910, McMinnville, Oregon. 
mottled tiles. The house is fairly large; it has a full basement, two bedrooms on the first floor, and three on the second.

Franz Dielschneider, son of McMinnville shoe merchant, Arnold Dielschneider, owned a jewelry business with his brother William until his deach in 1935,15 In 1909 he married Dorothy Hamblin, the daughter of another McMinnville merchant and it was shortly after their marriage that they chose plans for their new home. Mrs. Dielschneider's sister remembers that when she and Franz chose the bungalow, it was the new style at the time, and most people thought it better looking than the tall, two-story houses such as the Dielschneiders had rented when they were first married, 16

Alexander Cameron, a Scotsman who left the coal mines of Nova Scotia to seek his fortune in the Pacific Northwest wended his way to MoMinnville, Oregon in 1912 where he became the owner of a grocery business within two years. After renting quarters for a time, Cameron and his wife bought the house pictured in Figure 27 for $\$ 2,000$ in 1915.17 A picture in his son's collection carries the penciled note that a California contractor named Terry built the house in 1914, but the deed transaction shows that Cameron bought the

15 Gaston, 2:658.

16 Interview with Esther Hamblin DeHaven.

17 Interview with Ogden Cameron; Yamhi11 County, Deed Book 70:66. 

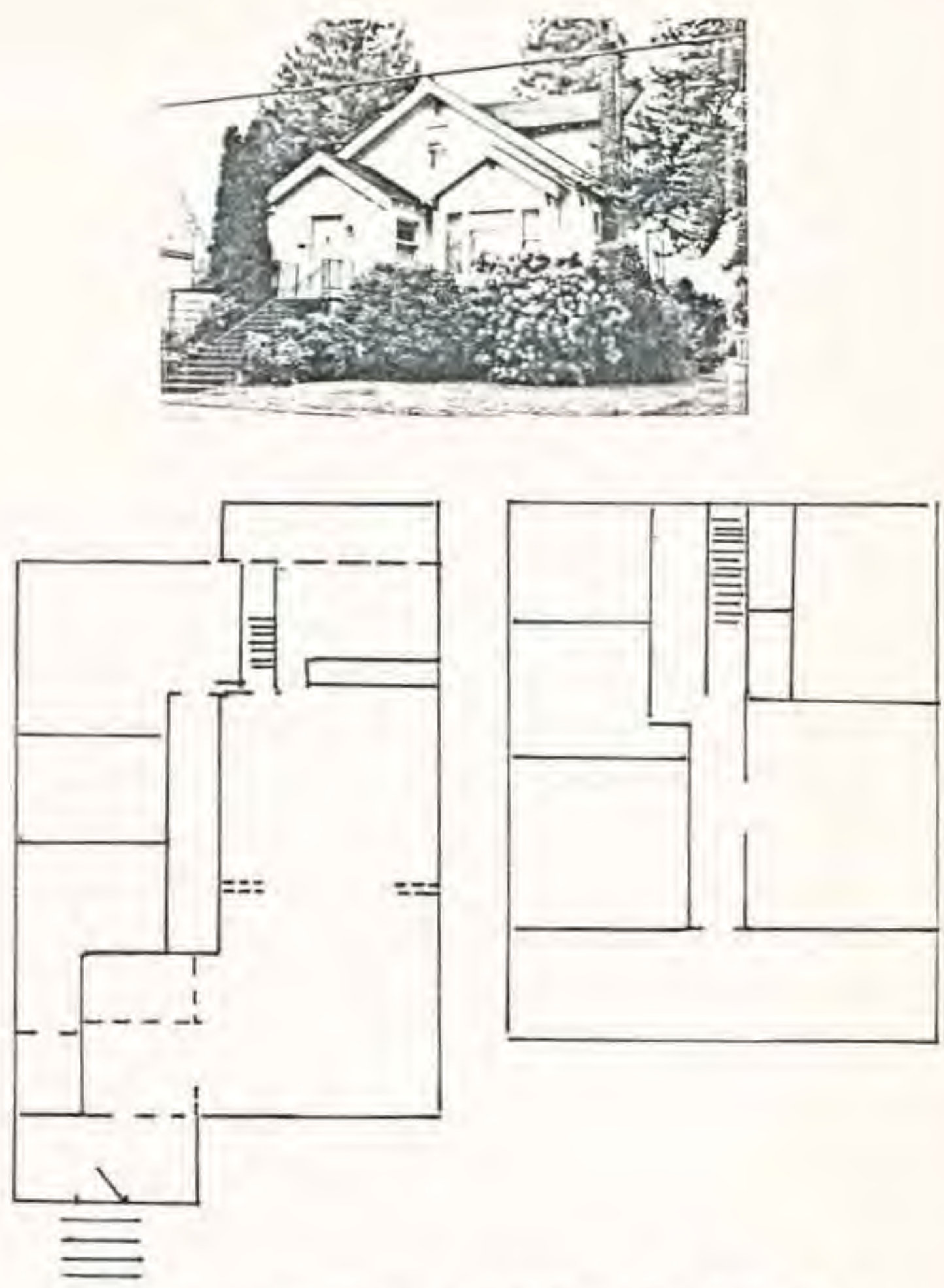

Figure 27. Photograph and plan of the Alexander Cameron house, built in 1913, in McMinnville, Oregon, 
house from william H. Feary, and a company named L. H, Fearey and Sons, Inc, was doing business in real estate during this period. 18 In any case, the house was probably a speculation house and despite the reasonable price (1t occupied two lots), it was larger than James Bickford's houses. It was also located farther from the city center, The plan sketch in Figure 27 shows that the first floor plan was typical.

The Camerons' son recalls that his father had chosen their new house but he also remembered that the main reason for the choice was 1ts number of bedrooms; the Camerons had a large family, 19 Convenience, price, and availability appear to have been the major factors in the selection of this bungalow, and the builder had dictated style.

Three houses built between 1912 and 1921 in the common, one and one-half story style which had a deep porch under the sloping side of a wide gable roof are pictured in Figure 28. They were all the homes of business people.20 The John Gordon Baker House has been changed considerably and its original floor plan has been lost, but the Sarah Hopfield House, built in 1912, and the C. C. Jacobs House built in 1921 are examples of two common floor plans. (See

18Ibid.; Yamhil1 Councy. Indirect Index to Deeds, Book 6, McMinnville, 1913-20.

19 Interview with Ogden Cameron.

20 Yamhil1 County. Deed Book 65:595; The Telephone Register, February 23, 1912, P. 6: Iva G. Tievrance, BLUEPRINTS, 3 sheets, n. p., n. d. 

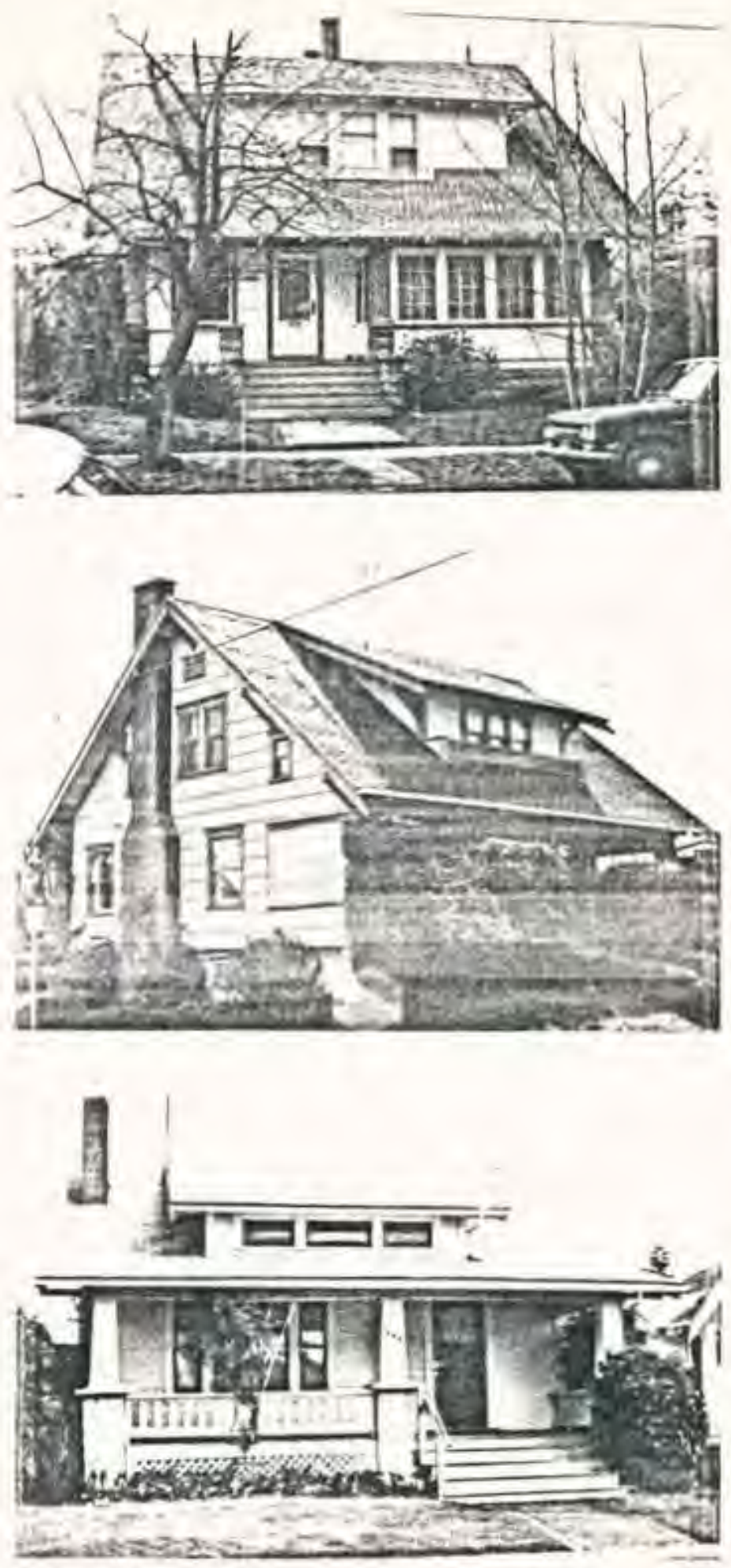

Figure 28. From top: the Sarah Hopfield house, the John G. Baker house, and the C. C. Jacobs house, McMinnville, Oregon. 
Figure 29). The original full-width porch of the Hopfield House has been partially enclosed but the remainder of the plan is intact. There is a living room-dining room area across the front with a kitchen and extra bedroom across the rear. The stairwells in both these houses are tucked away in closed halls. The Jacobs House is far longer from front to rear than the more nearly square Hopfield House, but its floor plan still follows a typical bungalow pattern: living room, dining room, and kitchen along one side and bedrooms and bath along the other.

There are no records of the builders of either the Hopfield House or the Baker House, but Mrs: Baker was a close friend of Dorothy Dielschneider's and Flora Dielschneider, Franz's mother, held the deed to the property for a time while the house was being built. 21 The similarity between the Baker and Dielschneider Houses, added to these associations, suggest that Cook and Arthur might have been the builders of both, Blueprints for the Jacobs House have survived; they bear the name of the designer, Iva G. Lievrance, and the plan number. 22 The Jacobs' daughter remembers that the plans were chosen from a plan book which had either been ordered from a magazine or purchased from the planing mill. Her mother subscribed to both the Ladies'

21Interview with Esther Hamblin DeHaven; Yamhil1 County, Deed Books 63:187; 65:595.

22Iva G. Lievrance, BLUEPRINTS. 


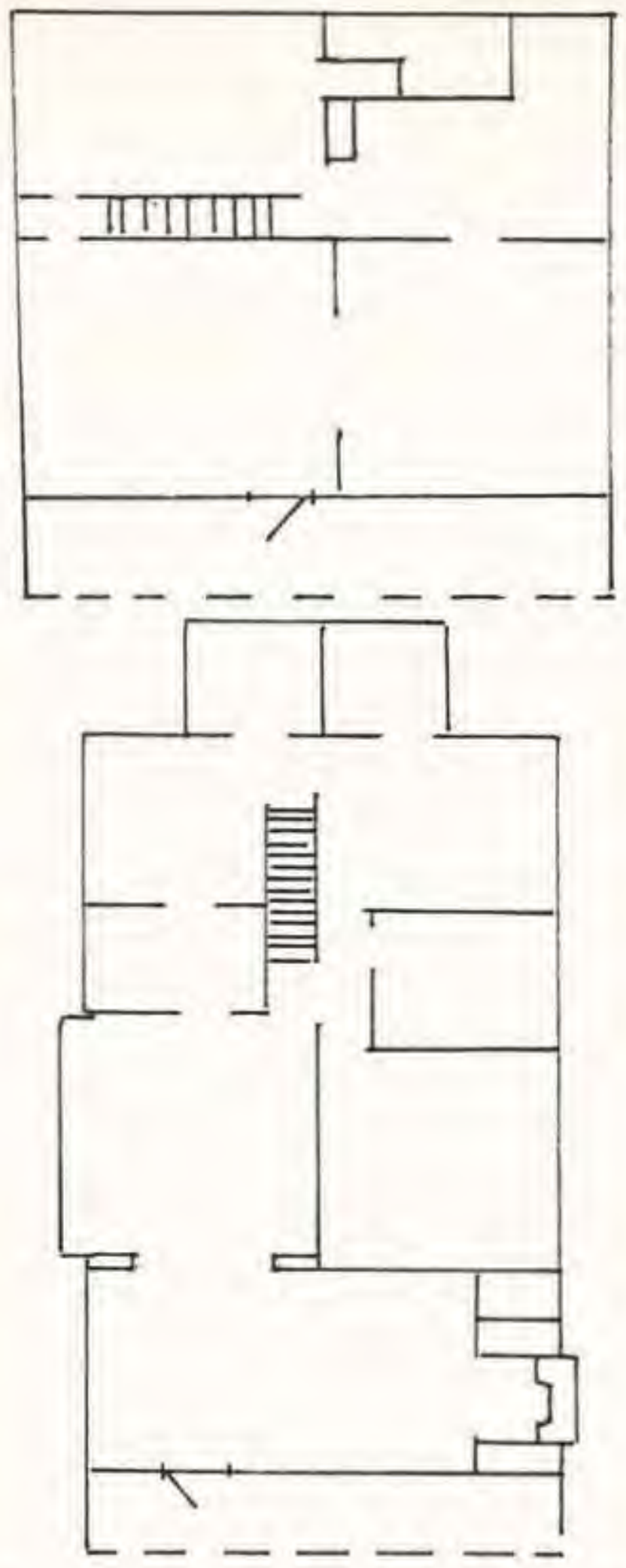

Figure 29. Floor plans of the Sarah Hopfield house, built in 1912, and the C. C. Jacobs house, built in 1921, McMinnville, Oregon 
Home Joumal and McCall's Magazine, 23 No indication of the building company for whom Iva Lievrance worked is given on the blueprints.

None of the people interviewed for this study were associated in any way with either the Baker or the Hopfield Houses, but C. C. Jacobs' daughter was able to recall that her parents chose the plans they did for convenience. They, too, had lived in a tall, two-story, nineteenth-century house prior to building their bungalow; and the storage space, the lower ceilings which conserved heat, and the ample built-in kitchen cabinets were features which attracted them to the new design. 24

All three of these houses had sleeping porches on the second floors. The Jacobs' daughter recalls that the entire family slept there in the summer. So strong was her mother's conviction that sleeping in fresh air was beneficial that they had slept in a backyard tent during the summers they lived in their older house which did not afford a sleeping porch. 25

FOUR ELABORATE HOUSES FROM THE BUNGALOW ERA

Alva D, Hoskins, a hamess and saddle maker, built a rather large and elaborate bungalow-style house in 1981.

23 Aleen Jacobs Fowler, telephone interview, March 22 ,

24 Interview with Aleen Jacobs Fowler.

25 Interview with Aleen Jacobs Fowler. 
McMinnvilie sometime before 1912.26 He bought the property on which the house sits in 1896 but it is difficult to pinpoint the precise building date: 27 The iron fence which stili surrounds the yard bears the date 1910. The plans were drawn by V. L. Derby who, as noted earl1er, practiced the building trade in McMinnville only a short time, and who probably did not have any formal architectural training. (See Figure 30.) The exterior of this house is more complex than any of those examined thus far. It is basically square but the roof is crossgabled on one side, and the porch wraps around one corner. There are profecting, shed-roofed bays on the rear and one side and a large gabled dormer above one offsets the crossgable on the opposite side. There is a second dormer on the rear. The porch piers and foundation are of molded concrete stone, very common in McMinnville bungalows, and the porch ralling is of brick topped by a cement cap. The fron fence mentioned earlier bears the name of Stewart Iron Works from Cinncinnati, a firm which advertised in the Ladies' Home Journal in 1909. 28

The room arrangement of the Hoskins House differs slightly from other houses examined, another indication that Derby probably planned it himself. A small central entry

260regon and Washington State Gazatteer, 1913-1914. p. 301; Polk's Yamhili and Washington Counties Directory. $2: 85$.

27 Yamili County, Deed Book 33:463.

28 'Ladies' Home Journal, April, 1909 , p. 86 

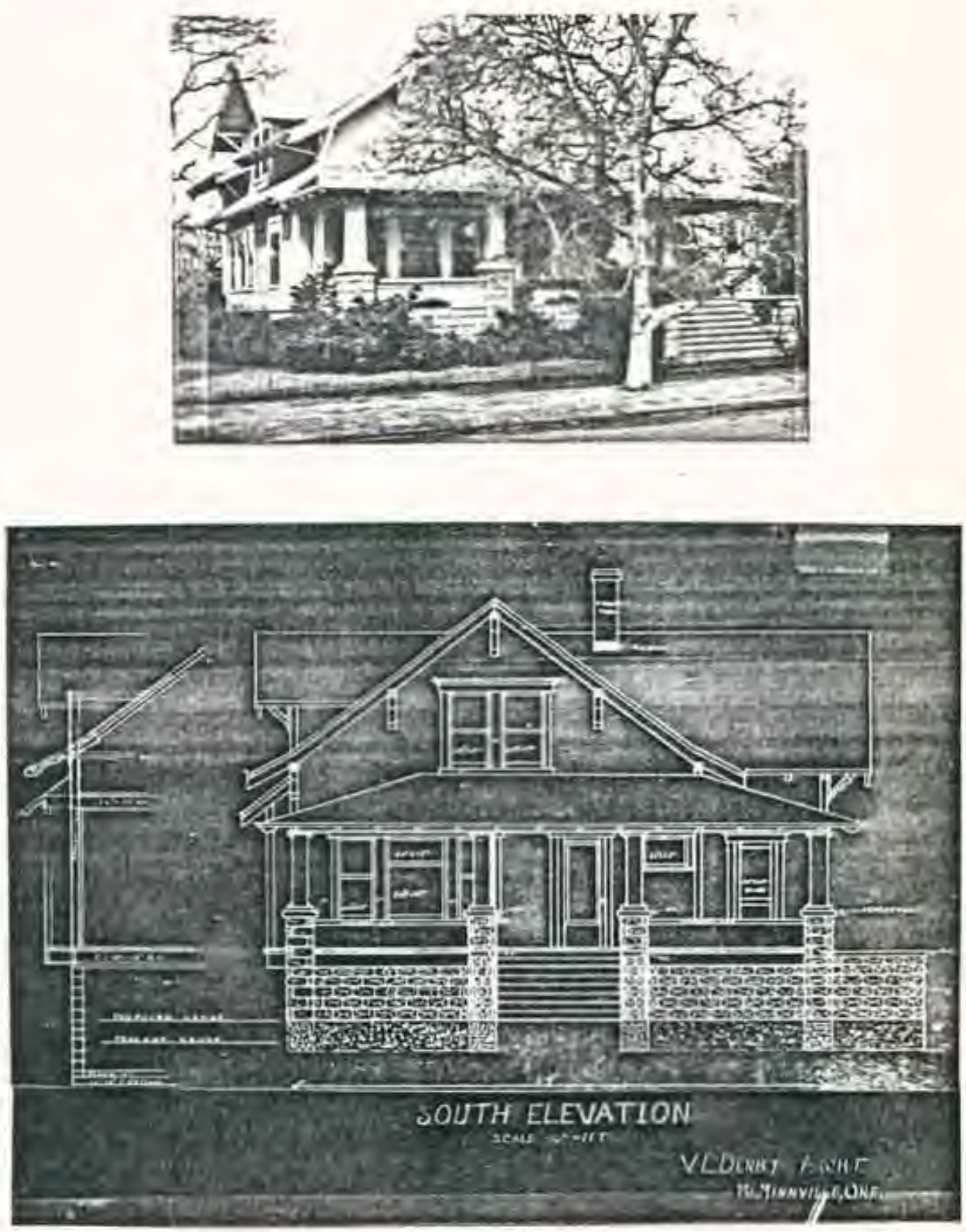

Figure 30. Photograph and first page of blueprints, Alva D. Hoskins house, McMinnville, Oregon. 
houses an open stairway and opens into the sitting room and the dining room. These two rooms are joined by an open arch but the dining room is far larger than the sitting room. A pass-through serving window opens from the dining room to the right into a large kitchen which dominates the opposite side of the house. The rear of the first floor is divided into bedroom, bath and utility porch. The second floor is divided into bedrooms and storage space.

Litcle is known about Alva Hoskins. His ability to build such a large and impressive bungalow-style house may have resulted from the real estate speculating he did. Yamhill County deed records show that he bought and sold property frequently in the early 1900 's. Members of his family still owned the home when it was sold in 1954.29

One of the most elaborate bungalow-style houses still standing in McMinnville is the home built by retized farmer. Lorenzo D. Mulkey in 1914. The Mulkey family had crossed the plains to Oregon in 1848 and according to Joseph Gaston, Lorenzo's widowed grandmother had originally seteled on the site of McMinnville, 30 Her son, Monroe, father of L. D, , had acquired several farms in the area west of McMinnville by the time of his death in 1912. Monroe left an estate of

29 See Yamh111 County, Deed Books, 33:463; 35:264; 274:241; Reverse Index to Deeds, vols, 3 and 4 .

30 Gaston, $\quad 3=397-398$, 
$\$ 21,000$ with a yearly income of $\$ 1,000,31$ Lorenzo D. apparently used part of his share of the inheritance to purchase his fifty-flve by one hundred foot lot in McMinnville From D. E. Wheeler in 1914.32 Between 1915 and 1918, L. D. Mulkey was to invest in over two hundred acres $1 \mathrm{n}$ city and rural properties. 33

According to the Mulkeys' granddaughter who had lived with them in their elegant bungalow in the 1920's, they moved to MeMinnville from a farm where they had lived in an old, two-story house wich a verandah. 34 Although there is no record of what the McMinnville house cost, the Mulkeys spared no expense. (See Figure 31.) The many gables with their curved brackets, the large wrap-around porch with particularly ornamental posts and large cement stone piers, the tall cement stone chimney, and the curved rafters all lend to a richly textured visual display. The interior is no less impressive. The usual living room-dining room space dominates one side of the first floor, but this house, which has a large entry with stairway and inglenook, also boasts a Iibrary which opens out onto the spacious porch via French doors. The dining room with all its magnificent oak woodwork is particularly sumptuous. The room has a massive

3IYamhil1 County, Deed Book 66:306.

32 Ibid., P, 279; Deed Book 67:239.

${ }^{33}$ Yamhill County, Deed Books 68:632; 72:133; 75:114. ${ }^{34}$ Interview with Mary Frances Mulkey Gerber; 

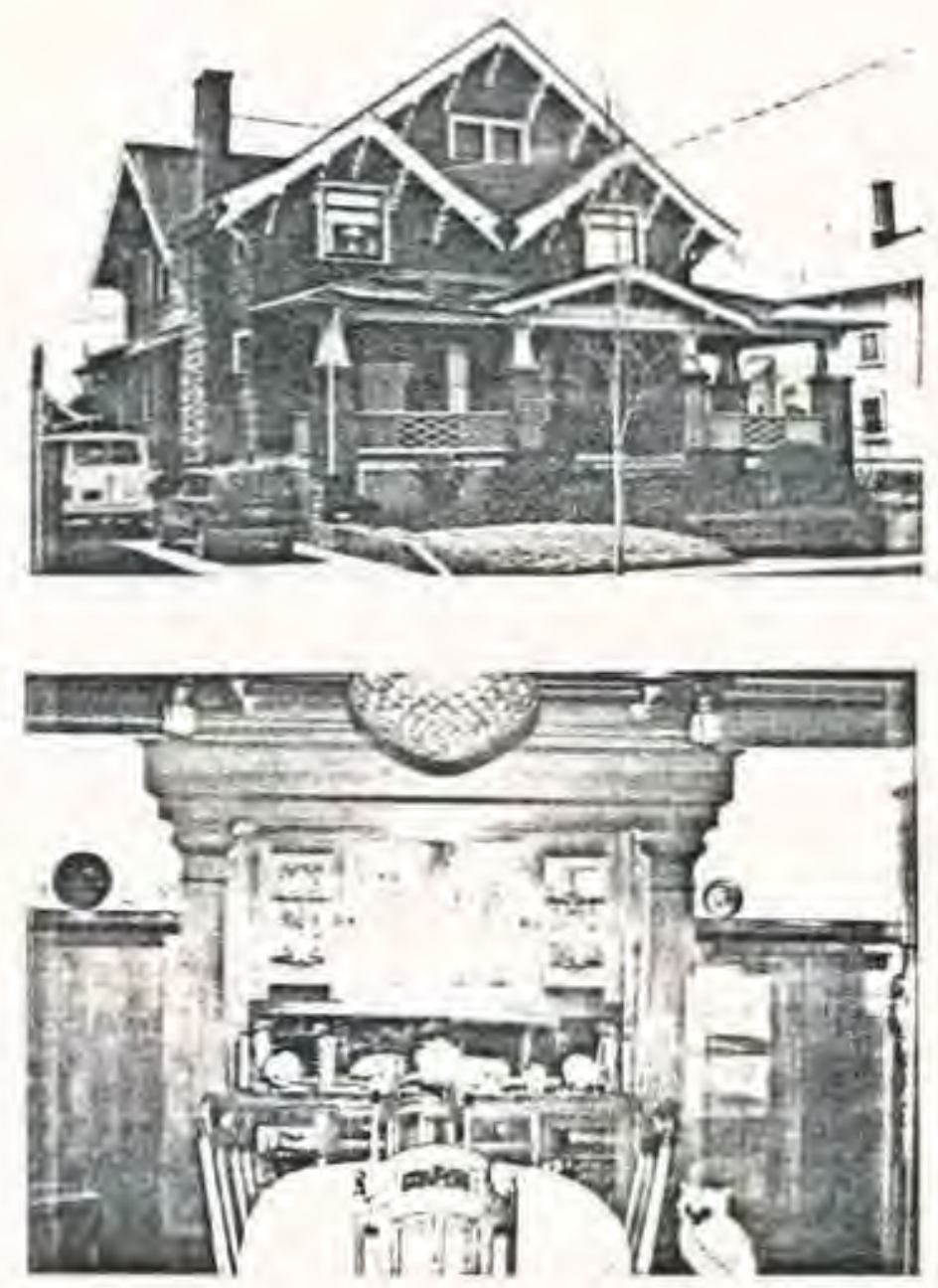

Figure 31, Lorenzo D. Mulkey house, McMinnville, Oregon. Frontal view and interior of the dining room. 
floor-to-celling built-in china cabinet, a long window seat, exposed beams, and a very large leaded-glass light fixcure. (See Figure 31.) Bookcases within an arch define the living room and dining room areas. Their doors are made with etched, leaded-glass panels. The floors are oaken only on the perimeters of the rooms; the centers were laid with unfinished fir to anchor rugs. Eight of the windows in the house are of beveled, leaded-glass panes in different designs; some are geometric, others are stylized floral shapes. A woman who had known the Mulkeys' daughter when both were young recalled that it was the only house in McMinnville at the time to have what she called an "electric chair," an electrically-powered elevator chair on the back stairs. 35

In spite of the luxury, the granddaughter recalled that Mr. Mulkey had been disappointed to discover that the interiors were veneered when he had expected solid oak, 36 A visit to the house confirmed this; the balustrade in the front entry hall was peeling. Nevertheless, the craftsmanship was superior. James Bickford's daughter believed that her brother may have bullt the Mulkey House; she recalled that Mrs. Mulkey had been most pleased with the stairway. 37 The granddaughter had thought the house was probably built from a stock plan and Bickford's daughter recalled that her
35 Interview with Edna Hodson Stanard. 36 Interview with Mary Frances Mulkey Gerber. 37 Interview with Ruth Bickford McCall. 
brother usualiy had plans made in Portland. The details of the house, though more elaborate and costly than others, certainly conform to the contemporary bungalow fashion.

If interviewees' recollections and assumptions drawn from deed records are accurate, the Mulkey house is probably a good example of the result of style promulgation. The neighbors do not recall that the Mulkeys entertained in their new McMinnville home, and the granddaughter believes the house from which they had moved was rather plain. 38 It would appear, then, that they may have built their luxurious home as a response to fashion rather than need.

Walter Link, cashier at McMinnville National Bank and a bachelor who lived with his sister, built a house unique to McMinnville during the bungalow years, for it was the only house investigated to exhibit decided Arts and Crafts influence throughout. 39 The house is a stucco rectangle with a tiled hip roof lifted and expanded by four large gabled dormers, one on each side. The large brick exterior chimney dominates one side of the facade and a cutaway glassed-in porch reaches across the other. The brick foundation is laid in an unusual vertical bond. A pergola built on piers of varying heights shelters the brick front

38Interviews with Lauretta and Marguerite Wheeler; Mary Frances Mulkey Gerber.

${ }^{39} \mathrm{C} 1$ ark, 3:571-572. 
walk. A brick design is laid even in the portion of the public walk which passes in front of the house. (See Figure 32, )

This delightful attention to detail is repeated in the interior. The floor plan is familfar; living room, dining room, and kitchen occupy one side. But this house, like the Mulkeys', has an extra room. The cutaway porch leads into a large stair entry and the entry leads through a telephone hall into a large, leather-paneled den. The paneling, studded with brass nallheads and framed with dark wood, rises nearly seven feet from the floor. The ceiling is crisscrossed by exposed beams and built-in cabinetry surrounds a window at one end. Serving access from the kitchen is provided through a sliding stained-glass window of Arts and Crafts design. Another Arts and Crafts feature is the fireplace inglenook which occupies the front end of the living room. Like examples from The Craftsman, the fulllength tiled fireplace is graced by a hammered, copper hood which bears a homely verse:

Stay, stay at home my heart And rest

Homekeeping hearts are happiest

For those that wander they Know not where

Are full of trouble and full of care, To stay at home is best.

(See Figures 32 and 33. )

The Iiving room and dining room are separated by a bracketed arch and both are wainscoted. The kitchen is unusually small but very efficient and compact, completely furnished with 

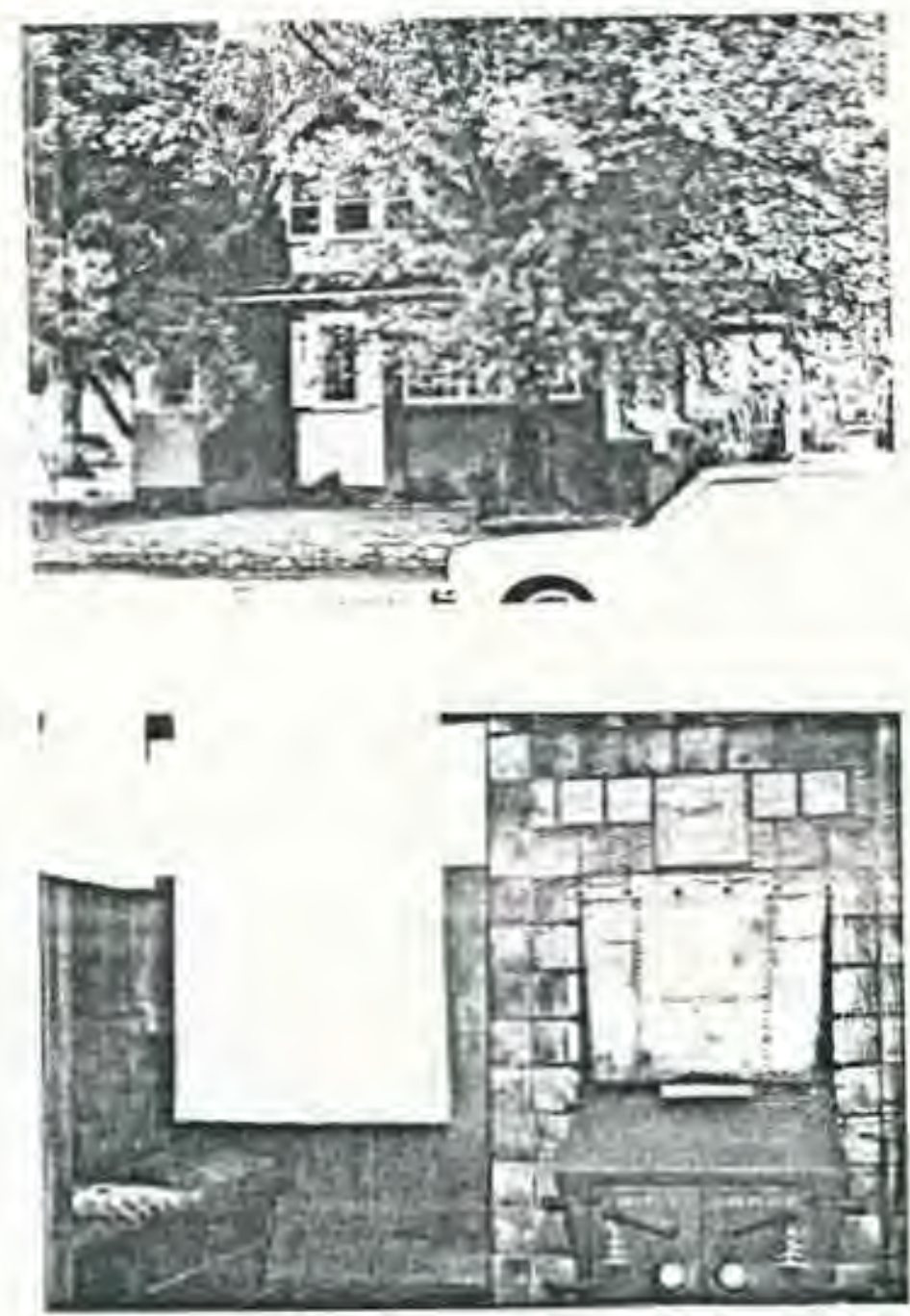

Figure 32. Walter Links house, MoMinnville, Oregon. Frontal view and interior view showing fireplace and inglenook. 


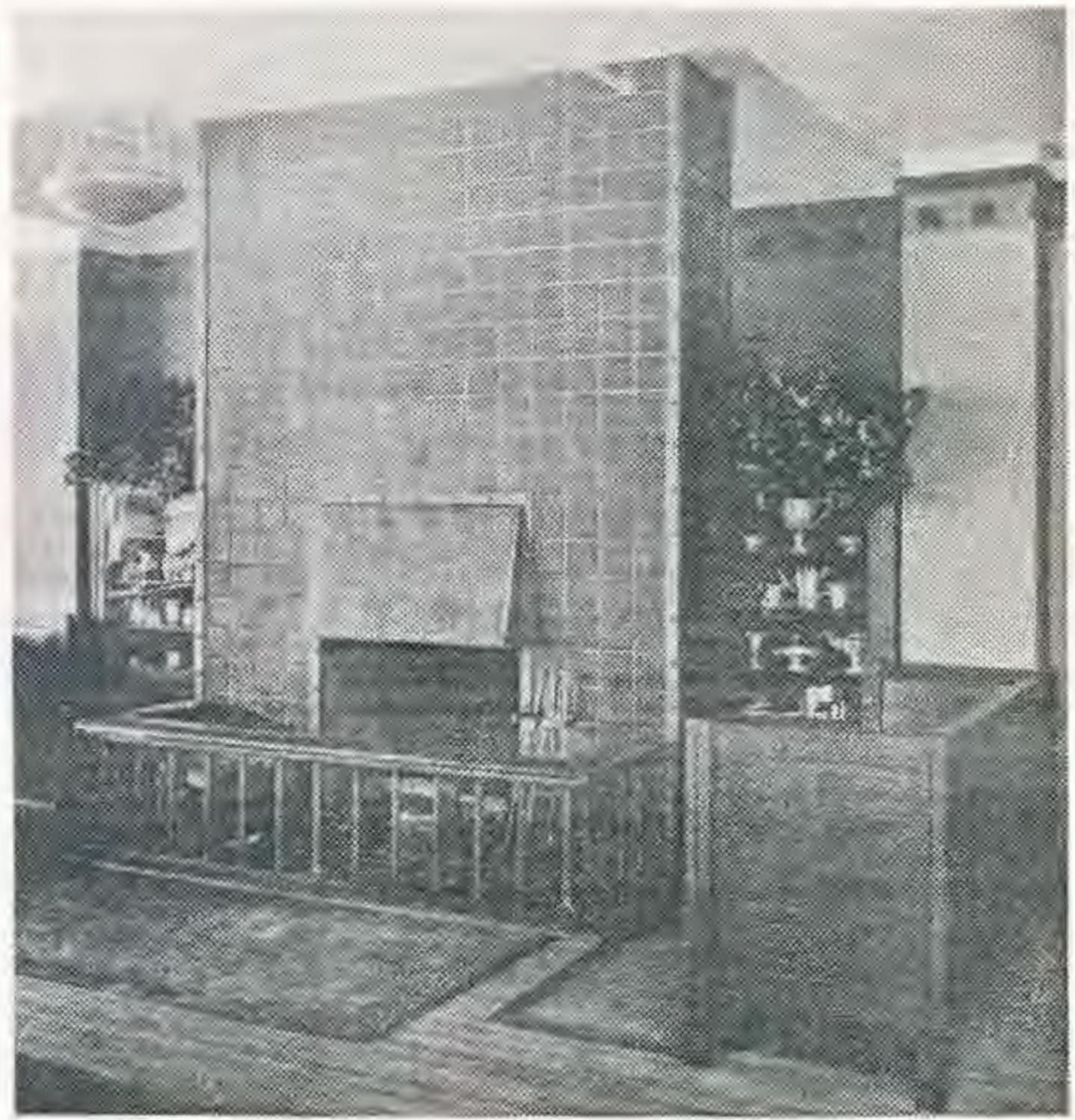

Figure 33. Chimneypiece in the Craftsman Restaurant, Tew York. Frotn The Craftsman, January, 1914, p. 363. 
floor-to-ceiling built-in cabinetry. A completely tiled bath resembles advertisements found in magazines of the period.

Although the Link House is not truly a bungalow-style house, it has been included in this study because the abvious Arts and Crafts influence lends credence to the thesis that magazine and plan book promulgation had its effect in McMinnvilie. It also reflects, more than any other house examined, the breadth of the Arts and Crafts Movement.

A newspaper item from 1910 announced that Walter and Alice Link moved into their new domicile at this address, but the abstract of title for the property shows that Link bought it in 1915 for $\$ 1,200,40$ This suggests that a house stood upon the lot at the time of the purchase and that he either rebulit or remodelled, for his Arts and Crafts house would surely have commanded more than $\$ 1,000$ in 1915. Link was obviously comfortable enough financially to afford the exquisite details and fine craftsmanship in his new house. Besides his position as director and cashier at the bank, be was an investor. Between 1904 and 1912, he bought a considerable amount of valuable city property. 41 By 1927 he owned a farm where he raised purebred Hampshire sheep. He was prominent in civic affairs; he had served as a member of

${ }^{40}$ The Telephone Register, March 11, 1910, P. S; Yamhill County Abstract Company, "Abstract of Title, No. 665," TYPESCRIPT (McMinnville, Oregon, 1950), P. 18. $63: 497$,

41Yamhil1 County, Deed Books 46:54: 53:82, 159; 
the Water and Light Commission, and belonged to the Chamber of Commerce, 42 Walter Link's house is the only evidence that he was conversant with the Arts and Crafts Movement, but that evidence is incontrovertible.

The latest bungalow-style house this study will treat was built in 1922 by James H. Gibson, owner of Yamhi11 County Abstract Company, 43 This house is a Iarge sprawling, multigabled horizontal structure which resembles, more than any other McMinnville bungalow, some of the designs of Charles and Henry Greene. (See Figures 34 and 35.) The plan for it was ordered from a Spokane firm, The National Builders Bureau. 44 The Gibson House exhibits niceties in craftsmanship and materials that other McMinnville houses lack. The roughcut stone foundation and porch piers are genuine. The exterior chimney, so dominant on one side, bristles with clinker brick. River rock aggregate lends texture to the area under the broad gable which shelters the entrance. The heavy oaken woodwork, so plentiful throughout the interior, is beautifully crafted. The Gibsons' daughter, who still occupies the house, recalled that the wood was imported from

42 Clark, 3:571-572.

43 Interview with Evelyn Gibson DeGordin; Julia Etta Cummins Gibson, "Cummins Family History," TYPESCRIPT (McMinnville, 1954), p. 16.

44 National Builders Bureau, BLUEPRINTS (Spokane, Washington, n. d.). The National Builders Bureau was listed in Spokane in the Oregon and Washington State Gazatteer from 1919 (p. 673) until 1926 (p. 911). 


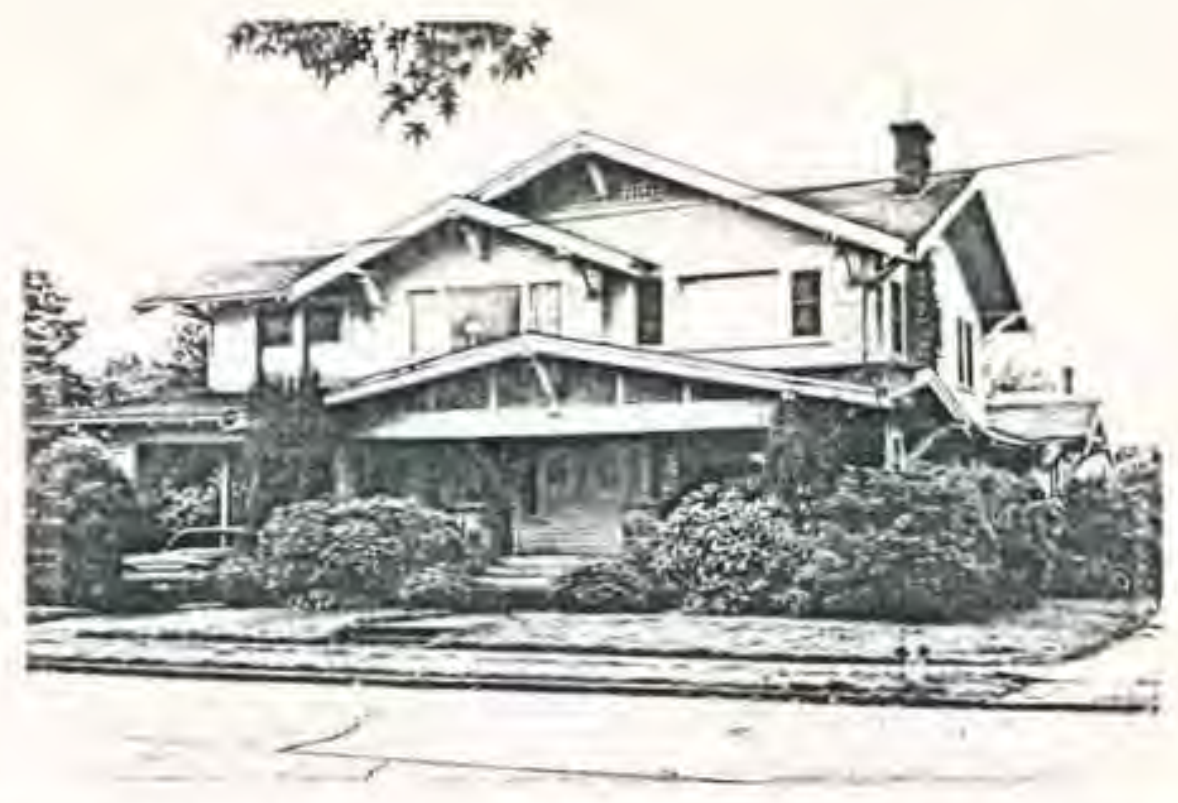

Figure 34. The James H. Gibson House, McMinnville, oregon.

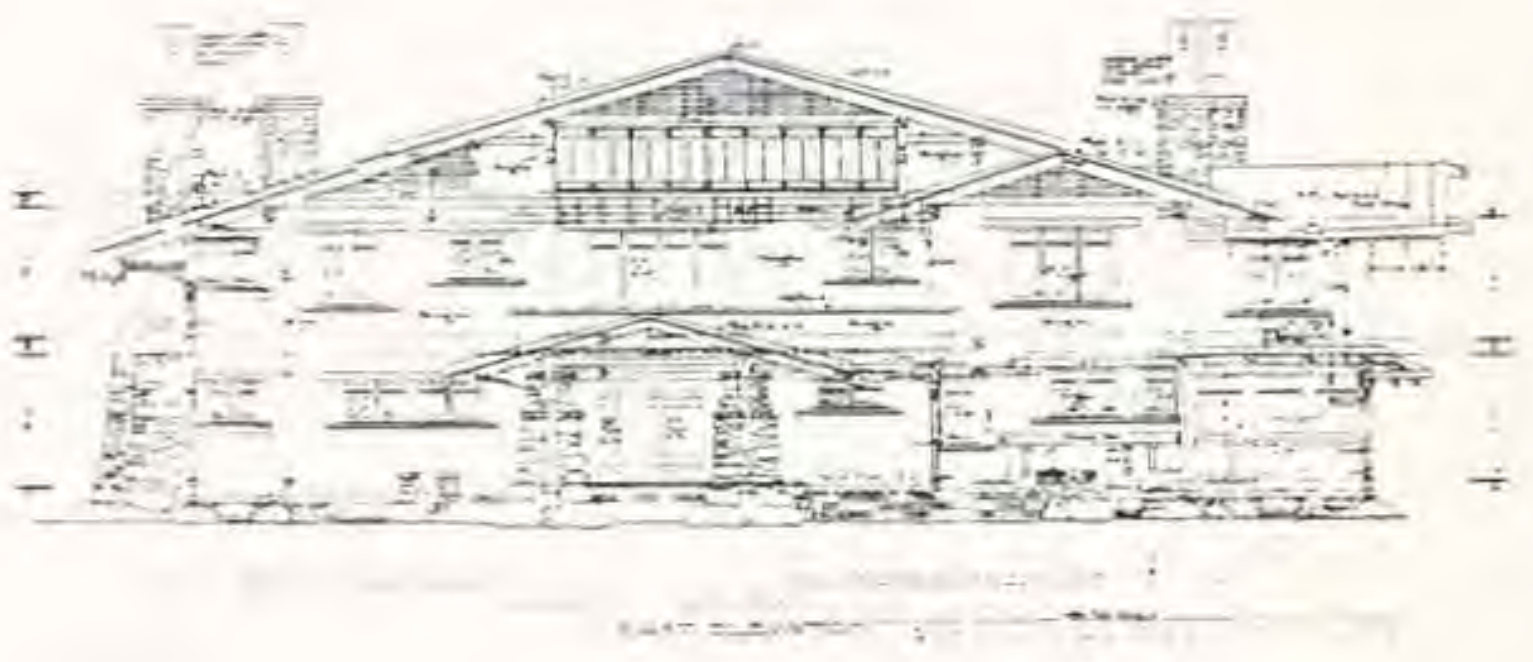

Figure 35. Greene and Greene drawing of the Mary Cole House from Current and Current, p. 24. Avery Architectural and Fine Arts Library collection, Columbia University. 
the East. 45 The floor plan is open and the house has a full basement. Like many other bungalow-style houses in McMinnville, the Gibson House is equipped with a sleeping porch,

James Gibson was a native Oregonian who had studied law at the University of Oregon. He moved to McMinnville in 1906 and operated the abstract company for forty years. 46 He served on the City Council and belonged to several lodges. In 1911 the family had bought a tall, two-story house with vague Italianate features. 47 By 1922 circumstances were such that they wanted a new home, so the old house was moved to an adjolning lot and the bungalow was bullt. Gibsons' daughter remembers that her mother wanted a colonial house, but her father's preference for the new style prevailed because he did not want a traditional, central hall and he wanted the view which the newer, wider windows afforded. 48 This recollection suggests a change in the way Mr. Gibson viewed his home. The daughter recalls that her mother, on the other hand, although she read women's magazines--the Ladies' Home Journal in particular--resisted innovations.

45 Interview with Evelyn Gibson DeGordin.

46 Julia Ecta Cummins Gibson, "The Gibson Family," TYPESCRIPT (McMinnvilie, Oregon, 1954), p. 4.

${ }^{47}$ Photograph, Evelyn Gibson DeGordin Collection, McMinnville, Oregon.

48Interview with Evelyn Gibson DeGordin. 
It was her husband who introduced the conveniences of modern living. 49

THREE MCMINNVILLE HOUSES IDENTIFIED IN PLAN BOOKS

A 1909 issue of the Telephone Register carried the following item:

Dr. J. H. Cook was issued a permit this week for a one and a half story bungalo $37 \frac{1}{2}$ X 55 feet on lot 8, block 3, of the College Addition. It will probably cost $\$ 4,000,50$

Figure 36 shows Dr. Cook's house in McMinnville and below it, a picture from Henry Fancher's Craftsman Book of Bungalows, second edition. The house was described as "the better class of Bungalow, very popular and increasing in favor." The horizontal lines, wrote the book's author, emphasized "the Bungalow feeling of hospitality and restful home."5I The plan book did not give the cost for building this house, but Dr. Cook's estimate is commensurate with the size and level of detall; the house is considerably more luxurious than those costing $\$ 1,500$ or $\$ 1,600$ as 1 ate as 1915 . It is multi-gabled with bays, porches, and dormers. The shingle siding was originally dark brown and the yard was once encircled by maple trees. The building which now serves as a garage was erected at the same time the house was, but

${ }^{49}$ Interview with Evelyn Gibson DeGordin, 50 The Telephone Register, July 2, 1909, P. 6. 51 The Craftsman Book of Bungalows, p. 67. 

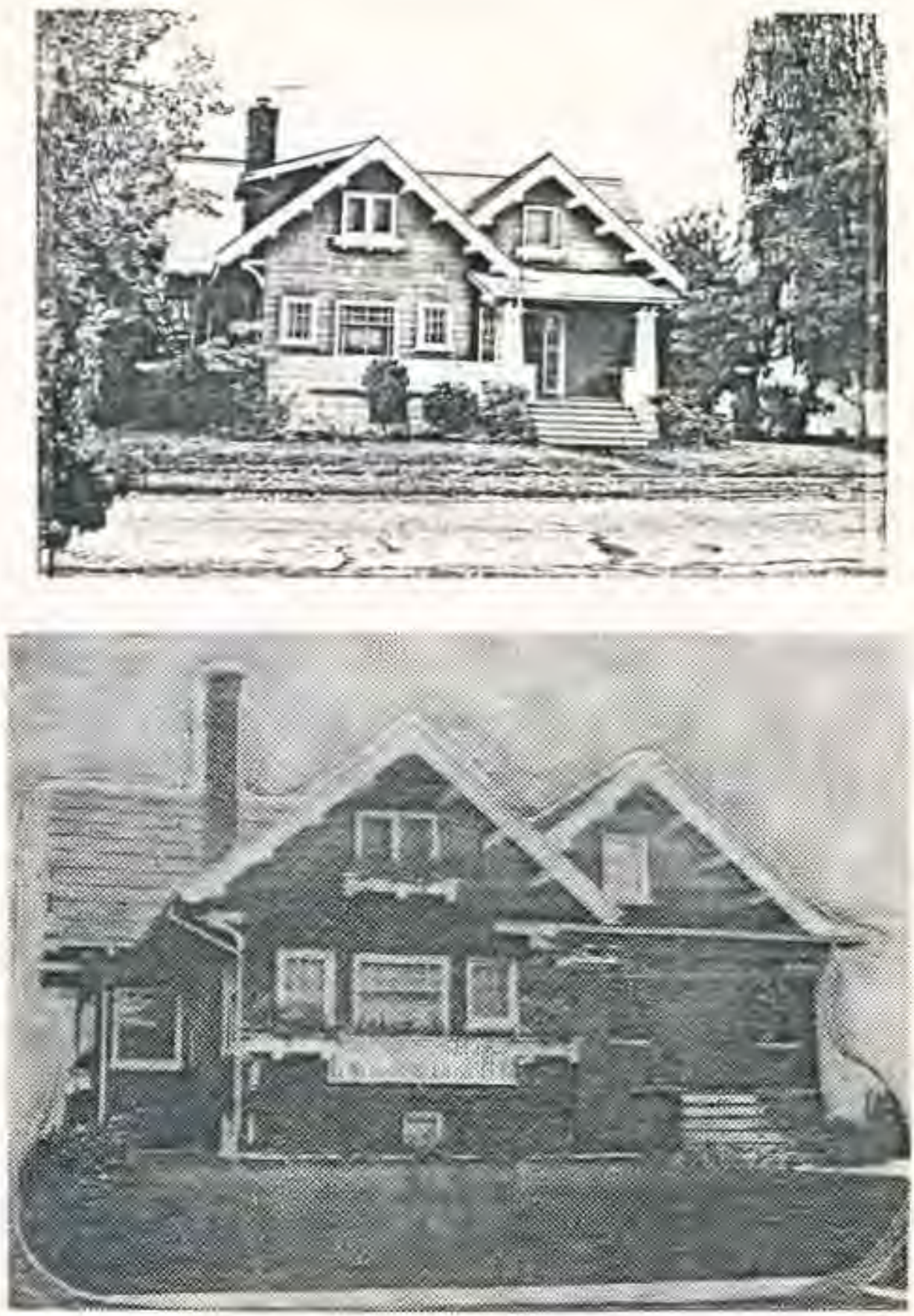

Figure 36. James H. Cook Rouse, MoMinnville, Oregon and photograph from Craftsman Book of Bungalows, D, 67. 
served as a stable unt1l 1910 when $\mathrm{Dr}$. Cook bought his first automobile, 52

The interior of the Cook House reveals the vestiges of traditional room arrangement: a large kitchen devoid of builc-ins, a pantry, and sliding doors between the living and dining rooms. But some of the hallmarks of the bungalow aesthetic were incorporated. There was no parlor, the back rooms opened off an enclosed hall, and the second floor accommodated a sleeping porch. The dining room was lined with wainscoting and platerail, and the living room fireplace was originally of white tiles. The Brussels carpet which covered the entry, living room, and dining room was replaced with hardwood floors at some later date. 53

Dr. James Cook was born near McMinnville and his wife had come to Oregon from Chicago. 54 He was a popular and congenial physician who enjoyed a large practice, a man who wielded influence and displayed concern for his town. 55 He served as county health officer, city physician, and medical atcendant for Woodmen of the World and Women of Woodcraft, 56

52 Interview with Willetta Leever Dow.

53 Interview with Willetta Leever Dow.

54 Interview with Willetta Leever Dow.

55 Interviews with Willetta Leever Dow, Evelyn Gibson DeGordin, Floyd Odel1; The Telephone Register, May 22, 1903, p. 5 .

56Polk's Yamhill and Washington Counties Directory, 2:71; McMinnville City Council, "Minute Book 6," April I, 1902, P. 139; The Telephone Register, January 10, 1908, p. 1. 
The Cooks owned the entire block upon which their house stood, and the doctor subdivided it and built rental houses in later years. He also owned prune and walnut orchards outside the city, 57

In 1919 the Cooks, childless themselves, took in two girls who had been orphaned by the deach of a widowed mother. One of the girls, eleven years old at the time of her mother's death, recalled many details of the Cook's life in their bungalow. She remembered that Mrs. Cook had told ker they chose the style from a house they had seen in Portland. This suggests they chose the plan not from Fancher's plan book but from the house pictured in the plan book. She recalled that the living room had been used for family evenings together and that they slept on the sleeping porch in the summers. Mrs. Cook, she said, had many friends and both she and her husband participated in local organizations. A Telephone

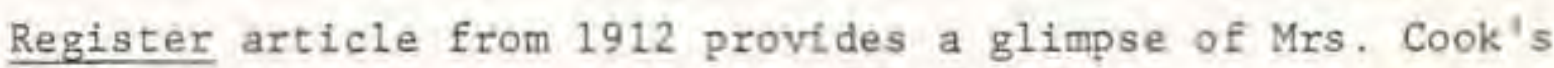
entertaining. Forty members of the Shakespeare Club, it was reported, attended a Washington's Birthday Party Iuncheon at her home. Carnations and violets adomed the rooms and music and Shakespeare readings provided entertainment. 58

The Cooks, like so many other bungalow owners, had lived in an 1890's Queen Anne style home before building

57 Interview with Willetta Leever Dow. ${ }^{58}$ The Telephone Register, March 1, 1912, p. 6. 
their Fancher house. They were considered well-to-do and enjoyed status. Their bungalow was thought a fine home and admired for its grandness, 59 Recollections of their life in it suggest that they enjoyed its amblence, but there was no Indication that their choice of it signified anything more than a desire to have a new home, one which pleased them visually and conformed to the fashion of the day.

Another Fancher design identified in McMinnville is a vertical house with bungalow ornament: dormer, upturned eaves, brackets, and exposed rafters. The plan book claimed that the "prevailing influence of architecture (in the house) is the English Pointed and the Swiss Chalet." The house could be built for $\$ 1,800$ "with double construction and full cement basement."60 TheMcMinnville example of this design differed originally only on the exterior where the porch was shortened; the interior plan was identical. (See Figure 37.) In later years, a carport and rear rooms were added but the Fancher design remains identifiable. The interior Finish is consistent with bungalow design. The dining room is wainscoted and exposed beams crisscross its ceiling. The brown brick comer fireplace in the living room is superImposed by a mantel which matches the dining room woodwork. The first floor 1s laid with hardwood floors. The house was

59 Interviews with Willetta Leever Dow; Floyd Odell; Evelyn Gibson DeGordin.

60 The Craftsman Book of Bungalows, p. 81 

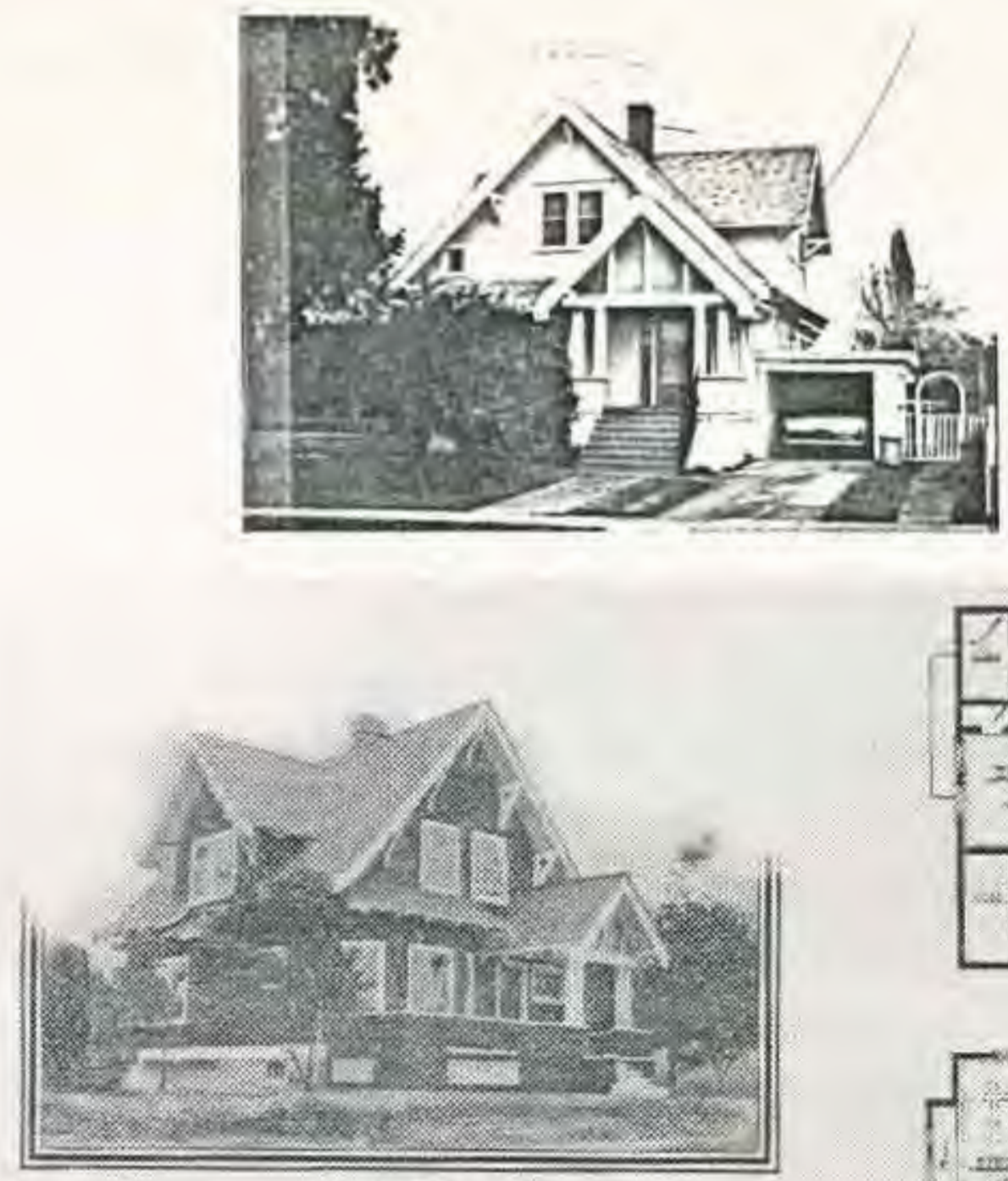

PLNN XO. 81

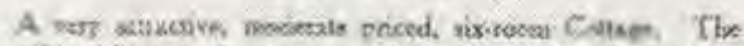

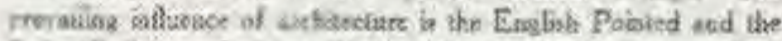

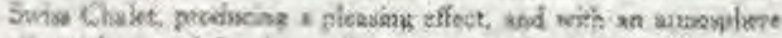

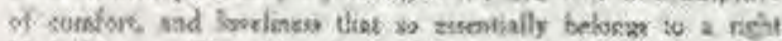

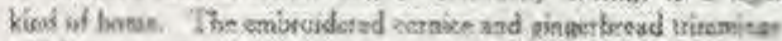

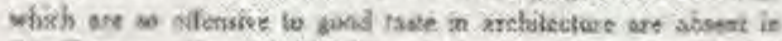

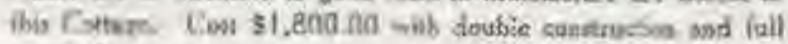
cecment bsismeat.

Set of blaw 510.00
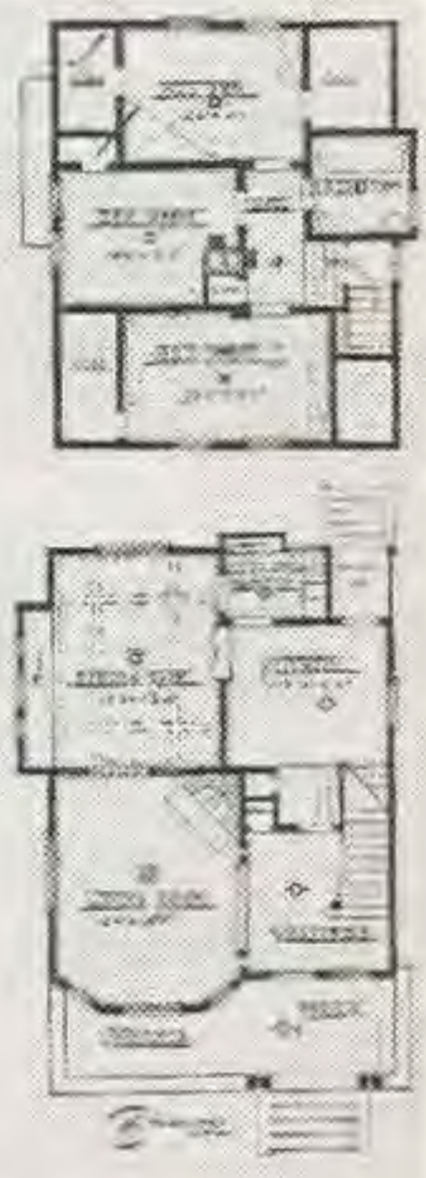

Figure 37. The T. E. O'Neill House, McMinnville, Oregon and a photograph and plan from The Craftsman Book of Bungalows, p. 41. 
probably built between 1911 and $1919--t h e$ same period during which The Craftsman Book of Bungalows was printed--by T. E. 0'Neil1 who owned the lot on which it stands from 1911 until 1936. 61

The owners of this house, 1fke many who have 11 ved in bungalows up to the present time, have made no changes in the interior floor plan; their only substantial alteration was the rear addition, bullt to afford more space for a family. This reluctance to change the original design of the living area suggests that the basic bungalow floor plan was workable and adaptable. Yet the owners' recollections of their reasons for choosing to buy this house in $1936 \mathrm{did}$ not include analysis of space arrangement. They remembered being attracted by the exterior appearance, the hardwood floors, the open stairs, and the fireplace. 62

The design of the large, two-story, bungalow-style house built by clothing merchant. Delmer E. Wheeler in 1911 appears in the 1908 Radford publication, Artistic Bungalows. 63 (See Figures 38 and 39,) The house was erected by McMinnville contractors Cook and Arthur who also built the Dielschneider House (Figure 26). At the time they contracted

61 Title and Trust Company, "Abstract of Title, no. 4954," TYPESCRIPT (Portland, Oregon, 1950).

$62 \mathrm{H}$. William Odell and Madeline Odell, interyiew. McMinnvilie, Oregon, February 18, I981.

63 Radford's Artistic Bungalows, $\mathrm{p}, 58$; The Telephone Register, June 23, 1911, P. 5. 


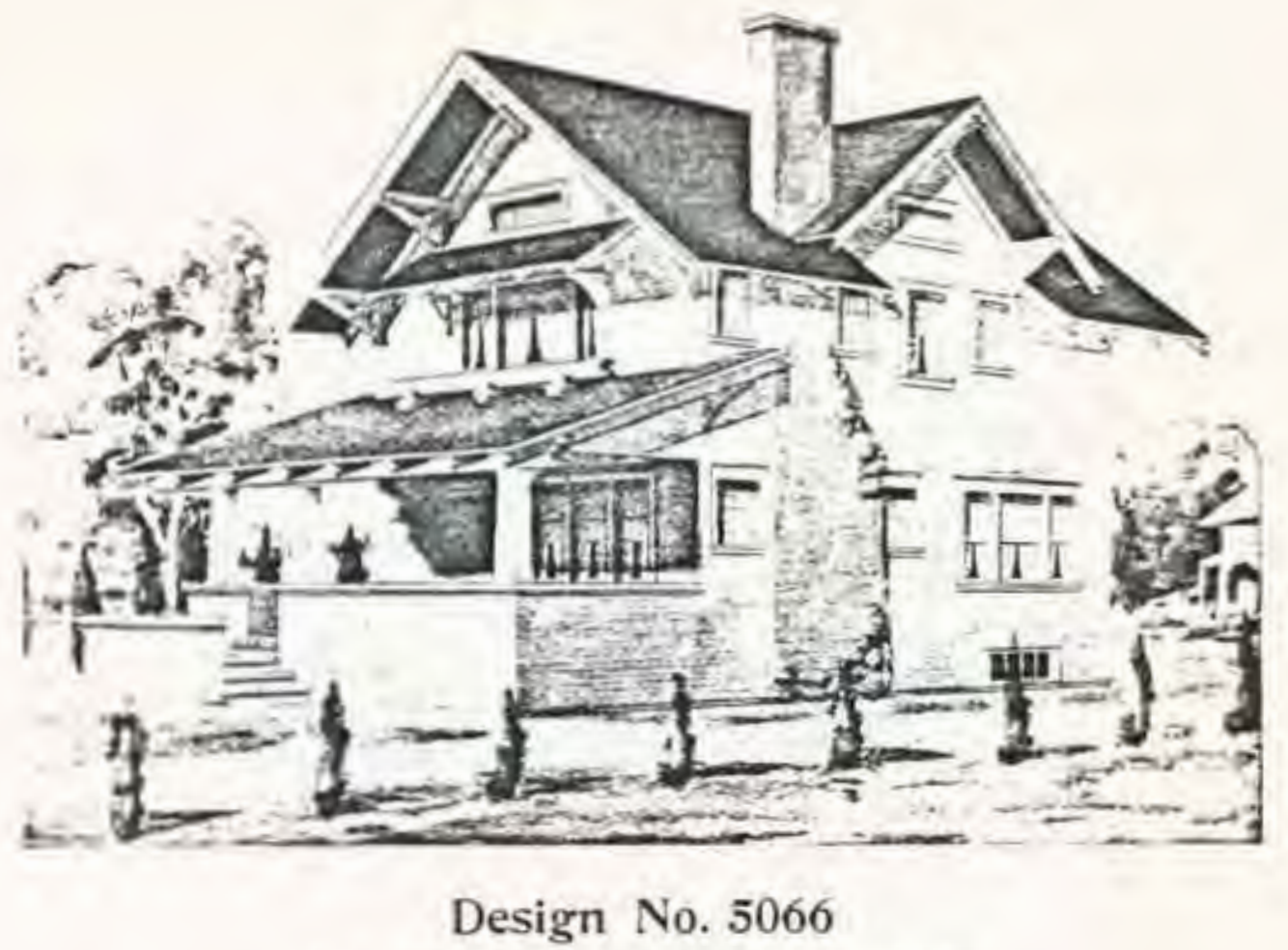

Side: Wideh on feet 6 inches: Length, ga fert 6 inches

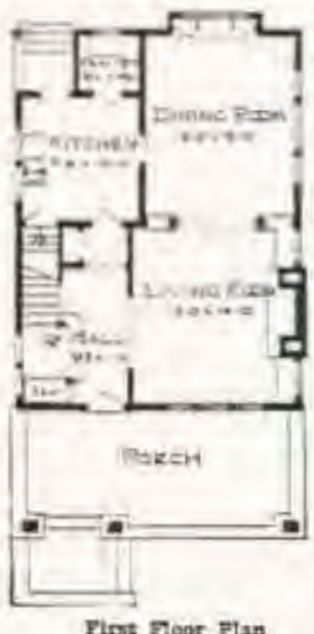

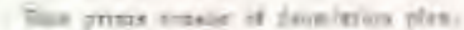

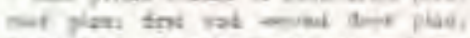

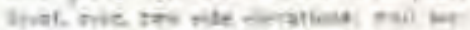

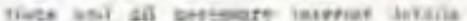

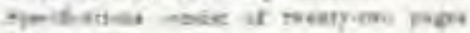
of imewritra matist

\section{FETCE}

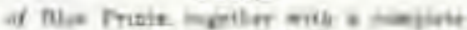

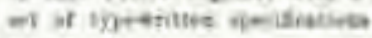

ONzT

\section{$\$ 15: 00$}

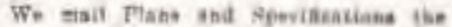
sarse lay anife 4 rewired.

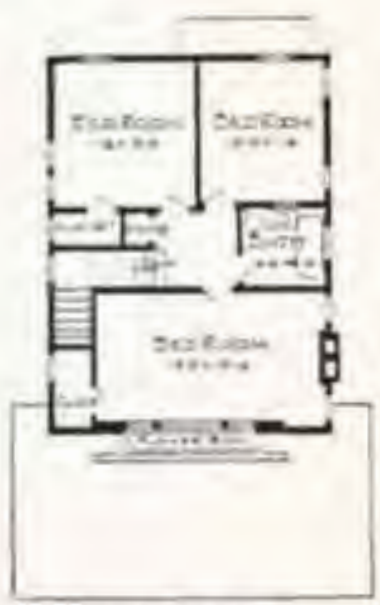

sacsed Thar Tha

Figure 38. House plan from Radford's Artistic Bungalows, p, 58 . 

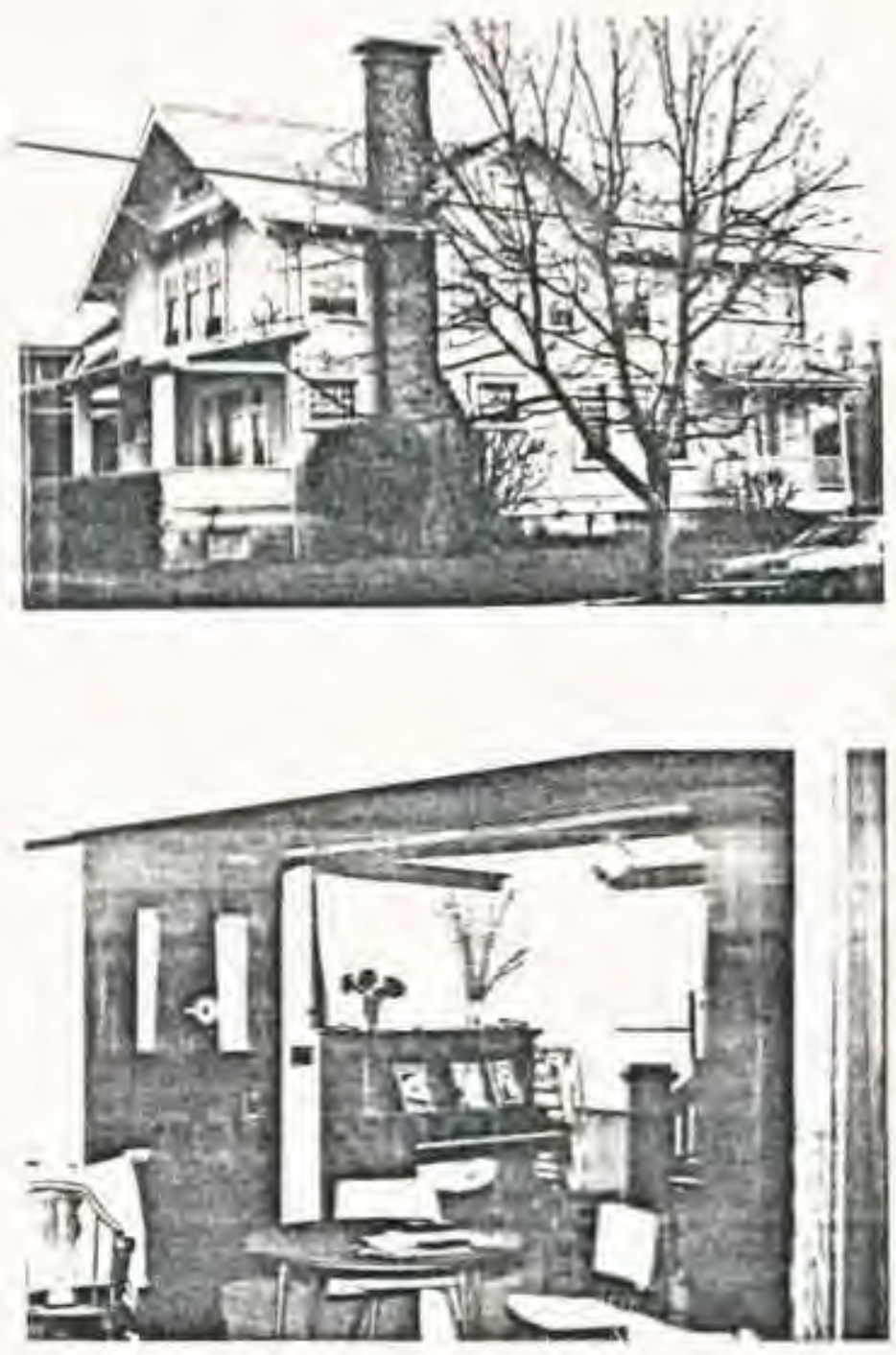

Figure 39. The Delmer Wheeler House, MeMinnville, Oregon. 
to build the Wheeler House, they were also commissioned to build a neighboring house in the dormered box style. Both these houses were reported to cost $\$ 3,500.64$ Radford's Artistic Bungalows estimated the cost of their design to be between $\$ 2,150$ and $\$ 2,300$ in 1908 , but the Wheelers actually built a larger house, adding a sleeping porch and den in the rear. 65 Cook and Arthur, in constructing the Wheeler House. followed the Radford plan on the ground floor, but varied the second story floor plan with four bedrooms instead of three, one opening onto a sleeping porch. Like most of the bungalows examined, the Wheeler House had a full basement which housed a furnace and a woodlift to the kitchen, still operational.

Delmer Wheeler was born in Illinois, fourneyed West in 1888 and had settled in McMinnville by 1902 when he bought an interest in C, R. Hamblin's elothing store. 66 Hamblin-Wheeler was incorporated in 1906 with a capital stock of $\$ 20,000,67$ The business still thrives. Wheeler married Lauretta Redmond in 1906 and Joseph Gaston wrote of them in 1912 that they were "well known socially in

64 Ibid.

65 Radford's Artistic Bungalows, p. 220; interviews with Lauretta and Marguerite Wheeler.

66 Gaston, 2:663.

67 The Telephone Register, January 20, 1906, p. 6. 
MoMinnville and their own home is justly celebrated for its warm-hearted and gracious hospitality. "68

Delmer and Lauretta Wheelers' daughters still live in their parents' house and they recalled that their father not only made the decisions when planning the home; but he also did much of the work himself. The family used the living room-dining room area but the youngsters played in the back den. The sisters recalled that only the children slept on the second floor sleeping porch. 69 A newspaper item reveals the sort of entertainment the Wheelers" "justly celebrated" home afforded. Mrs. Wheeler served a four-course luncheon in flower-bedecked rooms to eighteen members of the Sacajawea Club in 1912,70

These three rather substantial homes taken from commercial plan book designs are but examples. In spite of the fact that only a small number of the houses examined for this study were identified in specific plan books, the evidence suggests that many of them were the products of such books. Many McMinnville bungalows are remarkably similar, plan books were plentiful, and builders used them widely.

${ }^{68}$ Gaston, 2:663.

${ }^{69}$ Interviews with Lauretta and Marguerite Wheeler, 70 The Telephone Register. May 17, 1912, p: 6. 
BUNGALOW DESIGN APPLIED TO OLDER HOUSES

One of the indications that the bungalow style was universally favored is the speed with which the owners of older homes applied bungalow features to their Queen Anne or Italianate houses. Many McMinnville vintage structures were decked with bungalow porches, eaves, and rafters in the early 1900 's.

In 1897, E. C, and Alves Apperson built in McMinnville, a lovely turreted home with a vaguely Queen Anne flavor. 71 The Appersons were very prominent in McMinnville. He had become president of the McMinnville National Bank by 1908 and served as Cicy Treasurer for thirty-five years. 72 Alves Norwood, who had come to Oregon with her family in a boxcar from North Carolina, married Apperson in 1894 and became one of McMinnville's leading citizens. She was active in her church and in the Red Cross; she helped found both the Civic Improvement and the Shakespeare Clubs; and she was a major force behind urging the City to seek a Carnegie grant for McMinnville's library. ${ }^{73}$ The list of organizations to which both she and Mr. Apperson belonged is lengthy and impressive. Mrs. Apperson is remembered as a stylish woman with a strong personality. She was

71 Interview with Letha Apperson; photograph, Letha Apperson Collection, McMinnvilie, Oregon.

${ }^{72}$ Clark, 3:246-249.

73 Ibid., pp. 249-250; interview with Letha Apperson. 
concerned with civic affairs, and socially aware, She was also the only person in McMinnville to have had a uniformed maid, according to the recollections of the people interviewed, 74 Alves Apperson was one of the few women to merit a biographical sketch of her own in Clark's History of the Willamette Va11ey. 75

In 1909, when their house was only twelve years old, the Appersons remodelled extensively, changing its appearance entirely. (See Figure 40.) Although the renovated version cannot be called a bungalow, certain features were obviously influenced by bungalow design. The new eaves were wide and upturned, structure was expressed, and the large porch was given square, sturdy posts. The interior alterations made at the same time were especially typical of the bungalow aesthetic. The two parlors were opened into one space, a sleeping porch was incorporated into the second floor plan and the dining room was finished in oak and furnished with a massive built-in china closet. (See Figure 40.) The alterations to the dining room reflect Arts and Crafts influence; the window and china closet surrounds have projecting, crisscrossed corners, hammered brass nailheads stud the woodwork, and a hammered brass and oak light fixture hangs from the ceiling.

74 Interviews with Letha Apperson; Dorothy Wortman Gunness; Willetta Leever Dow; Edna Hodson Stanard.

75 Clark, 3:249-250, 

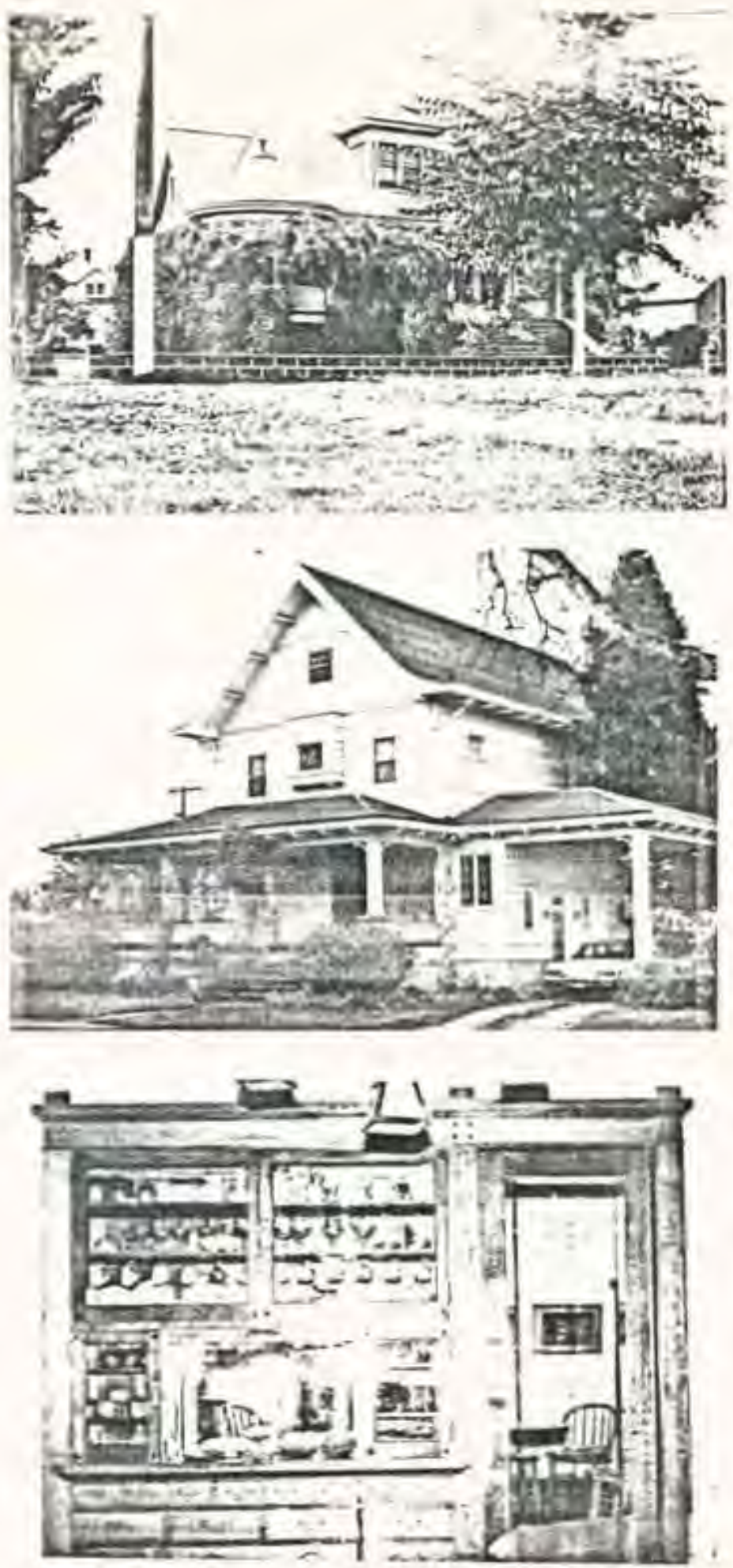

Figure 40. From the top: the E. C. Apperson House, McMinnvilie, Oregon when new in 1897, after alterations in 1909, and interior. 
Apperson was a Republican, his professional pursuits lent support to the Capitalist system, and his wife's life style exhibited acceptance of social distinctions.76 For these reasons, it is impossible to attribute their 1909 flirtation with the Arts and Crafts Movement to any philosophical kinship to Morris' socialist ideas about a brotherhood of artists or to Stickley's socialism of art. The desire to have a home which displayed the latest fashion seems a more creditable explanation for the changes.

The two houses pictured in Figure 41 illustrate the popularity of the bungalow-inspired porch. The first house shown is the Italianate-style house of Thomas Turner built in 1883. An earlier porch was a diminutive one supported by slender columns and sawn wood brackets, 77 The large porch with the square bungalow-style posts was added in 1917.78

The Eastlake-style Queen Anne house pictured in Figure 41 was the home of prominent McMinnville merchant, 0.0 . Hodson whose daughter still occupies the house. It was already several years old when Hodson moved into it in 1899.79 An item appeared in a 1910 issue of The Telephone

76 clark, 3:246-249.

77 Photograph, Collection of June Druse, McMinnville, Oregon.

78"McMinnville Historic Resource Inventory," 1:46,

79 Interview with Edna Hodson Stanard; Polk's Yamhi11 and Washington Counties Directory, 2:84. 

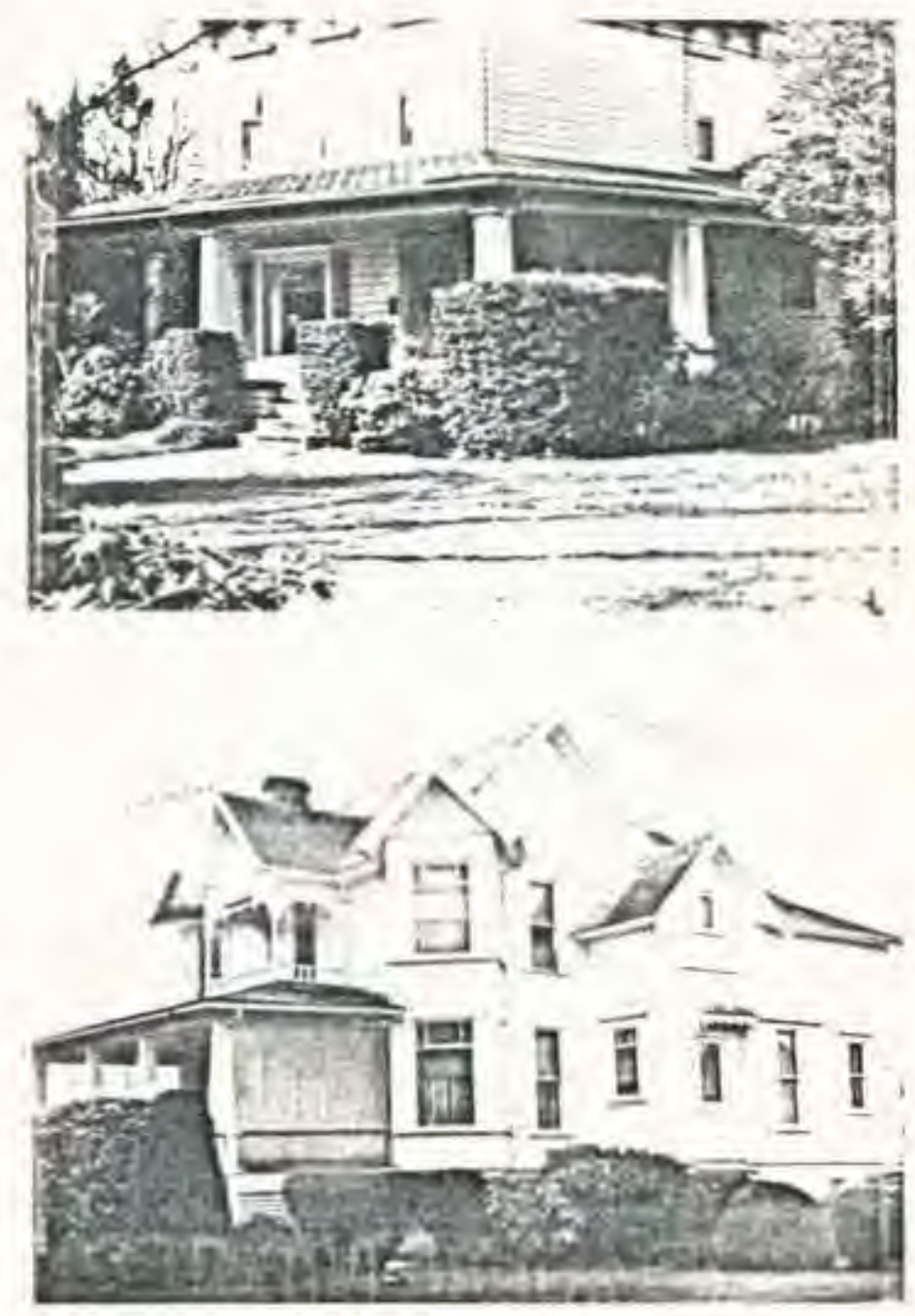

Figure 41. The Thomas Turner House, built in 1883 , and the 0 . 0 . Hodson House, buile before 1899 . 
Register which announced Hodson's completion of a "very attractive addition to his residence in the way of a large porch, $" 180$

A closing observation regarding the prevalence of mission furniture in McMinnville bungalows must be made. The chair in Figure 42 was among the original furnishings purchased for James H. Gibson's bungalow in 1922. The

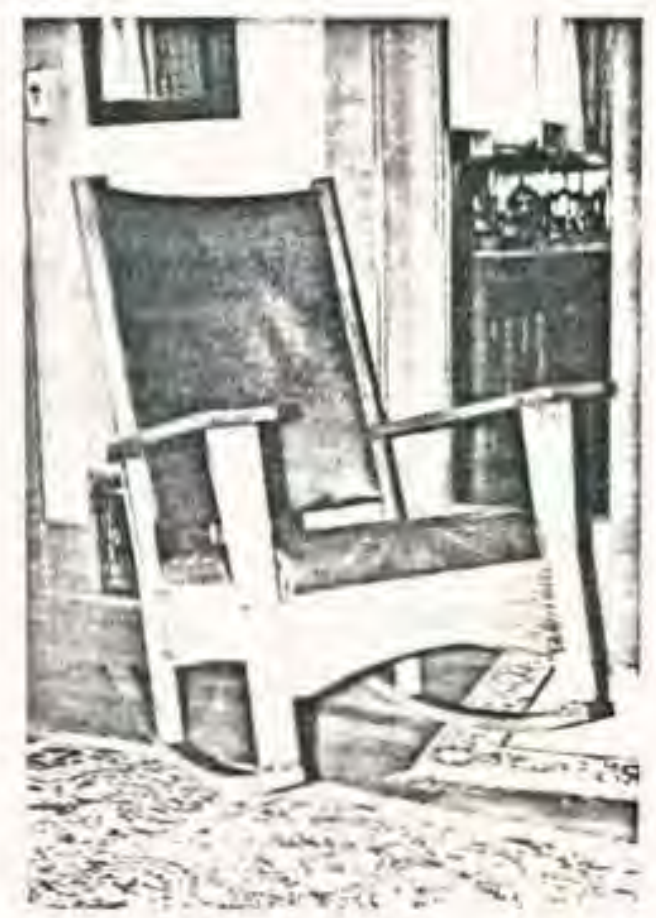

Figure 42. Chair in the James H. Gibson House.

Cooks' foster daughter described square, leather-upholstered davenport, chairs, and settee which she remembered in the Cooks' house, and Frank Wortman's daughter recalled that her mother had furnished their bungalow with mission oak, 81 She

${ }^{80}$ The Telephone Register, April 8, 1910, p. 6.

81 Interviews with Willetta Leever Dow: Dorothy Wortman Gunness . 
wrote in her history that no home was complete without a Morris chair. ${ }^{82}$ A 1910 item in the Telephone Register reported that the Commercial $\mathrm{Club}$ had installed new fumiture made in the "massive mission style--very nicely upholstered,"83 Advertisements in the McMinnville newspapers showed mission furniture in local furniture stores throughout the bungalow period. 84

The foregoing case studies have served to illustrate that the bungalow style of domestic architecture was embraced not only by people of modest means in McMinnville, but also by those whose substance permitted them to build relatively expensive homes. They were fashioned by carpenters who speculated in economical dwellings, and by builders who could work in far more complex construction. Many of them appeared to have been inspired by mail-order plan books and popular magazines.

${ }^{82}$ Gunness, So This Is What We're Made Of: ${ }^{83}$ The Telephone Register, February 18, 1910, p. 6. 84 See The Telephone Register, April 26, 1912, p, 2; August $6,1909, \mathrm{P}, 7$. 
CHAPTER VI

CONCLUSION

The bungalow aesthetic was giving way to new design ideas by 1925. Fenner's 1924 catalogue showed only four bungalows out of twenty-one designs. In 1926, a plan book published by a group of Portland, Oregon building industry officials featured none. Nor were there bungalows in the Architects' Small House Service publication of 1929.1 Ten years later, the bungalow had fallen into disfavor. Emily Post, Alice Wambaugh, and Rexford Newcomb found it ugly, 2 During its heyday, however, the bungalow had found its way into virtually every part of the United States. From 1905 until 1920, the bungalow was middle-class America's style of house.

Isee Fenner Homes of Distinction; Universal Plan Service, Portland Homes, (Portland, Oregon: Columban Press, 1926): Robert I. Jones, ed., Small Homes of Architectural Distinction: A Book of Suggested Plans Designed by the Architects 'Small House Service Bureau (New Yorki Harper and Brothers Publishers, 1929).

2See Emily Post, The Personality of a House, rev. ed. (New York; Funk and Wagnalls, 1933), P. 45; Rexford Newcomb and William Foster, Home Architecture: A Textbook for Schools and Colleges: A Manual for the Home Builder and Home Owner (New York: John Wiley and Sons, 1932), p. 3I; Alice Waugh, Planning the Litcle House (New York: McGrawHill Book Company, 1939), Pp, 3, 189. 
At the time of the bungalow's rise in popularity, technological advances threatened community stability, and the New Woman was seeking equality and freedom from the timehonored doctrine of two spheres. Concurrently, architectural philosophy had evolved through the modes of the Victorian era such as the Queen Anne and neo-colonial styles into new concepts which produced the Prairie School and the Arts and Crafts Movement. American technology, the Arts and Crafts aesthetic, and foreign and historical influences all combined to point the way toward a new house for the middle class and that house was the bungalow.

This study was begun as an attempt to discover if the bungalow emerged because it answered new needs brought about by social changes. The built environment must relate to the people who inhabit it, and bungalow popularity was such a widespread phenomenon that it prompted this investigation to discover why. The purpose here was to draw parallels between nationwide bungalow popularity and the proliferation of the bungalow in one small town. McMinnville, Oregon, in order to draw conclusions about the bungalow in McMinnvilie which would apply to the bungalow in general,

The initial broad investigation of the bungalow as a nationwide phenomenon revealed that it responded to the Atts and Crafts aesthetic which sought to simplify design, and that it met the requirements of changing life styles by offering more convenience and efficiency as the woman moved 
out of the home. These factors were not go clear in the closer study of the bungalow phenomenon in McMinnville,

It appeared that Iittle thought was given to the way a family would utilize a floor plan when a new house was chosen, but a few interviewees believed that women were instrumental in making decisions about room arrangement. A Telephone Register item which reported a bridal shower where guests drew floor plans for the bride's house indicated that women had ideas about plans, ${ }^{3}$ Two interviewees, however, both young women in their twenties when the bungalow style was at its height, did not recall giving much thought to the design of their houses. ${ }^{4}$ Most agreed that the open floor plan of the bungalow afforded more time for the family to be together, whether or not it had been chosen for that reason,

The bungalow-style house had been praised in women's magazines as a house which could be cared for without servants, and in McMinnville this could well have been a factor in its popularity, for only three of all the interviewees recalled that they or their mothers had domestic help during the period under study. Running water, baths, and efficient kitchens eased household chores and increased leisure time. ${ }^{5}$

${ }^{3}$ The Telephone Register. February 11, 1910, p. 5.

Interviews with Nina Miller; Edna Hodson Stanard.

5 Interviews with Dorothy Wortman Gunness, Ogden Cameron, Letha Apperson, Mina Redmond. 
When asked specifically for reasons for building bungalows, all the interviewees agreed that they were inexpensive. One mentioned cheap lumber and labor; another the ease with which small bungalows could be constructed; and another the fact that carpenters tended to use fewer structural members when building speculative houses. 6

Life styles were changing when the bungalow style emerged, and there was some indieation among the interviewees that this shift related to their houses. One man whose parents had a very large family thought they had chosen their bungalow-style house because it had more bedrooms than their former home. A woman interviewee remembered that when her family moved from their two-story Italianate house which had tall narrow windows, her father's chief desire was to sit in his living room and look out the picture window; he had been the one to choose a bungalow plan for their new home, 7

The Indications are that the most compelling factor to influence people's choice of the bungalow was that architecture was fashion and fashion was promulgated by magazines, plan books, and builders. The choice of natural woodwork was not necessarily the result of admiration for the handwrought or well-crafted. The use of Craftsman-inspired

6Interviews with Nina Miller, Ruth Bickford McCall, Aleen Jacobs Fowler.

7 Interviews with Ogden Cameron, Mina Redmond, Evelyn Gibson DeGordin. 
furniture probably had nothing to do with Gustav Stickley's socialist philosophy. H. Allen Brooks concluded that people who bought the new, innovative houses designed by the Prairie School architects who worked in the mode introduced by Frank Lloyd Wright were "largely unaware of what they were getting in terms of architecture,"8 Similarly, a search for social implications in the bungalow style's popularity in McMinnvilie, Oregon reveals that people who built in the genre were not conscious of its social significance. Most interviewees who had lived in bungalow-scyle houses when they were new recalled that fashion dictated house plans, The wife of a prominent builder who had traveled widely recognized the bungalow style as a national trend; she thought it was a contrast to the plain farmhouse. The daughter of a pharmacist who had moved his family out of a lovely, large Queen Anne house to erect a new half-timbered stucco home in 1912 recalled that an architect had convinced the family to build a new house; her mother liked-cubbyholes, she said, and the house plans for the new structure featured many nooks. An interviewee who had not lived in a bungalowstyle house herself but remembered that many such houses were being built between 1910 and 1920 , thought the fashion caught on because it was new. Another whose sister had built a bungalow-style house in 1910 said that house styles changed "just like clothes." A former electrician whose

$$
8 \text { Brooks, p. } 25 .
$$


brother had built many bungalow-style houses recalled that prospective owners usually acquired a set of plans which reflected the current style. A builder who had worked with Dwight Miller said that people bought plans from magazines and lumber companies. People wanted to build houses like their friends' houses, he said, and he recalled that during the years he was building. styles such as the bungalow, the one and one-half story bungalow, and the Cape Cod, came and went, 9 Certainiy it was style and not social or cultural change which prompted the Southern Pacific Railroad to report in the Telephone Register that their new McMinnville depot would be "of the bungalow type and built of brick and concrete." 10

Magazines, as pointed out earlier, played a major role in promulgating the bungalow style nationally, and theit influence was felt in McMinnville as well. The Ladies' Home Journal was available in the public library at least as early as 1911, for earliest library records show that magazines were purchased. An item in the local newspaper reported that library users were asking for the Ladies' Home Journal and that donations of back issues were needed.11

9Interviews with Nina Miller; Zonweiss Rogers Mead, Mina Redmond; Esther Hamblin DeHaven; Howard Miller; Cletus Gill.

10The Telephone Register, March 8, 1912, p. 1.

11McMinnville Public Library, "Library Expenditures," (McMinnville, Oregon, 1911-1912), pp. 3, 7; Telephone Register, June $30,1911, p, 1$. 
The school superintendent that year acknowledged wide Ladies' Home Journal readership in the community when he referred to Bdward Bok's criticism of the public schools in a speech given at the opening of McMinnville's new high school in 1911.12 There are countless examples of bungalow-style houses throughout the pages of the Journal during the period under study which bear marked resemblance to bungalows found in McMinnville, And there was bungalow promulgation closer to home as well. Anybody's Magazine published in Eugene, Oregon featured articles extolling the advantages of bungalow houses and the McMinnville News Reporter ran advertisements with headlines such as, "Buy a Bungalow."13

It was shown in Chapters I and II that historians and architectural critics have found connections between certain social, artistic, and philosophical shifts and architectural development. That a relationship exists is beyond question, The evidence provided by studying McMinnville, Oregon suggests that individually, people whose major concerns were the daily, practical problems of living and working, were not directly influenced in their choice of architectural style during the bungalow era by factors other than fashion, convenience, and availability.

12 The Telephone Register, January 27,1911, p. 1.

13 Anybody's Magazine. Midsummer, 1910, pp. 1, 24; Spring, 1911, Pp, 12, 18, 23; The News Reporter. September 15, 1921, p, 4 . 
It is also true that all the McMinnville bungalow owners moved into their bungalows from two-story homes with traditional closed-room floor plans; and it is true that the bungalows afforded far more convenience than their former houses. Bungalows were built in McMinnville through a series of singular decisions. They were not imposed on the community by one or even several large developers. Those people who testified to buying the bungalows for their economy, style, or availability also affirmed the claims of plan books and magazines that the houses offered comfort, efficiency and space for the gathering together of the family.

The remaining evidence, the houses themselves, suggests that even if the primary motivation in choosing bungalows was fashion, the motivation for continuing to live in them was that they did meet peoples' needs. The architects, the artisans, and the builders designed, built, and sold a house which was immensely well-suited to the American family's requirements. The fact that many of these houses have continued to serve in essentially their original form For nearly seventy years suggests that their innovative floor plans and expressive wooden exteriors have continued to serve and to please. The bungalow was an immensely successful development in the history of American housing. 


\section{SOURCES CONSULTED}

\section{SECONDARY WORKS}

Allen, Edith Louise. American Housing As Affected By Social and Economic Conditions, Peoria, III.: The Manual Ares Press, 1930.

Blumenson, John J. -G. Identifying American Architecture A Pictorial Guide to Styles and Terms 1600-1945. Nashville: American Association for State and Local History, 1977.

Brooks, H. Allen. The Prairie School: Frank Lloyd Wright and His Midwest Contemporaries. New York: W. W. Norton and Company. Inc., 1972.

Brown, Milton W, i Hunter, Sam; Jacobus, John; Rosenblum, Naomi; and Sokol, David M, American Art: Painting, Sculpture, Architecture, Decorative Arts, Photography. New York: Harry $\mathbb{N}$, Abrams, Inc., 1979.

Current, Karen and Current, William R. Greene and Greene: Architects in the Residential Style, Fort Worth: Amon Carter Museum of Western Art. 1974.

Degler, Carl N. At Odds: Women and the Family in America from the Revolution to the Present, New York: oxford University Press, 1980.

Dykstra, Robert. The Cattle Towns, New York: Alfred A, Knopf, 1968.

Glassie, Henry, Folk Housing in Middle Virginia. Knoxville: University of Tennessee Press, 1975.

Gunness, Dorothy Wortman. So This Is What We're Made Of: McMinnville, Ore.; Oregon Lithoprint, Inc., 1967.

Handlin, David, The American Home: Architecture and Society, 1815-1915. Boston: Lietle, Brown and Company, 1979 .

Hitchcock, Henry-Russe11. Architecture: Nineteenth and Twentieth Centuries, Baltimore: Pelican Books, 1958 . 
Holden, Arthur C. American Country Houses of Today. New York: Architecture Book Publishing Company, 1930.

Iones, Robert T., ed. Small Homes of Architectural Distinetion: A Book of Suggested Plans Designed By the Architects' Small House Service Bureau. New York, Harper and Brothers Publishers, 1929.

Xornwolf, James D, M. H. Baillie Scott and the Arts and Crafts Movement. Baltimore and London: Johns Hopkins Press, 1972 .

Lancaster, Clay. The Japanese Influence in America.

New York: Walton H. Rawls; printed in Japan by Book Craft, Ine, 1963.

Lynes, Russell. The Tastemakers. New York: Grosset and Dunlop, The University Library, 1954.

McCoy, Esther. Five California Architects. New York: Praeger Publishers, Inc, 1975.

MeMinnville Association of the Arts: Yamhill County Historical Society; Women's Garden Club; and Men's Garden Club. Historle Home Tour. MeMinnville, Ore. n. P.. 1975 .

Neilson, William Allan, ed. Webster's New International Dictionary of the Engl1sh Language. 2nd ed, Springfield, Mass.: G, and C. Merriam Company. Publishers, 1959.

Newcomb, Rexford and Foster, William A. Home Architecture: A Textbook for Schools and Colleges A Manual for the Home Builder and Home Owner. New York: John Wiley and Sons, Inc., 1932.

Onions, C. I, ed, The Oxford Dictionary of English Etymology. Oxford: Clarendon Press, 1966; reprint ed., 1978 .

Paulus, Norma, comp, Oregon Blue Book. Salem, Ore, : Daily Joumal of Commerce for the State Printing Department. 1979.

Post, Emily. The Personalicy of a House. Revised ed. New York: Funk and Wagnalls Company, 1933.

Sanders, Barry, ed. The Craftsman: An Anthology. Santa Barbara: Peregrine Smith, Inc., 1978.

Saylor, Henry H, Dictionary of Architecture, New York: John Wiley and Sons, Inc., 1952. 
Scully, Mincent, Jr. Modern Architecture: The Architecture of Democracy. New York: George Braziller, 1966.

Waugh, Alice. Planning the Little House. New York: McGrawHill Book Company, Inc.. 1939.

Whiffen, Marcus, American Architecture Since 1780: A Guide to the Styles. Cambridge, Mass;: The M. I. I. Press, 1969.

Wiebe, Robert H. The Search for Order: 1877-1920. New York: Hill and Wang, 1967 .

\section{CONTEMPORARY WORKS}

Architectural League of the Pacific Coast and The Portland Architectural Club. Catalogue of the Fifth Exhibition of the Portland Architectural Club. Portland, Ore. Irwin Hodson Company, 1913.

Boyd, Charles Vaughn, comp. The Little Book of Bungalows and Cottages. New York; The Woman's Home Companion, 1921 .

Carey, Charles Henry, History of Oregon, 3 vols. Chicago and Portland, Ore, Pioneer Historical Publishing Company, 1922 .

Catalogue of the Art Room in the Oregon Buflding at Panama Pacific International Exposition, San Francisco, California. Portland, Ore.1 F. W. Baltes and Company, 1915.

Clark, Robert Carlton. History of the Willamette Valley, Oregon. 3 vols. Chicago: S, J, Clarke Publishing Company, 1927.

Downing, A. J. The Architecture of Country Houses. Introduction by J. Stewart Joknson. New York: Dover Publications, Inc., 1969.

Dustman, U. M. Construction of Dwelling Houses and Bungalows. Chicago: Charles C. Thompson Company, 1913.

Embury, Aymar, II. American Country Houses of Today: Chiefly for Moderate Incomes. New York: Architectural Book Publishing Company, 1917.

- One Hundred Country Houses. New York: Century Company, 1909 . 
Gaston, Joseph. The Centennial History of Oregon: 18111912. 4 vols. Chicago 5 , J. Clarke Publishing Company, 1912.

Hebert, William. Houses for Town and Country. New York: Duffield and Company, 1907 .

Hodgson, Fred T. Practical Bungalows and Cottages for Town and Country. Chicago: Frederick J. Drake and Company. 1906 .

The Practical Cabinet Maker and Furniture Designer's Assistant. Chicago: Frederick J; Drake and Company, Publishers, 1910.

Ring, F, H. Ventilation for Dwellings, Rural Schools and Stables. Madison, Wis, F. H. King, 1908.

Loring, Charles G., ed. The House Beautiful Building Annua1, 1925. Boston; Atlantic Monthly Company, 1924.

McMinnvilie Chamber of Commerce, Yamhill County Oregon: One of the Highly Favored Sections of the Pacific Northwest. McMinnville, Ore, : Telephone Register for the Chamber of Commerce, n. d.

Oregon and Washington State Gazetteer and Business Directory: Seattle: R. I. Polk and Company, $1905-1922$.

Parks, Fanny. Wanderings of a Pilgrim in Search of the Picturesque. 2 vols, London: Pelham Richardson, 23, Cornhill, 1850; historical reprint, Karachi: Oxford University Press, 1975.

Polk's Yamhill and Washington Counties Directory. 2 vols. Portland, Ore.: R, L. Polk and Company, 1912-13.

Popular Mechanics Company, Mission Furniture; How to Make It. 3 vols, Chicago: Popular Mechanies Company, 1909-1912.

Portland Architectural Club. Portland Architectural Club Yearbook 1910. Portland, Ore.; Irwin-Hodson Company, 1910.

Portland Art Association and Portland Architectural Club. Yearbook: Second Annual Exhibition. Portland, Ore.. Irwin-Hodson Company, 1909 .

Portland City Directory, Portland, Ore, = R, L. Polk and Company, 1905-1944. 
Price, C. Matlack. The Practical Book of Architecture. Philadelphia and Londons Lippincott. 1916.

Radford, William A., ed. Radford's Cyclopedia of Construetion. 10 vols. Chicago; Radford Architectural Company, 1923.

Saylor, Henry H. Bungalows: Their Design, Construction and Furnishings, With Suggestions Also for Camps, Summer Homes and Cottages of Similar Character. 4 th ed. New York: Robert M. McBride and Company, 1926.

Starbuck, R. M. Questions and Answers on the Practice and Theory of Sanitary Plumbing. Hartford, Conn, = SmithLinsley Company, Printers, 1904.

W1 Ison, Henry L. The Bungalow Book: A Short Sketch of the Evolucion of the Bungalow From Its Primitive Crudeness to Its Present State of Artistic Beauty and Cozy Convenience. Chicago: Henry L. Wilson, 1910.

Yamhill County Federation of Community Clubs, Yamhill County Oregon, n. p., 1922.

\section{CONTEMPORARY PLAN BOOKS AND CATALOGUES}

The Aladdin Company, Aladdin Homes: "Built in a Day," Cacalogue No. 32. Bay City, Mich : Aladdin Company. 1919.

The Bungalow Book Publishing Company. The Craftsman Book of Bungalows. Portland, Ore, 1 The Bungalow Book Publisting Company, n. d.

The Bungalow Plan Company. The Bungalow Plan Book. Los Angeles: The Bungalow Plan Company, 1908.

Fenner Manufacturing Company. Fenner Homes of Distinction Portland, Ore.: Fenner Manufacturing Company, 1924.

Gordon-Van Tine Company. Gordon-Van Tine's Grand Book of Plans for Everybody. Davenport, Ta.: Gordon-Van Tine Company, n. d.

Keith, Max, comp, Bungalows and Cottages. Minneapolis: Max Keith, n. d.

Ladies' Home Journal. Journal Bungalows. Philadelphia: Curtis Publishing Company, 1921. 
Lindstrom and Almars, Bungalows, Minneapolis: Lindstrom and Almars, n. d.

Los Angeles Investment Company. Inexpensive Bungalows: Typical California Homes, 8th ed, Los Angeles: George Rice and Sons, I912.

- Practical Bungalows of Southern California. 9th ed, Los Angeles: George Rice and Sons, $n$, d.

The Radford Architectural Company, Radford's Artistic Bungalows, Chicago; The Radford Architectural Company, 1908.

Schroeder, Joseph J., Jr, ed. Sears, Roebuck and Company 1908 Catalogue No. 117. Chicago: Follett Publishing Company, 1908; reprint ed., Chicago: The Gun Digest Company, 1969 .

Universal Plan Service, Portland Homes. Portland, Ore. I Columban Press, 1926.

Yoho, Jud, Craftsman Bungalows: Edition Deluxe: A Collection of the Latest Designs. Seattle: Jud Yoho, 1914.

\section{ARTICLES, NEWSPAPERS, AND PERIODICALS}

Anybody's Magazine. Eugene, Ore., midsummer, 1910: Spring. 1911.

The Craftsman, 1905-1916:

The (McMinnville, Ore.) Daily Reporter, 1887.

The Delineator, June-August, 1910.

Good Housekēeping, January-October, 1908: January-March. 1914.

Hibbard, Don J. "Domestic Architecture in Boise, 1904-1912: A Study in Styles." Idaho Yesterdays: The Quarterly Jourmal of the Idaho Historical Society. Fall, 1978 . pp. $2-18$.

House Beautiful, June, 1914.

Ladies' Home Journal, 1905-1916. 
Lancaster, Clay, "The American Bungalow," The Art Bulletin: A Quarterly Published by the College Art Association of America, September, 1958, PP, 239-253.

Lazear, M. H. "The Evolution of the Bungalow." House Beautiful, June, 1914, PP. 2-5.

The (McMinnville, Ore.) News Reporter, 1920-1922.

The Oregon Journal, October 25, 1925; October 23, 1919.

The Portland Telegram, January 4, 1921; October 23, 1919 .

The (Portland) Oregonian, October 23, I920; May 3, 1920; October 26, 1919.

Seattle Post-Intelligencer, January 17, 1981, sec, C, P. 3.

The (McMinnville, Ore.) Telephone Register, 1899-1914.

The (McMinnville, Ore.) West Side Telephone, 1888.

The Yamhill County Reporter, 1900-1903.

DOCUMENTS, MANUSCRIPTS, AND MISCELLANEOUS SOURCES

Apperson, Letha C. Photograph Collection. McMinnville, Oregon.

"The BungaIow Age." EXHIBIT. Eugene, Ore., Lane County Pioneer Museum. September, 1980.

Cameron, Ogden. Photograph Collection. McMinnville, Oregon.

DeGordin, Evelyn Gibson. Photograph Collection. McMinnville, Oregon.

Derby, V. L. BLUEPRINTS. 5 sheets. McMinnville, Oregon, n, d,

Druse, June. Photograph Collection. McMinnville, Oregon.

Gibson, Julia Etta Cumins. "Cummins Family History." TYPESCRIPT. McMinnville, Ore.. 1954.

Ore., "The Gist.

Larry, E, N, "Residence for Mr. Frank Rogers." BLUEPRINTS, 7 sheets. McMinnville, Ore,, 1912. 
Lievrance, Iva G. "P1an No. 103." BLUEPRINTS, 3 sheets. n. p.., n. d.

Maloney, H. S. "City of McMinnville, Oregon, 1902." MAP McMinnville, Ore., 1902,

McMinnville, Oregon, City Council. Minute Books. McMinnville, Oregon, 1876-1915.

McMinnville Board of Trade. "Minute Book," McMinnville, Oregon, 1903.

McMinnville Planning Department and Oregon State Historic Preservation Office. "McMinnville Historic Resource Inventory: Phase I." 3 vols. McMinnville, Ore.. , 1980 .

MeMinnville Public Library. "McMinnville Public Library: Library Expenditures." MeMinnvilie, Ore., 1911-1912.

National Builders' Bureau. "907." BLUEPRINTS. Spokane, n. d.

The National Union Catalog: Pre-1956 Imprints. 705 vols. London: Mansell Information/Publishing Limited, 1968 .

"The Pendleton Family," TYPESCRIPT, McMinnville, Ore, n.d.

Rees, Judith and Weingrod, Carmi, "The Bungalow Age," SLIDE-TAPE SHOW. Eugene, Ore., September, 1980.

Sanborn Map Company, "MeMinnville, Yamhill Councy, Oregon." MAPS. New York: Sanborn Map Company, 1912, 1928.

Shotwell, Arleta Loop. Photograph Collection. McMinnville, Oregon.

Title and Trust Company. "Abstract of Title No. 4954." Portland, Ore., 1950.

Title and Trust Company. Yamhill County Branch. "Abstract of Title No. 2168." McMinnville, Ore., 1949.

United States Bureau of the Census. Census of the Population: 1970. vol. 1. Characteristics of the Population: Part 39, Oregon, Washington, D, C.: U. S. Government Printing Office, 1973.

United States Housing Corporation. Report of the United States Housing Corporation. 2 vols. Washington, D. C.: U. S. Government Printing Office, 1919-1920. 
Yamilil County. County Commissioners" Journals, 25 vols. LafayetedMcMinnville, Ore., 1857-1941. Vo1. 9.

Yamhill County. Deed Records. 214 vols., 159 films. Lafayette/McMinnville, Ore., 1865-present.

Yamhill County. Tax Rolls. MICROFORMS. McMinnville, Ore, , 1947-present.

\section{INTERVIEWS}

Apperson, Letha C. Interview. McMinnville, Oregon. February 16, 1981.

Blenkinsop, Richard. Interview, McMinnville, Oregon. January 15, 1981.

Bynum, Velton. Telephone interview. February 1, 1981.

Cameron, Ogden. Interview. McMinnville, Oregon. February 25, 1981.

DeGordin, Evelyn Gibson. Interview, McMinnville, Oregon. January 14, 1981 .

Delaven, Esther Hamblin. Interview. McMinnville, Oregon. March 2, 1981.

Dillin, Harry Leslie. Former president, Linfleld College. McMinnville, Oregon. February 3, 1981.

Dow, Willetta Leever. Interview, Portland, Oregon. February 4, 1981.

Downing, Frances. Assistant professor, Department of Architecture, State University of New York at Buffalo. Interview. Portland, Oregon. January 5, 1981.

Ellis, Effie, Interview. McMinnuille, Oregon. March 7, 1981.

Fowler, Aleen Jacobs, Telephone interview. March 22, 1981.

Gerber, Mary Frances Mulkey. Telephone interview. January $28,1981$.

Gi11, Cletus. Telephone interview. February 17, 1981.

Gould, Sigrid. Interview. McMinnville, Oregon. March 20. 1981 . 
Gunness, Dorothy Wortman. Interview. McMinnville, Oregon, February 24, 1981.

Holland, Alice McCune. Telephone incerview. February 1. 1981 .

McCal1, Ruth Bickford. Interview. McMinnville, Oregon. January $15,1981$.

Mead, Zonweiss Rogers. Interview. McMinnville, Oregon. February 23, 1981.

Miller, Howard. Interview. McMinnville, Oregon, January $26,1981$.

Miller, Nina Brown. Interview. Milwaukie, Oregon. January 28, 1981.

Ode11, Floyd A. Interview. McMinnville, Oregon. January $23,1981$.

Ode11, Madeline. Interview. Mckinnville, Oregon. February 18, 1981.

Odel1, H, William. Interview, McMinnville, Oregon. February 18, 1981.

Redmond, Mina Jean. Interview. McMinnville, Oregon. February 23, 1981.

Shotwell, Arleta Loop. Interview. McMinnville, Oregon. March 3, 1981.

Stanard, Edna Hodson. Interview. McMinnville, Oregon. February 3, 1981.

Wheeler, Lauretta. Interview. McMinnville, Oregon, February 18, 1981،

Wheeler, Marguerite, Interview. McMinnville, Oregon. February 18, 1981. 